E.

\title{
GENERALE NEDERLANDSCHE GEOCTROYEERDE OOST-INDISCHE COMPAGNIE
}

1602-1800. 


\section{BANTAM.}

1603. 1

De eerste vloot, welke na de oprichting der groote Oost-Indische Compagnie uit Nederland koers zette naar Oost-Indië, stond onder bevel van Wijbrand van Waerwijek als admiraal en Sebald de Weert als viceadmiraal. Een deel der schepen onder bevel van den vlootvoogd zelf kwam na een zeer lange reis den 29 April 1603 bij Bantam aan. Hij sloot hier een overeenkomst ten opzichte der tollen en rechten, waarvan een korte inhoud hier volgt. (Vgl. De Jònge, Opkomst, III, bldz. 20).

Is bij den admirael Warwijk met die van Bantam verdragen en geaccordeert, datt voor jeder schip robbe robbe ${ }^{2}$ sall betaelt worden 750 ra van aghten, doch den Sabandar stryckt ten onreghte daervan $\frac{1}{3}$ nae hem, gevende den Koningh de resterende $\frac{2}{3}$.

Dat voor yder schip billibilan ${ }^{3}$ zall betaelt worden $666 \frac{2}{3}$ ra van aghten offte 2000 sacken over 3 schepen, een ra meer als men van de gemeente koopt, 't'welck zij zeggen, dat een oudt reght dezes konings is. Men avanceert hier maer voor een schip en als dat geladen is, betaelt men weder voor een ander. t Is voor elck schip in alles $1416 \frac{2}{3}$ ra van aghten 4 behalven alle ordinarische tollen en andere kleyne ongelden, ende bovendien nogh eenige geschenken, zoo aen den Koningh, als den Gouvern ${ }^{\mathrm{r}}{ }^{5}$. Maer die van Bantam hebben daer nae nogh billibilan willen reeekenen voor het geene d'onse over de 18000 sacken in drie schepen geladen hebben, allegerende, dat de twee eerste schepen niet hooger als op 6000 zacken jder aengegeven waren ende alhoewell het accoordt duydelijck op de scheepen ende niet op het getall der zacken gemaeckt was, moest Warwijck niet te min aen den Koningh nogh 130 ra en 10 rosenobels ${ }^{6}$ toewerpen voor 4500 sacken peper, die over de voornoemde 18000 zacken daer ingeladen waren. ${ }^{7}$

1 Uit het Contractboek. - Het exemplaar in 's Lands archief te Batavia heeft de nadere tijdsbepaling: Mei 1603.

${ }^{2}$ Roeba roeba.

3 Běli-bělian = koopwaren, dingen die men koopt of gekocht heeft. Hier blijkbaar een tol of recognitie.

4 Tiele, Europeërs, VI, bladz. 74, zegt niet geheel juist: 1500 realen.

5 De toenmalige Nederlandsche benaming voor den Rijksbestuurder.

6 Engelsche gouden munt ter waarde van ongeveer f 12 .

7 Het laatste gedeelte der beide alinea's behoort natuurlijk niet meer tot het eigenlijk contract. 


\section{KUST VAN MALABAAR.}

\section{November 1604. 1}

Den 18 December 1603 verliet een sterke vloot ander bevel van Steven van der Haghen patria. Hem was bepaaldelijk opgedragen, vijandelijk tegen de Spaansch-Portugeesche macht in het Oosten op te treden, ook aan Voor-Indië's kusten, en tevens, om verdragen van bondgenootschap met de vorsten dáár te sluiten. Den 29sten October 1604 kwam Van der Haghen bij Calicut aan, de residentie van het rijk van den Sāmundri of "Samorijn" (Zamorin), zooals de Nederlanders hem noemden. Deze vorst was in vijandschap met de Portugeezen en het kostte Van der Haghen weinig moeite, hier aan de opdracht tot het sluiten van een verbond te voldoen. (Vgl. De Jonge, Opkomst, III, bldz. 9, 26-34; Tiele, Europeërs, VII, bladz. 84-85).

Accoordt gemaakt tusschen den doorlughtigen Samorijn, keijzer van Malabaer, ${ }^{2}$ ende den E. heer admiraell Steven van der Hagen van wegen de Ed $^{\text {en }}$ Mogende Heeren Staten Generaell ende sijn princelijke $\mathrm{Ex}^{\mathrm{e}}$ Mauritius etca. $160411^{\mathrm{e}} 9 \mathrm{ber}$.

Allen ende een jgelijcken die desen sullen sien offte hooren leezen saluijt.

Wij Steven van der Hagen van wegen de Eden Mogende Heeren Staten Generaell der Vereenighde Provintien, ende sijne Ex ${ }^{\mathrm{e}}$ Mauritius prince van Orangie, grave van Nassou, admiraell generaell van de Belgische zee, ${ }^{3}$ admirael over 12 schepen, doen kond dat wij door de goede vrindtschap, ons van den mogenden keijser ende sammorijn van Malabaer bejegent, ook mede door de voornoemde heeren expresse belastingh, hebben na goede rijpe deliberatie ter eeren Godes en tot opbouwingh beijder rijcken gemaeckt ende jngegaen een vast verbondt, eeuwige ende onverbreeckelijcke alliantie tot verdruckingh der Portugesen, ende alle hare geassocieerde, haer te verdrijven uyt alle de landen van Sijne Mayesteijt en ook uijt geheell Indien; ende dat met de naeste gelegentheijt schepen en volck sall gesonden en tot Calicoutt te handelen ende koopluijden tot dien eijnde daer houden residerende, omme het welcke te effectueeren op de beste gelegentheit een fortresse zall worden gebouwt, die in handen ende gebiedt van onse natie altijtd sall blijven. Ook

1 Uit het Contractboek.

2 Op dezen titel valt heel wat af te dingen met het oog op de werkelijke toestanden.

${ }^{3}$ Een toespeling op den titel Sāmundri (= beheerscher der zee, zee-koning)? (Vgl. Hobson-Jobson, p. 745; Zinadim-Lopes, Malabar, p. LXII, s.). 
mede tusschen beijde de natien expresselijck gestupeleerd, reciproquelijck geen vrede met de Portugesen te mogen maeken, voor en all eer de een den anderen daervan eerst well en light (?) verwittight te hebben; ende daerover hem beswaert vindende, den anderen geensints geene contracten van vreede zall mogen jngaen. Ook dat alle die van de cust van Mallabaer, beginnende besuyden Goa tot de Cabo de Camorijn, 1 niet sullen vermogen eenige navigatiën te aenvaerden sonder paspoort van den Samorijn daertoe ontfangen te hebben, offte daer over geattrappeerdt zijnde, voor goeden buijt ende prince sullen gehouden ende verklaert worden. Aldus gedaen ende gesloten tot Pembenaer, ${ }^{2}$ den 11ber. 1604 stilo novo. Was geteekent Streven van der Hagen.

\section{AMBON.}

Februari 1605. 3

Steven van der Haghen verliet den 25 Januari 1605. Bantam, om hulp te brengen aan de bewoners van het eiland Ambon tegen de Portugeezen, die na de lichting van ons garnizoentje wraak hadden genomen op de inlanders voor de welwillende ontvangst der Nederlandsche schepen. Den 21 Februari kwam onze vloot bij het eiland aan en zonder slag of stoot ging den $23^{\text {sten }}$ daaraanvolgende het Portugeesche fort op Lei-Timor bij verdrag aan Van der Haghen over. Deze sloot na deze belangrijke gebeurtenis een contract met Hitoe. (Vgl. Tiele, Europeërs, VI, bl. 86-89.)

Accoordt van capiteijn, oock de hooffden van Hitoe ende den admiraell Steven van der Hagen.

\section{Februarij.}

Allsoo de Hollanders met de hulpe Godes, ende den admiraell Steven van der Hagen ende sijnen raedt van de schepen ons verlost heefft uijt de handen van de Portugesen onse vijanden, cap $^{\mathrm{n}}$ Hitoe ende alle de hooffden ${ }^{+}$ende jngezetenen van Hitoe ende

1 Kaap Komorin.

2 Moet gelegen zijn tusschen Calicut en Cochin. (Vgl. De Jonge, III, bladz. 168-176.)

3 Uit het Contractboek.

4 Hitoe werd toen bestuurd door den z.g. kapitein (capitão) Hitoe "met de vier hooffden des landts Hitoe" (Orangkaja ampat). De titel is Portugeesch, maar staat niet in verband met de Portugeesche overheersching van dit Noordelijk deel van Ambon. Misschien is de z.g. kapitein Hitoe oorspronkelijk een soort rijksbestuurder geweest voor den radja, die Hitoe 
alle de steden daer omtrent gelegen, jae datt meer is dat de Hollanders alle onse landen ende steden ons wedergeven en in handen laeten bezitten heefft, om welke weldaet wij cap: Hitoe ende alle de hooffden van Hitoe en d'omleggende steden belooven ende sweeren, de Staten Generaell van de Vereenigde Nederlanden, zijn Princelijcke Ex ${ }^{\text {tie }}$ ende de Gouvern ${ }^{\mathrm{r}}$ van Amboyna gehouw en getrouw [te] zijn, zoolang als wij leven.

$1^{\circ}$.

In den eersten soo sweeren wij hooffden al te samen den Gouvern $^{r}$ te assisteren tegen alle vijanden, die jets tegen hem offte tegens het fordt ${ }^{1}$ zouden willen attenteren te water offte landen.

$2^{\mathrm{e}}$.

Van gelycken zweeren wij voorschreven, dat wij niemandt eenige nagelen zullen verkoopen als aen de Hollanders, ten zij met voorwetten van den Gouvern ${ }^{\mathrm{r}}{ }^{2}$

$3^{\mathrm{e}}$.

Ten anderen zal een ijder leven in zijn geloofft, gelijck hem Godt int herte stiert offte meent zaligh te worden, dogh dat niemandt den anderen zall molestie nogh overlast doen.

$4^{\mathrm{e}}$.

Ende zoo het geviell, dat eenige Hollanders wegh liepen nae Hitoe offte die quartieren, belooven wij den Gouvern ${ }^{\mathrm{r}} \mathrm{t}^{\text {' zijnen }}$ versoecke deselve weder in handen te leveren en off dat oock ijmandt wegh liepe van Hitoe bij het Cassteell ${ }^{3}$, zall den Gouvern ${ }^{r}$ gehouden wesen aen die van Hitoe weder te leveren.

bestuurde, toen de Nederlanders op Ambon kwamen, met de z.g. vier hoofden. (Vgl. Tiele, Bouwstoffen, I, bldz. III.) Maar deze zelfde kapitein Hitoe vertegenwoordigde den sultan van Ternate, die op Hitoe min of meer nominale rechten pretendeerde (Tiele, Europeërs, VI, bldz. 6, 7, 33; Heeres, Bouwstoffen, III, bldz. 205, 206, v., 209, 235). - Deze rechten hadden alle beteekenis echter verloren, sedert de Portugeezen in 1602 Hitoe weder hadden veroverd. (Tiele, Europeërs, VI, bldz. 60). Vgl. nog contract $\mathrm{n}^{\circ}$ VI (waar sprake is behalve van den Kapitein, ook van een "gouverneur") en mijne bijdrage: Ambon in 1647 in deze Bijdragen, XLVI, bldz. 517, v., 539). De radja van Hitoe moet dan echter al spoedig in de $17^{\text {de }}$ eeuw uit het bestuurstelsel zijn verdwenen. (Vgl. b.v. Tiele, Bouwstoffen, I, bldz. 202, maar ook deze Bijdragen, III, bldz. 94 jo 105).

1 Het kasteel Victoria (toen zoo gedoopt) op Lei-Timor.

2 Dit monopolie-artikel vergeet Tiele, en het is toch van zoo hoog belang voor de geschiedenis onzer betrekkingen met de Ambon-eilanden.

s Victoria. 
$5^{\mathrm{e}}$.

Of het geviell, dat de Hollanders, eenigen oorloch doende offte onbehoorlijckheijt, jn de huijsen van de jnwoonders liepen, zall den Gouvern ${ }^{\mathrm{r}}$ gehouden wesen, straffe daerover te doen; ook sullen de jnwoonders niet gehouden wesen de nagelen aen tCasteell te brengen.

$6^{\mathrm{e}}$.

Ende off den Gouvern ${ }^{\mathrm{r}}$ ons tot eenige saeken ${ }^{1}$ dede roepen, zoo zullen gehouden wesen, die van Olisiva aen die van Olijlima ${ }^{2}$ te helpen; van gelijcke die van Olijlijma aen die van Olisiva.

Over welcke belofften soo beloove ick, gouverneur van wegen de Heeren Staten Generael der Vereenigde Provintien ende Sijne Princelijcke Ex ${ }^{\text {tie }}$, Cap ${ }^{\mathrm{e}}$ Hitoe en alle etc ${ }^{\mathrm{a}}$. Hier omtrent ${ }^{3}$ het slott. ${ }^{4}$

\section{AMBON.}

\section{Februari 1605. 5}

Een gedeelte der bewoners van de Ambon-eilanden had de zijde der Portugeezen gehouden; zij legden thans den eed van trouw af aan de Compagnie. (Tiele, Europeërs, VI, bldz. 88). Onder hen het inlandsche hoofd, de patih, van het eiland Oma of Haroekoe.

Ick Steven van der Hagen, generael van deze armade, van wegen de Edele Mog. Heeren Staten der Vereenichde Provincien ende van Syne Excell. graeff Maurits, prince van Oraengien, als admirael ende $\operatorname{cap}^{\mathrm{n}}$ generael te water en te lande, door die E. Mog. heeren Staten Generael, so geve ick pardoen, liberteit en doe verseekeringe aen den coninck van 't eylandt Oma, met alle die inwoonders van

1 Eene andere lezing (die van de vernieuwing van dit contract in 1609, no XXIX) heeft: „wercken".

${ }^{2}$ De Oelilima en de Oelisiva waren de namen der partijschappen, waarin de bewoners der Ambongroep van ouds verdeeld waren, evenals die van Banda. (Zie hiervóór, bldz. 24. Tiele, Bouwstoffen, I, 2, 205, enz. Over de beteekenis dezer namen zie Wilken-Pleyte, Volkenkunde, bldz. 347).

$s$ Ontbreekt?

4 Het slot kan aangevuld worden uit de vernieuwing van dit contract den 9 Augustus 1609. (Zie hierachter $\mathrm{n}^{\circ}$ XXIX.) Het moet dan luiden: „en alle hoofden ende ondersaten van die quartieren te helpen en bijstaen als ons eijgen natie tegen alle haere vijanden".

${ }_{5}^{5}$ Overgenomen uit Archief voor kerkelijke en wereldsche geschiedenissen... uitgegeven ... door J. J. Dodt van Flensburg, IV (1844), bldz. 310. „Naar copij geschreven door Arn. v. Buchell." De datum is daar foutief aangegeven als 25 Februari 1603.

7• Volg. III. 
die stedekens ende vlecken van 't eylandt, wesende hunne vasallen, opdat den voorseyden coninck met syne vasallen mach gerust ende versekert in syn lant wonen, ende dat de Coninck met de synen met onse licentie mach vrielicken gaen ende comen, handelen ende traficqueren aen ons casteel, gelyck als goede getrouwe vasallen van de E. Mo. Heeren Staten Generael; ende alsoo belooven wij van onsent wegen, dat den coninck van Oma met die synen niet en sullen qualicken getracteert worden, noch van de genen, welcke hier ter bewaernisse van dese forteresse sullen blyven, noch van den genen, die namaels van de E. M. Heeren Staten Generael souden mogen gesonden worden, maer ter contrarien so sullen se wel getracteert worden, gefavoriseert ende geholpen worden, gelyck als goede ondersaten tegen allen vyanden, die haerluyden souden, willen offenderen offte misdoen, ende datselve is met alsulcke conditie, dat die coninck van Oma met alle zijne ondersaten gehouden sal wesen, den dienst te doen, die hen den goeverneur van 't casteel ende archipelago van Amboina gebieden sal te doen, d'welck sijn wercken van de fortificatie ende denselven dienst, die hy te voren aen de coningen van Portugal was verobligeert te doen, gelyck als 't wesende siju vasal. Ende in teyken der waerheyt, dat den coninck van Oma 't selve begeert te voldoen, soo sal hij syn eed van getrouwicheyt doen aen die E. M. Heeren Staten Generael ende Syn Excell. graef Maurits, als souvereyne heere van die voorschreven eylanden van den archipelage van Amboina, ende oock mede aen den gouverneur van die forteresse ende den archipelage van Amboina ende in zijn absentie ofte by versterven andere, die in syn plaetze van de E. M. Heeren Staten Generael sullen mogen gesonden ofte geordonneert worden. Ende dese eed sal hy doen in presentie van den admirael van dese armade, Steven van der Hagen, denwelcken hem den eed sal afnemen van wegen die E. M. Heeren Staten Generael, als haren lieutenant ofte stadthouder, in dese quartieren van herwaerts over.

Aldus gedaen in Amboina, den 25. February 1605.

Steven van der Hagen. 


\section{AMBON.}

3 Maart 1605. 1

Steven van der Haghen vertrok 1 April 1605 van Ambon naar Banda. Vooraf had hij Frederik de Houtman benoemd tot gouverneur van Ambon en omliggende eilanden. Een aantal Portugeezen bleven onder de bescherming van het Nederlandsch kasteel op Ambon wonen. (Tiele, Europeërs, VII, bldz. 89 en noot 2). Deze legden den 3 Maart den eed van trouw aan de Compagnie af.

Nos los Portugeses casados y moradores desta ciudad y fortalesa de Amboyno promettemos y juramos en nombre de Nuestro Sen̄or Jesu Christo y sua santos Euangelios que de aqui adelante y para siempre auemos de ser buenos, leales y obedientes vasallos de los Nobiles Poderosos señores Estados Generales de las Prouincias Unidas de Germania la Baxa y a su Exa el Conde Maurisio, principe d Orange, Capitan general de la mar y tierra de los dichos Senores Estados Generales, y tambien a Frederico de Houtman, gouernador desta fortalesa y archipelago de Ambona, como lugarteniente en estas partes de los N. P. S ${ }^{\text {es }}$ Estados Generales, y en su fallissimiento y ausensia al otros gouernadores que en su lugar nos por los N. P. S. sera embiado ho ordenado y tambien que auemos de mantener y ayudar que se mantenga el acorde $y$ articulos de contracto hecho a 23 de Febrero $^{2}$ con el general deste armada Esteuan van der Hagen. Y este auemos de cumplir y haser que se cumple lo qual no dexaremos de haser por nengun miedo ni temor de perder nuestras vidas ni hasiendas. $\mathrm{Y}$ ansi verdaderamente Nuestro Señor Dios Todopoderosa nos quiere guarder de todo mal. Fecha en Ambojno a 3de Marso a de 1605.

Hier volgt de Nederlandsche vertaling van bovenstaande overeenkomst, zonderling genoeg in het Spaansch gesteld.

Wij gehoude ${ }^{3}$ Portegisen, jnwoonders van - die stadt ende forteresse van Ambona, belouen ende sweren jn den namen van onsen Heere Jesu Christus ende syne Heilige Euangelie, dat wij van nu voortaen ende voort eeuwelicken sullen wesen goede loijale obediente

1 Dit afschrift is genomen uit de papieren van Arnold van Buchel, uitgegeven in de Bijdragen en Mededeelingen van het Historisch Genootschap, VI (1883), bldz. 337 , vv.

2 Het verdrag van overgave van het fort Victoria.

3 Gehuwde. 
vassalen van die Edel Mogende Heeren Staten Generael van die Verenichde Provinthien van Neder-Duitsland ende van Sine Ex ${ }^{\mathrm{e}}$ graeff Maurits, prince van Oraengien, Capitein generael te water ende te lande van die E. M. H. Staten Generael, ende oock meede aen Frederick Houtman als, goeverneur van dese forteresse ende archipelago van Ambona als stadthouder vau dit lant voor die E. H. M. Staten Generael, ende jn sijn absentie ende versterven verbonden blijven aen andere goeverneurs, die in sijn plaetse van de E. M. H. Staten Generael ons geordineert ofte gesonden sullen werden. Ende oock mede sullen wy onderhouden, ende hellepen dat onderhouden mogen werden die artikelen vant acoort den $23^{\text {en }}$ Februario met den admirael van deze armade Steuen van der Hagen gemaekt ende dat selue sullen wij nae comen ende maken dattet nagecomen ende volbracht wort. Alle $t$ welcke wij niet na laten sullen, door eenige sorge ofte vrees van te verliesen lijff ofte goet. Also warachtelicken moet ons Godt Almachtich bewaren voor alle quaet.

Gedaen jn Ambona den 3en Martio A $A^{\circ} 1605$.

\section{BANDA.}

$13{ }^{1}$ Juli 1605. ${ }^{2}$

Terwijl Steven van der Haghen nog op Ambon was, vernam hij, dat op Banda eenige Nederlanders waren vermoord (misschien omdat zij een paar hunner landgenooten, welke den Islam hadden aangenomen, in het huis van een Mohammedaansch priester te Neira hadden gedood). De Nederlandsche koopman op Banda, Jacob de Bitter, was geweken naar Loehoe op Klein-Ceram. Van der Haghen vertrok met het oog hierop 1 April 1605 naar Banda, trad in besprek met de inlandsche hoofden en sloot met een aantal hunner een nieuw contract. Niet allen echter traden tot deze overeenkomst toe, n.l. niet Labetaka ${ }^{3}$ en niet Lontor. (Vgl. Tiele, Europeërs VI, bldz: 89, v.; van der Chijs, Banda-eilanden, bldz. 20-28.)

Articulen ende ordonnantie besloten tusschen den $\mathrm{h}^{\mathrm{r}}$ Admir ${ }^{1}$ Steven van der Hagen ende de zijne met de overheijt en principalen van 't landt Banda, te weten met dezen navolgende steden als Neijra, Salamma,

\footnotetext{
1 Vermoedelijk: zie Tiele, t. a. p., bldz. 90 , noot 1.

2 Uit het Contractboek.

3 Labetaka sloot zich kort daarop er bij aan.
} 


\section{Waijer, Ourien, ${ }^{1}$ Dender, Comber, Samber, ${ }^{1}$} Ortatten, met die van eijlanden Poulo Aij ende Poulo Ron, en 't eilandt Rossingeijn, welke navolgende articulen sijn bij partijen bevestight en bedaght nae te komen.

Jn den eersten hebben besloten ende overeengekomen dat een jgelijck van voorschreven partijen, te weten de Hollanders ende Bandanesen, sullen Godt almaghtigh dienen, elck nae de gracie en gave die Godt haer verleent heefft zonder malcanderen om zulcx in eenige manieren in de wege te zijn, te beletten, te haten offte den anderen een quadt herdt toe te dragen, waeruijt dat soude mogen spruijten eenige vijanschap; maer zall d'een den anderen well bejegenen ende voorstaen ende 't rest Gode beveelen.

Item belooven de voorschreven overigheijdt van de steden ende landen Banda de Hollanders, daer opperkoopman van is en overste den eersamen Henderick van Bergell ${ }^{2}$, den selven met de zijne, als Hollanders en andere onder hun staende, behulpzaem te wezen, beschermen voor alle quadt dat haer zoude mogen overkomen, voor alle jnlandtsche ende uijtlandtsche oorlooge ende vijanden, nae goedt vermogen haer voorstaen, gelijck als zij doen souden voor haer eijgen vrouwen en kinderen en in geenderleij manieren consenteren, dat haer van ijmandt eenigh quadt offte overlast zoude worden aengedaen.

Item daer en tegen den Opperkoopman zall met all zijn volck, onder hem staen(de), t'zij Hollanders ende persoonen in zijnen dienst wesende tot Banda, bij aldien dat het zake waere datter eenige vreemde vijanden van buijten quamen om het gemeene landt van Banda te beoorloogen ende destrueeren, datse sullen naer haer vermogen t' landt helpen defenderen, te assisteren met haere middelen, dewelcke Godt Almaghtigh de Hollanders heefft verleent; maer bij aldien off 't zaeke ware datter wederome eenige jnlandtsche oorloge offte twist opstondt tusschen de Bandaneesen onder den anderen, dat de Hollanders haer daermede niet sullen hebben te bemoeijen dan stille sitten, dan well haer best te doen om vrede te maeken.

Item off het zaeke waere dat de opperkoopman, met zijn volck alhier in Banda blijvende, ijmandt van zijn volck ontliepe, zullen

1 Aan de Zuidzijde van het eiland Lontor tusschen Lackoeij en Toetra. (Vgl. Valentijn, Banda, bldz. 10, 35; Tiele-Heeres, Bouwstoffen, II, bldz. 88).

${ }^{2}$ Deze werd in dezen tijd door Van der Haghen als zoodanig aangesteld. 
de Bandanesen niet vermogen, deselve op te houden offte haer in eenige manieren voorstaen, veel $\mathrm{min}$ deselve te trecken tot haer geloove om Moors te maeken offte eenige quellagie aendoen, maer ter contrarie sullen deselve weghloopen(de) wederomme leveren jn handen van haere meessteren die met haere leven zall naer behooren, ende sullen den Oppercoopman laeten geworden adminisstreeren de justitie, want sulcx tot goede discipline ende politie onder zijn volck te onderhouden dient gedaen.

Mede sullen alle de overheijdt van $t$ landt Banda met die van de eijlanden gehouden wesen, alle haere nooten ende foeillie te verkoopen tot all zulcke prijse als men met den anderen zall accoorderen, ende overeen komen, welcke Hollanders makeu zullen, dat die van Banda van alderhande coopmanschappen ende victualie sullen voorsien werden, als ook mede van goudt ende zilver, maer zullen well mogen handelen met andere natien die coopmanschappen brengen haer dienstigh ende die de Hollanders niet en hebben.

Item sullen alle de overheijdt ende inwoonders voorschreven vant landt Banda de Hollanders in haere huyzen tot Neijra, Ortatte ende Salemme, den Admiraell vertrocken wesende naer Hollandt, deselve met alle rust ende vreede laten wonen, ende naderhandt niet moeijelijck vallen, te weten haer coopmanschappen ende goederen voor minder prijs doen verkoopen als de prijse daervan met die vant landt gestelt zijn offte eenige andere quellagie, t'zij om borge offte ander gelt affleenen, daerdoor dat namaels groote questie ende quadt soude uijt reijsen, maer ter contrarie sullen bij ${ }^{1}$ de Hollanders vredelijck laeten koopen ende verkoopen, gelijck als dat behoordt ende de reghte maniere van handelen is.

Alle de voorschreven articulen gelooven ${ }^{2}$ wij, alle de principaelste overigheijdt van de eijlanden Banda ende de Hollanders, den Opperkoopman met de zijnen, aen wederzijden, denselven onverbrekelijck te onderhouden ende doen onderhouden ende wie de geene ware van bijde zijden, t'zij Bandanesen offte Hollanders, die de voorschreven articulen contrarien deselve niet en willen onderhouden ende namaels breken, zullen dezelve overtreders als perturbateurs ende verstoorders van 't gemeene welvaren, de scheepen van Hollandt overkomende, aen de overigheijt van djen werden overgelevert, om gestrafft te worden naar verdienste. Alle de voorschreven artyculen hebben wij

1 Van der Chijs, bldz. 173, heeft: "sy".

"Van der Chijs, bldz. 173, heeft: „belooven". 
partijen met eeden bevestight ende beloofft nae te komen. Zoo waerlijck moet ons Godt helpen. Amen.

Aldus gedaen te Banda int t'schip de Geunieerde Provintien den .... Julij 1605 .

\section{Onderstondt Hendrick Bergell.}

Ik laat hier nog volgen onderstaande lezing van de overeenkomst met Banda. ${ }^{1}$ Misschien is het voorgaande een concept geweest. ( $\mathrm{Vgl}$. nog Van der Chijs, Banda-eilanden, bladz. 26).

Volgen die Arthikelen ende puncten vant acoort, dwelck tusschen den Admirael Steven van der Hagen ende alle ${ }^{2}$ die overicheit ende raden van die eijlanden van Banda gemaeckt sijn ende van weersijden onderteykent.

In den eersten is geacordeert ende besloten te Ortatan ${ }^{3}$ onder den grooten boom, daer van ouds die gewoonte is, die generale vergaderinge te houden, dat die Hollanders ende Bandanesen, een ijegelick van haer luijden, sal sijnen Godt dienen, na die gratie ende gave die haer van den Heere verleent is, sonder malcanderen om sulcx jn eenigerleij wyse pogen te beletten, misseggen ofte een quaet hart thoe dragen, daer wt dat soude mogen spruiten eenige viautschap, haet ofte groot quaet; maer ter contrarie sullen malcanderen jn alle vrientschap bejegenen ende die reste sal men Godt Almachtich beuelen.

Item so belouen alle die hoofden ende overicheden van die steảen vant lant Banda, als oock mede die hoofden van die eijlanden, als Pulo Waị, Pulo Rum ende Rossamgijn, datse den Hollandschen oppercoopman Heijndrick van Bergel met alle sijn volck onder sijn gebiet staende, sullen onder hare bewaringe ende bescherminge houden ende jn alle gerechticheit voorstaen, niet thoe laten dat hem ofte ijmant van de sijne, tware van Bandanesen ofte eenige wtlansche vianden, eenich quaet ofte letsel souden mogen aengedaen werden, maer sullen voor haer sorge dragen gelijck se doen souden voor haer eijgen vrouwen ende kinderen, opdat haer geen overlast en geschiede.

Item so belooft wederom den oppercoopman Heijndrick van

1 Uit de papieren van Van Buchel, waaronder aanteekeningen van Van der Haghen in HS. Gedrukt in de Bijdragen en Mededeelingen van het Historisch Genootschap, VI (1883), bldz. 307 v. v.

2 Vgl. Van der Chijs, t. a. p., bldz. 25.

s Vgl. Van der Chijs, t. a. p., bldz. 23. 
Bergel met sijne Hollanders ende andere natien jn sijnen dienste weesende, bij aldien datter eenige vreembde vianden quamen om Banda te beoorlogen ofte beschadigen, dat hij met syne macht na sijn vermogen tlant sal assisteren, bewaren ende hellepen beschermen met die middelen, die haer Godt verleent heeft, maer jngevalle datter sake waer, datter wederom eenige jnlantschen twist ofte oorloge jnt lant Banda opstont, so en sal den Oppercoopman met sijn volck hem met sulcx niet bemoijen maer sullen stille sitten, doch sullen wel vermogen haer beste te doen om wederom die steden te vereenigen ende die vreede te hellepen maken.

Item oft tsake ware datter van den Oppercoopmans volck onder hem staende ijmant quame te ontlopen, so en sullen die van Banda niet uermogen alsulcke personen op te houden, versteken ofte fauoriseren, ende veel min soeken te trecken tot haer Mahumets gelooff ende haer Christen gelooff daerdoor versaken; maer ter contrarie so sullen se gehouden wesen, alsulcke weederomme te geven ende te leueren jn handen van haren oversten die met haer sal omgaen ende tracteren na behoren. Ende over sulcx so sullen se den oversten laten gewerden met die administratie van de justitie, want sulcx dient gedaen tot onderhouding van de vrede, goede oorden ${ }^{1}$ ende politie.

Item alle die overicheden ende jnwoonders van d eijlanden van Banda sullen die Hollanders jn hare huisen tot Nera, Salama ende Ortatan met goede ruste ende vreede laten wonen, ende oock mede naderhant, als den Admirael vertrocken sal weesen, haer niet moijelicken te vallen om van haer eenige coopmanschappen ofte goederen voor minderen prijs te copen als die prisen daer niet op gestelt sijn, ofte haer eenige andere quellagie aen te doen, $t$ waer om haer goet aff te borgen ofte geld affleenen, waerdoor dat grote twisten, viantschap ende grote oneenicheit soude mogen wtrijsen, maer ter contrarie sullen de Bandanesen die Hollanders gerustelicken ende vreedelicken laten copen ende vercopen, gelijck dat behoort ende die rechte maniere is van handelen.

Item sullen die overicheden ende alle inwoonders van d eijlanden van Banda met hare bontgenoten gehouden weesen, aen die Hollanders alle hare noten ende folie te vercopen tot alsulleken prijs alse met den anderen sullen acorderen ende overeencomen, die welcke Hollanders sullen maken dat die van Banda van victalie

1 Ordre? 
ende alderhande coopmanschappen van sulcx genoech sullen versien werden, als oock meede van gout ende silver, maer jngevalle datter sake waer, dat die Bandanesen eenige coopmanschappeu van doen hadden, die welcke bij die Hollanders niet te vinden waren, jn sulleken gevalle sullen se mogen handelen met die andere natien die sulcx hebben.

Item alle dese voorschreven, pointe ende arthikele belouen wij, hoofden ende ouericheden van $d$ eijlanden van Banda ter eenre sijden ende den Oppercoopman met sijne Hollanders ter ander sijde, dat wij dese arthikelen ende pointen ten vollen sullen onderhouden ende doen onderhouden, also dat wie die gene ware, tsij Bandanesen ofte Hollanders, die deze arthikelen contrarieerde ofte quamen te breken, so sullen die ouertreders als perturbateurs ende verstoorders vant tgemeene weluaren, die schepen van Hollant ouercomende, aen die ouericheit van die werden overgelevert om gestraft te werden na verdienste. Dese voorschreven poincten sijn bij parthien besworen ende beedicht na te comen, ende sijn weederom voor gelezen jn de grote vergaderinge tot Comber, daerse altemael een goet behagen jn hadden, weesende daermede wel te vreeden. Actum tot Comber, desen $13^{\mathrm{e}}$ Julio $\mathrm{A}^{\circ} 1605$.

\section{DJOHOR.}

17 Mei 1606. ${ }^{1}$.

In Mei 1605 was Cornelis Matelieff de jonge met een flinke Compagnie's vloot uit Nederland vertrokken. Onderweg ontmoette hij op Mauritius Steven van der Haghen, die op zijn terugreis was naar patria. Hunne besprekingen leidden er toe, dat Matelieff koers zette bepaaldelijk naar het Portugeesche Malaka, om het bevriende Djohor, dat, zooals Van der Haghen - ten onrechte - meende, door de Portugeezen werd belegerd, te ontzetten. Een insluiting van Malaka door Matelieff en de Djohorieten (Mei-Augustus 1606) had niet het gewenschte gevolg; de bedreigde stad werd door een Portugeesche vloot ontzet. Inmiddels was den 17 Mei een contract gesloten met den vorst van Djohor, met welk rijk Jacob van Heemskerck reeds in Februari 1603 vriendschappelijke betrekkingen had aangeknoopt. (Vgl. Tiele, Europeërs, VI, bldz. 56 en VII, bldz. 113-117; Netscher, Djohor, bldz. 9-15).

Accordt gemaeckt tusschen den admirael Cornelis Mateliff de Jonge, uyt den name ende van wegens d'Ed ${ }^{\text {le }}$ Mogende Heeren Staten Generael der Vereenighde Nederlanden ter eenre ende den doorlugh-

1 Uit het Contractboek. 
tigen en maghtigen koninck van Johor ter andere zijde, desen $17^{\mathrm{e}}$ Mey 1606, in 't schip Oranje, leggende op de reede van Malacca.

In den eersten beloofft den zelven admiraell uijt den name als boven ten versoecke van den zelven koningh, hem te helpen jnnemen en overweldigen de stadt van Malacca uyt handen van de Portugesen, haer beijder vijanden, waertoe elck sijn uijterste vermogen zal emploijeren om deselve daeruijt te drijven. Welck exploijt met Godes hulpe volbraght sijnde, zall dezelve bemeurde stadt, gelijck se tegenwoordig is, bimnen haere wallen ende meuren blijven jn vrijen eijgendomme, eeuwelijck, sonder eenige belastingh offte overheijt te erkennen, aeu de Heeren Staten voorschreven, het welcke den voorschreven coninck mits desen tot een loon van den krijgh is gevende ende zall voorschreven het geheele landt onder subjectie van Zijn Maijesteijt blijven, well verstaende dat de Heeren Staten voorschreven offte haeren capiteijnen geoorloofft sall wesen, alsoo se de stadt meenen te verstrecken, 1 soo veell landts tot deselve vortificatie te nemen als haer geraeden zall duncken. ${ }^{2}$.

2.

Zullen de voorschreven Heeren Staten ook vermogen in alle des Coninghs landen hout te haelen ende te houwen tot bouwingh van de schepen ende nooddrufftigheijt van de stadt.

3.

Zullen alle vasallen van de Heren Staten voorschreven haere schepen ende goederen, t'zij van wadt plaetse datse comen, ook gehuerde schepen, joncken ende prauwen in de voorschreveu stadt mogen lossen, zonder dat de Koningh daer ijet op te zeggen zal hebben noghte eenigen toll daeraff genieten, in nogh uijt.

4.

Zall de Koningh ook niet toelaeten datter eenige Hollanders, Europische volckeren offte haere naekomelingen in eenige van zijne landen sullen mogen handelen, offte sullen moeten bescheijden hebben van den gouverneur van Malacca ende t'selve niet hebben(de), zullen als vijanden gehouden, ende vervolght worden.

1 Schrijffout voor versterken.

2 Malaka is niet bemachtigd, dus dit artikel en sommige andere bepalingen van dit contract hebben geene gevolgen gehad. 
5 .

Hiertegen zall zijne Maijesteijt de voorstadt, Campo Clin 1, die nu affgebrandt is, peupleren ende regeren, zonder datter de Heeren Staten ijet op te zeggen sullen hebben ende, soo het mogelijck is, zijne residentie aldaer nemen ende dezelve daer versterken, waertoe hem de Heeren Staten voorschreven met raedt behulpelijck sullen wesen.

6.

Zall Zijne Maijesteijt nae de veroveringh van de stadt genieten alle het geschut, datter in gevonden wordt, waeraff hij vermogen zall d'eene helfft datelijck wegh te nemen ende de andere helfft sall gehouden wesen in de stadt tot defensie van de selve te laten, soo langh tot datse bij de Heeren Staten geprovideert wordt.

7.

Tgeene in de stadt zall gevonden worden van coopmanschap, gelt, waren en andersints zall komen d'eene helfft tot profijt van de fasaleu van de voorschreven Heeren Staten dezer vloote ende d'andere helfft aen Zijne Maijesteijt voorschreven.

\section{8.}

Alle coopmanschappen, niet toebehoorende de vasalen van de Heeren Staten voorschreven, sullen gehouden wesen de ${ }^{2}$ lossen onder des Koninghs gebiedt, jn de voorstadt, alwaert de vasalen van de Heeren Staten vrij sall staen deselve te komen koopen neffens andere ende dezelve in de stadt te brenghen.

9.

Zullen voorschreven malkanderen bijstaen ende helpen met alle maght ende nae uijtterste vermogen, om de Portugesen en Spangiaerden, haer beijder vijanden, alle mogelijke affbreuck te doen, ende zoo ymandt van de partijen oorlogh aen nam tegen ymandt anders als Portugesen en Spangiaerden, zall d'andere partijen niet gehouden wesen denselven te assisteren dan alleenlijck in defensie.

\section{0.}

Zall ook geen van beyde de partijen pays mogen maken met de koningh van Spanjen zonder beijder consent.

1 Kampong Kling. De naam dezer voorstad welke "weynich buyten de stadt gelegen" was en in den tijd der Portugeezen versterkt was (DaghRegister 1640-1641, bldz. 208, 465) zal te danken zijn aan de Orang Kling, de Klingaleezen, van de kust van Koromandel (welks Noordelijk gedeelte vroeger Kalinga werd genoemd: Hobson-Jobson, p. 372; Hunter, Gazetteer, V, p. 163), en andere vreemdelingen uit Voor-Indië.

2 Moet zijn: "te". 


\section{1.}

Zoo wie eenigh schandaell jn religions zaken geefft, zall aengeklaeght en gestrafft worden bij zijn overheijdt daer hij onder sorteert, soo wel van d'eene als van de ander zijde.

12.

Soo eenige persoonen van d'een off d'ander parthije yet op den anderen hadde te seggen van schuldt off andersints zall de verweerder voor zijne overheijt geroepen worden

13.

Zoo ymandt van de Hollanders overliep bij den koningh van Johor om eenige quade delicten offte andersints offfe van des Konings volck bij de Nederlanders, zullen de partijen gehouden zijn den wegheloopen aen zijne overheijdt in handen te leveren.

Int maeken van dese artykelen begeerde Ragia Sabrangh, ${ }^{1}$ dewijll alles rondsom de stadt meest was affgebrandt, dat, als dat de staet ${ }^{2}$ soude verovert zijn, men den Admirael plaets soude ${ }^{3}$ ende hnijsingh om te logeren binnen deselve stadt, latende het cassteell voor den Koningh, waer op den Admiraell antwoorde, alles te willen doen dat Sijne Mayesteijt begeerde, den zelven noghtans biddende niet te begeeren willen zulcken dingen, die haer ende den onsen moghten gedijen tot schade, wandt den gouverneur, die den Admiraell stellen soude, nogh 4 int cassteell woonen, ende hem t'elckens hem daer uijt te doen gaen als Zijne Mayesteijt quame, zoude veell te swaer voor hem te vallen. Eijndelijck werter besloten dat den Admiraell voor des Koninghs persoon soude versorgen sulcke huysingh, daer hij in logeren moghte soo dickwijls als t hem belieffde, vergeselschapt met 15 off 17 persoone van zijn gevolgh totter tijds datter bequame wooningh in Campo Cleijn soude wesen gemaeckt, waarmede den Koningh te vreden was. Ende alhoewell den Admiraell het geschut ende den buijt te voren aen het volck

1 Radja Sabĕrang: de koning van de overzijde. Hij, ook genoemd radja Bongsoe (de jongste), was een broeder van den vorst (jang dipertoewan) van Djohor en deelde met hem het bestuur over het rijk. Hij had zich aan de overzijde der rivier gevestigd, „tegenover de stadt Batoe Sawar", vanwaar zijn naam, en was een man van grooten invloed. (Vgl. Netscher, Djohor, bldz. 10 , v.)

2 Moet zijn: "stadt".

s Hier is uitgevallen: "geven" of iets dergelijks.

4 Moest? Vgl. Netscher, Djohor, bldz. II. 
hadde beloofft, jndien zij de stadt stormenderhandt quamen te veroveren offte anders het t'geene zij tot randtsoen zouden bedingen gelijck hiervooren geseijt is, heefft hij noghans all t' geschut ende de helfft van den buijt aen den Koningh ${ }^{1}$ mede liedt volgen de tollen van de vreemde natiën, was geschiet omdat hij sijne rekeningh maeckt, dat alle die in de stadt quamen woonen zouden vrij sijn, waerdoor dan veele luyden zouden aengelockt werden, de stadt te komen bevolcken, ende men zoude mettertijt genoegh volck uyt het vaderlandt brengen, datt d'onse maghtigh genoegh soude sijn hun te defenseren, sonder hulpe van Johor ende ook alle vaerten met haer eijgen volck te bevaren. ${ }^{2}$.

Welck accoordt naderhandt bij den Koningh, jn de vloote komende, geapprobeerdt is, zulcx dat hij nevens raija Sabrangh ter eenre ende den Admiraell ter andere zijde t zelve besworen en onderteekent hebben.

De forma van den eedt, daeronder aen gevoeght, luijdt als volght: Wij, jan de patuan ${ }^{3}$ en raijja Sabrangh, koningh ${ }^{4}$ tot Johor, belooven mits desen te onderhouden dit bovenschreven accoordt in alle sijne puncten en artijkulen zonder daerin eeniger manieren tegen te doen. Soo waerlijck moedt ons Godt helpen.

Ick Cornelis Matelief de Jonge, uijt den naem van de Ed Mogende Heeren Staten Generaell der Vereenighde Nederlanden, beloove mitsdesen alle de boven geschreven artijkelen in alle haere deelen naer te komen sonder daerin eeniger manieren tegen te doen. Zoo waarlijck moet mij Godt almachtigh helpen.

\section{KUST VAN KOROMANDEL.}

Angustus 1606. 5

Een der schepen van de vloot van Van der Haghen, de Delft, verliet in December 1604 de vloot met bestemming naar Atjeh en daarna naar de Kust van Koromandel. Aan boord was de opperkoopman Paulus van Soldt. Men liet toen eenige Nederlanders te Masulipatam (ten Noorden der mondingen van de Kistna), aan die kust achter, om handel te

1 Hier is iets uitgevallen, misschien „geaccordeerd en ingewilligd. Dat den Admiraal den Koning mede", enz. (Netscher, Djohor, bldz. III).

2 Dit laatste behoort natuurlijk niet tot het contract.

3 Jang dipertoewan.

4 Netscher, bldz. 14, heeft "Koningen".

${ }^{5}$ Uit het Contractboek. 
drijven. De Delft kwam den 21 Augustus 1605 te Bantam en vertrok den 5 December 1605 opnieuw naar de Kust, waar verschillende plaatsen werden bezocht, vóór men weder te Masulipatam kwam. Van dáár begaf zich Van Soldt, die ook deze reis medemaakte, naar den sultan van Golconda, toen een machtig Mohammedaansch rijk ${ }^{1}$ in Deccan, waartoe ook Masulipatam behoorde. Hij verkreeg verschillende voorrechten van dien potentaat, welke medegedeeld worden in onderstaand extract van den ferman (Vgl. De Jonge, Opkomst, III, bldz. 39-41).

Privilegien offte firman ${ }^{2}$ van den koningh van Golconda aen de Comp $^{e}$ verleend jn Augusto 1606, ten eijnde ${ }^{3}$ als den ondercoopman Paulus van Solt derwaerts gereijst is.

Dat de Compe van. toll van jnkomen sall geven 4 ten 100 ende van uijtgaen 4 ten 100 ende dat in alle plaetsen van het coninckrijck, zoo well jn de plaetsen daer zij nu sijn als jn de plaetsen daer zij nogh zouden mogen komen; zonder meer.

Dat alle wevers, schilders, smits en alderhande ambaghtluijden, voor de Comp ${ }^{e}$ werckende offte gelt in handen hebbende, van wegen den Koningh offte ijmandt anders niet en zullen gemoeijt worden, tot dat het werck voldaen zij.

Dat alle makelaers vrij in $\mathrm{Comp}^{8}$ logie ${ }^{4}$ sulleu mogen koomen ende dat d'onse alsulcken makelaar mogen verkiezen als haar goedtdunckt, zonder verbonden te staen aen den geenen die haer den Gouvern $^{\mathrm{r}}$ hadde willen geven.

Den Koningh doet ook niet ${ }^{5}$ het reght genaemt choppadellalla ${ }^{6}$, dat is het seegel, 't welcken op het linnen set, bedragende 12 ten 100 , waervan hij de Compe bevrijdt boven zijne onderzaten ende alle andere vreemde natien, die het selven moeten betalen.

1 Een plaatsje van dien naám ligt nog ten Westen van Haidarabad: het is de oude hoofdstad van het Rijk. In den strijd met het machtige Vijayanagar of Vijaya-nagaram (Vizianagram of Bisnagar), bemachtigde Golkonda deelen van dit Hindoe-rïk van Zuid-Westelijk Deccan, nadat dit ten gevolge van den nederlaag bij Talikot of Tellicotta (1565), het door een verbond van Mohammedaansche vorsten toegebracht, doodelijk verzwakt was. Zie o. a. J. D. B. Gribble, A history of the Deccan, I, (London, Luzac, 1896) p. 171, 186-196 en de kaarten; W. W. Hunter, The Imperial Gazetteer of India, III, Londen, Trübner, 1881) p. 423, VIII, p. 511, IX, p. 242 etc.

${ }^{2}$ Ferman $=$ een order, open brief, schriftelijk bevel.

3 Moet zijn: ten tijde.

4 Van Mazulipatam.

5 Te niet?

${ }^{6}$ Is mij niet duidelijk. Het eerste gedeelte zal wel zijn: chop of chhāp = zegel (tjap). (Vgl. Hobson-Jobson, p. 159). 


\section{DJOHOR.}

\section{September 1606. ${ }^{1}$}

$\mathrm{Na}$ het ontzet van Malaka door de Portugeezen trad Matelieff met den jang dipertoewan van Djohor opnieuw in besprekingen, welke leidden tot een nieuwe overeenkomst. (Vgl. Tiele, Europeërs, VII, bldz. 117).

Tweede accoordt gemaeckt tusschen den heer admiraell Cornelis Maetelieff de jonge uyt den name en van wegen $d^{\prime} E d^{\text {en }}$ Mogende $\mathrm{H}^{\text {ren }}$ Staten generaell der Vereenighde Nederlanden ten eenre ende den doorlughtigen en manhaften Koningh van Johor ter andere zyde desen $23^{\mathrm{e}}$ 7 ber jnt jaer onses Heeren Jesu Christij 1606 jn de stadt Batosauwer. 2

In den eersten worden geconfirmeert alle artijkulen begrepen jn accoordt tusschen partijen gemaeckt in dato den $17^{\mathrm{e}}$ Mey deses jaers int schip Orangie op de reede voor Malacca. ${ }^{3}$

Dogh dewijll het Godt almaghtigh niet en heefft beliefft, dat de stadt en de fortresse van Malacca tot nogh toe hebben kunnen veroveren, waerdoor eenige artijkulen van wederzijde niet en konnen onderhouden worden, als namentlijck het besitt van de stadt voor de Heeren Staten ende van de voorstadt mitschaders het geheele landt voor den koningh van Johor, willen sulcx tot naerder geleegentheijt uijtstellen, dat Godt de Heere gracie zall believen te geven tot veroveringh derzelver, door neerstigheijt van de Heeren Staten ende den koningh van Johor.

Ende alsoo het noodigh is, dat de Heeren Staten voor hare ondersaten tot bevorderingh van de negociatie van de selve in Oostjndien, een versekerde plaets hebben om haere goederen, koopmanschappen, ammonitien, toerustingen ende andersints te versamelen ende bevaeren ${ }^{4}$, ook des noodts zijnde ambaghtluijden ende huysgezinnen te mogen brengen uijt haer landt, sall Syne Majesteyt de coninck van Johor aen de Heeren Staten offte haeren cap $^{n}$ geven sulcken plaets, als zij sullen begeeren, t'zy hier aen het vaste landt offte eenige eijlanden onder 't gebiedt van Sijne Mayesteijt wesende, soo groot offte cleijn als d'Heeren Staten offte haeren cap ${ }^{t}$ sall goedtduncken, om aldaer haere huysingen ende wooninge te mogen bouwen ende die besitten als Malacca.

1 Uit het Contractboek.

${ }^{2}$ Batoe Sawar. Deze plaats ligt aan de rivier van Djohor, maar meer landwaarts in dan Djohor, dat aan de kust gelegen is.

${ }^{3} \mathrm{~N}^{\circ}$ XVIII dezer contracten.

4 Bewaren? 
Des soo sullen wederom de Heeren Staten ende haere ondersaten gehouden wesen te volbrengen de artykulen int accoordt, voor Malacca gemaeckt, begrepen.

Aldus gedaen jn Batasauwer ten dage ende jaren als boven.

\section{ATJFH.}

\section{Januari 1607. 1}

Matelieff bleef tot het begin van 1607 kruisen in de buurt van het Maleische schiereiland en vertrok van dáár naar Bantam.' Zijn vice-admiraal, Olivier de Vivere, werd door hem naar Atjeh gezonden, tot welk rijk de verhouding in de laatste jaren van vriendelijken aard was geweest, terwijl integendeel de Sultan in den allerlaatsten tijd. op vijandigen voet stond met de Portugeezen. De Vivere werd zeer goed ontvangen en sloot met den Sultan een contract. (Vgl. Tiele, Europeërs, VII, bldz. 116, 119-120).

Accoordt gemaekt tusschen den vice admiraell Olivier van Vivere uijt den name ende van wegen de $\mathrm{Ed}^{\mathrm{e}}$ Mogende Heeren Staten Generaell der vereenighde Nederlanden ter eenre ende den doorlughtige Coninck van Atchin ter andere zijde desen $17^{\mathrm{e}}$ Januarij vant jaer Onses Heeren Jesu Christij 1607 jn de stadt Atchin.

1.

In den eersten, alsoo nodigh is, dat de Heeren Staten voor haere capiteijnen tot bevorderingh van de negotie van deselve jn Oostjndien een versekerde ende vaste plaetse hebben, ${ }^{2}$ om haere goederen, koopmanschappen ende ammunitie van oorlooge, als geschut, roers, harnassen, spiessen, kruijdt, loodt, lonten, kabels, alderhande touwerck, balcken, plancken, arpuijs, teer, peck en andersints te versamelen, ende bewaeren, ook des noodts zijnde ambaghtluijden ende huijsgezinnen te mogen brengen uijt haer landt, zal Zijn Maijesteijt aen de Heeren Staten, offte haere capiteijnen geven alsulcke plaetse als zij zullen begeeren, t'zij hier offte in eenige eijlanden onder het gebiedt van Zijn Maijesteijt wesende, soo groot oflte cleijn als de Heeren Staten offte zijne capiteijnen sall goedtduncken.

2 .

Alle coopmanschappen, komende met vreemde natien in dese

1 Uit het Contractboek.

2 Vgl. het contract met Djohor, $\mathrm{n}^{\circ} \mathrm{XX}$. 
plaetse onder het gebiedt van Zijne Maijt, als ook deselve binnen de landen van Zijne Maijesteijt vallende, zullen de vasalen van de Heeren Staten -vrij staen deselve te mogen koopen neffens andere zonder dat eenige vreemdelingen hetzelve sullen mogen verbieden onder 't decksell van Sijne Maijesteijts last, waermede Sijne Maijt ende de onse bedrogen worden ende het vervreemdingh onder de natie maekt.

\section{3.}

Sullen de vasalen van de Heeren Staten voorschreven haere schepen ende goederen, t zij van wadt plaetsen dat zij komen, ook wederom versonden worden, mogen disponeeren, sonder dat Sijne Maijesteijt daerijets op sall te seggen hebben nogh eenige toll daeraff te nemen, nogh uijt nogh in.

4.

Sall ook sijne Maijt niet toelaeten, datter eenige Hollanders, Europische volckeren offte naekomelingen in eenige van zijne landen sullen mogen handelen, offte zullen bescheijdt van onse coningh ${ }^{1}$ moeten brengen ende het zelve niet hebbende, sullen als vijanden gehouden en vervolght worden.

5.

Sullen de voorschreven Heeren Staten ook vermogen in alle des Coninghs landen hout te haelen en te houwen tot bouwingh van de schepen ende noodrufftigheijt van haere woonplaets.

6.

Sall ook geene van d'beijde partijen vermogen paijs te maeken met de koninghk van Spangien zonder breeder ${ }^{2}$ consent.

7.

Soo wie eenige schandale in eenige religions saeken geefft, die sall aengeklaeght ende gestrafft worden bij sijne overheijt, daer hij onder sorteert, zoo well van d'eene als van de andere zijde.

\section{8.}

Soo eenige persoonen van d'een en d'andere partijen yets op anderen hadden te seggen van schuldt en wederschuldt, t' zij door leenen offte coopmanschappen, hoe het zoude geschieden, zall de Koningh gehouden wesen te eersten versoek van den aenklager reght te doen.

1 Vgl. hiervóór noot 2 op bldz. 6.

2 Beider? $7^{\circ}$ Volgr. III. 
9.

Soo daer ijmandt van d'onse ${ }^{1}$ om eenigh quadt rumoer bij zijne Maijt hulpe versoght, 't sij met looghenen van sijn geloove offte andersints, om sijn quadt leven te bedecken, zall Zijne Mayesteijt hem aenhouden, maar geven hem ter bewaringh van de onse, om ter gelegener tijt zulcken straffe daerover te doen datter een ander exempell aen zall nemen.

\section{0.}

Hier en tegen sullen de Heeren Staten sijne Mayesteijt helpen met alle maght naer uijtterste vermogen, om de Portugesen en Spanjiaerden, haerer beijder vijanden, alle mogelijcke affbreuck te doen; ende soo ijmandt van de partijen oorlogh aennam tegen ymandt anders als de Portugesen ende Spangiaerden zall de andere partije niet gehoudeu wesen deselve te assisteren, dan alleenlijck in defensie.

\section{1.}

Sijne May ${ }^{t}$ eenige wapenen uijt onse landen van doen hebbende, hoe die souden mogen wesen, zulleu deselve brengen, mits dat Sijne Maijt ons daer geldt offte waeren voor zall geven, voor soo veel deselve in ons landt kosten.

\section{MOLUKKEN.}

\section{Mei 1607. 2}

Matelieff was den 31 Januari 1607 te Bamtam gekomen en vond daar gezanten van Ternate, om onze hulp in te roepen. In Mei 1605 hadden de Nederlanders de Portugeezen van Ternate verdreven zonder zelf daar een versterking te bezetten. Je Spanjaarden badden zich dan ook in April 1606 op het eiland kunnen vestigen, na het oude Portugeesche fort bij Gamoe Lamoe op de Ternatanen te hebben veroverd: de Molukken werden toen door Spanje als een Spaansche bezitting beschouwd. Hulp werd thans van de Nederlanders gerraagd. Matelieff kwam in Mei 1607 met eenige schepen in die streken en ging op het denkbeeld van den sultan van Ternate in, om eveneens op dit eiland een vast punt in te .nemen. Hij koos Malajoe, aan de Noordoostzijde van het eiland. Een contract werd verder met den Sultan"gesloten. (Vgl. Tiele, Europeërs, VI, bldz. 95-97; VII, bldz. 106-111, 125-126).

1 De Nederlanders. Men kan uit deze en dergelijke uitdrukkingen zien, dat dikwijls de contracten door de onzen werden geconcipieerd.

2 Uit het Contractboek. 
Accoordt gemaeckt tusschen admirael Cornelis Matelieff de jonge van wegen en uijt de name van de Heeren Staten Gener der Vereenighde Nederlansche provintien ter eenre ende den koningh van Ternaten ende sijne Rade ter andere zijde, desen $26^{\mathrm{e}}$ Meij ${ }^{1} \mathrm{~A}^{\circ} 1607$, voor Maleije.

1.

Eerstelijck sall den Admiraell, die ons hier weder op Ternaten gebraght heefft, met all sijn vloote hier blijven tot der tijtd het bolwerck, aent water gelegen van dese plaetse van Maleyo, die hij begonnen heefft sterck te maeken, volkomen in defentie is.

2 .

Op sijn vertreck sall hier laeten vier schepen, Enckhuijsen, de Zon, Delfft en het jaght ${ }^{2}$, van welcke schepen altijd aenlandt sullen wesen 30 à 40 mannen in wapenen tot bewaringh van 't bollwerck.

3.

Sall het selve bolwerck behoorlijck versien met geschut; zall ook hier eenigh geschut laeten tot provisie van de andere bollwercken die nogh in de plaets Maleije sullen gemaeckt worden.

4.

Sall bestellen, dat met den eersten advijs nae Ambon ende Bantam gae, op dat toekomende Februarij hier nogh 2 schepen mogen komen, om alsoo met behoorlijcke maght gereet te wesen tegen het secours, dat uijt de Manilhas ${ }^{3}$ zoude mogen komen, waertoe de Ternatanen prauwen sullen besorgen.

5.

De Admiraell sall gehouden wesen, als hij in Hollandt komt, de zaken van Ternaten ten hooghsten te beveelen aan de Heeren Staten, opdat ze volck mogen senden om de Casstelanen uijt Tarnaten te jagen, waertoe de Ternatanen neffens dese volle maght zijn gevende, om in haren naem haere saeken te vervorderen.

6.

Hiertegen sullen de Ternatanen d'Ed. Moog: Heeren Staten aennemen en kennen voor haeren beschermheer, waervan zij den eedt sullen doen, als d'E. Heeren Staten sall gelieven.

1 Valentijn, I, b, bldz. 224, stelt het op 26 Juni. Matelieff vertrok echter reeds 12 Juni naar China.

${ }^{2}$ Het Duifke.

3 Nl. voor de Spanjaarden. 
7.

De onkossten, die gedaen sijn ende nogh gedaen souden mogen werden jn de oorlooge, zullen de Ternatanen betaelen, zoo haest als zij het vermogen hebben, $t$ welck sall staen tot oordeell van de Heeren Staten, wanneer ende hoeveel.

8.

De guarnisoenen, die hier gelaeten worden, zullen uijt de tollen van de Ternatanen als van onderdanige landen van de kroon van Ternaten betaelt worden.

9.

Sullen ook gehouden wesen, alle Ternatanen, die verstroijt zijn in d'omleggende landen, met den eersten op Ternate te doen komen, ook alle ondersaten van de kroone van Ternaten als Xula, Bouro, Combello ${ }^{1}$, Loehoe, Meau ${ }^{2}$ en Manado, die op het eijland Celebes woonen, als die van Gilolo, More ${ }^{3}$, Serranganij ${ }^{4}$ en Mindanaww ${ }^{5}$, zoo veell als doenelijck is, op dat door de menighte der Ternatanen het verdrijven van de Castelanen te lighter zall vallen ende het volck gereedt sal wesen, als daer secours van Hollanders kompt.

10.

Sullen geene nagelen moogen verkoopen, 't zy aen wadt natie offte volck hetselve soude mogen wesen dan alleen aen den factoor die van wegen de Heeren Staten in Ternate sall woonen ende dat tot sulcken prijs als de Heeren Staten sullen ordineeren ende met den Koningh accordeeren.

\section{1.}

Niemandt van beijde partyen zall den anderen vermogen te verongelycken, maer soo ijmandt van de Hollanders de Ternatanen verongelyckt, zall hij bij sijne overheijdt aengeklaegt en gestrafft worden; desgelijcks ook van wegen de Ternatanen.

12.

In saeken van religie zall niemandt den anderen mogen bespotten

1 Kambelo op Klein-Ceram.

2 Majoe.

$s$ Moro (Noordwesthoek van Halmaheira) of Mohore (een der Sangi-eilanden volgens Valentijn's kaart der Molukken)?

4 Sarangani-eilanden, ten Zuiden van Mindanao.

5 In een concept van dit contract, eveneens in het contractenboek opgenomen, worden nog genoemd: „Manipa, Mora, Lolodo, Gamcannorre, Gilolo, Sebou", maar er is daar geen sprake van „ondersaten", maar van „plaetsen die den Koningh toegedaen sijn." Mora = More ?; Lolodo, Gamoekanora, Saboewe of Saboegoe, allen op de Westkust van Halmaheira. 
offte verhinderen, maer elck leven als hij voor Godt will andtwoorden.

13.

Zoo der ijmandt van de Hollanders overliep bij de Ternatanen, zall van de Ternatanen weder geleverd worden, desgelycx zoo ijmandt van de Ternatanen bij de Hollanders quame, zall van haer mede weder gelevert worden.

14.

Zonder consent van beyde partijen zall niemandt met de Spanjaerden noghte Tijdoresen 1 vrede moogen maeken.

Aldus gedaen ten dage ende jaere als boven. Was geteekent C. Matelieff de jonge.

\section{KUST VAN MALABAAR.}

13 October 1608. 2

Aan de bepalingen van het verdrag met Kalikoet van 11 November 1604 was nog geen gevolg gegeven, toen in 1607 Paulus van Caerden daar verscheen, en het verdrag bevestigde. In October 1608 kwam daar Pieter Willemszoon Verhoeff en sloot het onderstaand verdrag. (Vgl. De Jonge, Opkomst, III, bldz. 64-65, 75-76, 258, 246).

Accoord tusschen den admirael Pieter Willemse Verhoeff ende grooten Keijzer van Calicut.

Allen den geenen, die desen sullen sien offte hooren lezen, saluijt, doen te weten: alsoo op den $11^{\mathrm{n}}$ November $\mathrm{A}^{0} 1604$ tusschen den doorlughtigen hooghst gebooren en grootmaghtigen sammorijn, keijzer van Malabaer, koningh van Calicut, ter eenre ende den gestrengen heer Steven van der Hagen, admiraell van 13 groote Nederlandsche schepen, van wegen de hooghgeboorne Mogende $\mathrm{H}^{\text {ren }}$ Staten Generaell der Vereenighde Nederlansche provintien, Zijne Princelijcke Ex ${ }^{\text {tie }}$ van Nassou ende de $\mathrm{H}^{\text {ren }}$ Bewinthebberen der Oostjndische Comp ${ }^{\text {e }}$ ter andere zijde, zeker contract ${ }^{3}$ opgereght ende gemaect was, streckende en tenderende tot augimentatie ende reservatie van onderlinge vrundschap en alliantie tusschen des gedaghten mogenden keijzers onderdanen ende onse

1 Toen bondgenooten der Spanjaarden.

2 Uit het Contractboek.

s No. XIII. 
voorschreven Nederlandsche natie, ende ruinerende de alliantie ${ }^{1}$ van de Portugesen neffens hare geassocieerde ende dat ons deze saeke generalijck van d' Ed ${ }^{l e}$ geboorne Mogende Heeren Staten Genr ${ }^{1}$, Zijn Princelijcke Ex ${ }^{\text {tie}}$, de Heeren Bewinthebberen voorschreven gerecommandeerdt was, soo hebben wij, Pieter Willemszoon Verhoeff, admr ${ }^{1}$ gener $^{1}$ van 13 groote Nederlansche schepen wegen de Welgeboorne Moogende Heeren Staten Gener', Zijne Princelijcke Ex ${ }^{\text {tie }}$ ende d' $\mathrm{H}^{\text {re }}$ Bewinthebberen voorschreven, met advijs van onsen voorzeijde raedt ende door last ende requisitie van Zijne Keijzerlijcke Maijt 2 alle faveur, hulpe en assistentie met schepen en volck te doen om Zijne Maij ${ }^{\text {ts }}$ en onse vijanden te ruineren en te destrueeren, als ons $\operatorname{dogh}^{3}$ mogelijck sall wesen ende tot dien fine twee schepen van Bantam neffens well gequalificeerde coopluijden ende cargasoen van onse natie naer Calicut affsenden, om handelinge en commercie van coopmanschappen aldaer te beginnen ende te drijven ende dat middelertijt de schepen tot zijne Keijzerl ${ }^{\mathrm{n}}$ Maij $^{\text {ts }}$ dienst jegens sijne en onse vijanden moge werden geemployeert, als de coopluijden voorschreven zullen doende zijn om haere coopmanschappen ende waren tot ladingh van de schepen noodigh bij een te versamelen. Dies heefft zijne Keijzerlijcke Maijt expresselijck beloofft, deselve coopluijden van onse natie met goede plaetsen ende wooningen, daer zij haere persoonen, goederen, coopmanschappen ende waeren mogen vertrouwen ende bequam mogen logeren, te provideren ende versien ende deselve nemen in sijn protectie ende beschermingh, zonder te lijden dat hun hinder offte leedt in eeniger wijse aengedaen wordt, maer ter contrarie hun te patrocineeren, zoo in 't stuck van hunne negotie als andersints; ende nopende de tollen ende andere lassten op commercie, deselve niet erger als sijne onderdanen te tracteren, maer veell eer soo veell in reden bestaet te priviligeren.

Aldus gedaen, gecontracteert ende geaccordeert tot Calicut den $13^{\text {e }} 8^{\text {ber }} A^{0} 1608$.

1 Het exemplaar bij De Jonge, Opkomst, III, bldz. 278, heeft: „ende tot ruine ende destructie van de Portugesen", enz.

2 De Jonge, t. a. p., bldz. 279, heeft nog: "t'voors. contract geadvoyeert ende geapprobeert, gelijek wij doen mits desen in alle zyne poincten ende articulen ende daer beneffens belooft zijne voors. Keyzerlijeke Ma"", enz.

s De Jonge, t. a. p., heeft: „als ons te doen", enz. 


\section{KUST VAN KOROMANIEL.}

\section{November 1608.1}

Op last van Verhoeff was de opperkoopman Jacob de Bitter van de Kust van Malabaar naar die van Koromandel gegaan met twee schepen. Hij bezocht de kantoren, welke de Oost-Indische Compagnie daar in 1605 en 1606 had gevestigd en richtte een nieuw kantoor op te Tegenapatnam ${ }^{2}$. Die stad was gelegen in het rijk van Gingi, welks hoofdplaats van denzelfden naam meer binnenwaarts lag ${ }^{3}$. Van dáár de sluiting van onderstaand contract. (Vgl. De Jonge, Opkomst, III, bldz. 76-78, 280-281).

\section{Copie van $\mathrm{t}$ caull ${ }^{4}$ van den coninck $^{5}$ van Gengier.}

Wij belooven aen Jacob de Bitter, cap ${ }^{\mathrm{n}}$ van weegen den admirael Pieter Willemssen Verhoeven, de Hollanders, die in Tegenampatnam zullen blijven, in onse bescherminge te nemen ende de statt op te laeten bouwen, ${ }^{6}$ oock de Portugijsen te ontseggen ende haer vijandt te blijven. ${ }^{7}$ Waertegen wij Hollanders beloven, alle coopmanschappen te brengen, ende met alle coopluijden te negotieeren, midts datt wij zullen betaelen 4 ten hondert van alle de goederen, die wij hier zullen brengen, wtgenomen de rijs die jn huijs gebruijct wordt ende het geldt, die en zullen niet betaelen. Voorts zullen wij betaelen 4 ten hondert van de goederen, die wij daer van daen zullen voeren, wtgenomen die eens betaelt hebben en zulleu niet weer betaelen. Welcke bovenschreven wij belooven ende sweeren, aen weder zijden overbreeckelijck te onderhouden. Amen.

Den $30^{\mathrm{n}}$ November Anno 1608. In de groote stadt Gengier.

1 Los in het Oud-Koloniaal archief. Het afschrift in het Contractboek heeft geen datum.

2 Ten Noorden van Porto Novo en ten Zuiden van Pondicherri. Vgl. ook Valentijns kaart van Koromandel en bldz. 9 van zijn deel over Koromandel.

3 Ten N.-W. van Pondicherri. Vgl. ook Valentijn, t. a. p., bldz. 10. Gingi (Djindji) was toen een onderhoorigheid van Vizianagar, waarvan de zetel in de jaren na den slag bij Talikot (1565) verplaatst was o. a. naar Chandragiri (ten Noordwesten van Madras), naar welke plaats het ook wel werd genoemd. (Gribble, Deccan, I, p. 195; Hunter, Gazetteer, III, p. 370).

${ }^{4}$ Cowle (kaul): een vrijgeleide, open brief, enz. (Hobson-Jobson, p. 209).

${ }^{5}$ Zijn titel zal die geweest zijn van Naïk (Nayak) = gouverneur. (Vgl. de bewijsplaatsen bij Hobson-Jobson, p. 470, onder c).

6 Vermoedelijk wordt hiermede bedoeld "het vervallen fort van de Portugysen". (De Jonge, Opkomst, III, bldz. 280).

7 Vgl. De Jonge, t. a. p., bldz. 281. 


\section{BANTAM.}

Feloruari 1609. 1

Toen het zoo goed als zeker mocht heeten, dat in Nederland een bestand zoude worden gesloten tusschen de Republiek en Spanje, zonden de Bewindhebbers der Oost-Indische Compagnie het bevel naar de Nederlandschê autoriteiten in het Oosten, om dit aan de Vorsten dáár mede te deelen en tevens om zooveel mogelijk „metten Indiaense Coninghen en Princen contracten van vruntschappe, aliantie en conditien van handel en trafique" te sluiten, omdat waarschijnlijk een der bepalingen van het bestand zoude zijn, "dat de eene partye nyet en sall mogen vaeren, daer de andere partye het gebiet off contract heeft". Ten gevolge van deze aanschrijving werd het volgende contract met Bantam gesloten door den opperkoopman Jaeques l'Hermite, die in 1607 tot president der, in 1603 te Bantam gestichte, loge der Oost-Indische Compagnie was opgetreden. (Vgl. De Jonge, Opkomst, III, bldz. 54, 91-93, 307-312, 395; Tiele, Europeërs, VII, bldz. 145-147).

Euwigh verbondt der Vereenighde Nederlansche provintien, Syne Princelijcke Ex ${ }^{\text {tie }}, d^{\prime} H^{\text {ren }}$ Bewinthebberen van de selffde landen, trafijcquerende op Oost Jndien, ter eenre ende den seer maghtigen koninck van Ban1am ende d'omliggende plaetsen ende de eylanden van Java ter andere zijde, den ... ${ }^{2}$ Februarij $\mathrm{A}^{0} 1609$ gemaekt.

Alsoo der apparentie is, dat tusschen den seer hooghmaghtigen Philipus de derde, koninck van Hispangien ende Portugal, neffens sijne gealieerde ende Ho: Mog: Heeren Staten Gener ${ }^{l}$ der Vereenighde Nederlandsche provintien ende sijne doorlughtige Princelijcke Ex ${ }^{\text {tie }}$ seeker contract, houdende jn de Oostjndies ende d'eijlanden van dien voor dien tijt van 9 jaeren ${ }^{3}$ gemaeckt zall worden.

Waerinne d'geallieerde vrunden + aen wedersijden gecomprehendeert mogen sijn, die de effecte van de voorschreven trebis(!) sullen hebben te genieten. Ende de voorschreven Mogende $\mathrm{H}^{\text {ren }}$ Staten Genr ${ }^{1}$, Zijne doorl. Princel. Ex ${ }^{\text {tie }}$ ende onderdanen in goede conservatie met den seer mogenden koninck van Bantham sijn staende, waervan een

1 Uit het Contractboek.

2 Niet ingevuld. Tiele's opmerking (t. a. p., bldz. 147, noot 2), dat het contract geene dagteekening heeft, is juist; maar de toevoeging van de maand, waarin 't contract is gesloten, komt eenigermate aan deze leemte tegemoet. Indien die toevoeging ten minste juist is, wat ik niet heb kunnen contrôleeren, maar ten opzichte waarvan ook geen bepaalde reden van twijfel bestaat in verband met wat De Jonge en Tiele hebben mèegedeeld.

$s \mathrm{Er}$ is een woord uitgevallen, b.v. trèves of iets dergelijks.

4 In het Oosten. 
naeder verbondt ende blykelijck contract dient geformeert te wordeu.

Soo is voor eerst gecontracteert, dat de voordaghte Hoge mogende $\mathrm{H}^{\text {ren }}$ Staten Generaell, sijn Princel $^{\mathrm{n}}$ Ex ${ }^{\text {tie }}$ ende de Bewinthebberen den seer mogende koninck van Bantam sijne onderdanen ende landen sullen helpen beschermen ende assisteren tegens alle geweldt, ongelijck ende jnvasie te water ende te landen, die hun door de Spangiaerden ende Portugesen souden mogen aengedaen worden, directelijck offte jndirectelijck.

Ende bij soo verre ijmandt [van] buijten den koninck van Bantam in sijn landt quam aendoen eenige oorlooge, sullen den capiteijn ende die gecommitteerde der Vereenighde Nederlanden, tot Bantham residerende, met alle hun volck ende maght deselve resisteren ende den koninck van Bantam assisteren, soo veell mogelyck is.

Bij allsoo verre die van Bantam jwers buijten haer landt eenige oorlooge offte jnterprijse aenvaerde, sullen de voorschreven capiteijnen offte gecommitteerde met haere maght te water offte te lande niet gehouden sijn eenigh behulp te doen.

Hierjegens zall den Hoo: Mo: koninck van Bantham ende sijne onderdanen die van de voorschreven provintien als Gelderlandt, Hollandt, Zeelandt, Uijtreght, Vrieslandt en Overyssel ende haere geallieerde, van de voorschreven provintien commissie hebbende, in sijn landt verleenen vrijhandelingh en sufficante woninge plaetse, daer hunne persoonen ende goederen in goede bewaringe mogen zijn ende deselve beschermen tegen alle ende een ijgelijck, sonder dat zylieden offte haer goederen sullen beswaerdt worden met eenige lasten, hoedanigh die souden mogen wesen.

Sall van gelycken den hooghgedaghten koninck van Bantham ende de zyne niet toelaten offte vergunnen eenige handelinge offte woonplaetse aen eenige Spangiaerden offte Portugesen offte aen ${ }^{1}$ de Europische natie, allsoo d'Ho: Mo: $\mathrm{H}^{\mathrm{rn}}$ Staten Gener ${ }^{\mathrm{l}}$, sijn Princelijcke Ex ${ }^{\text {tie }}$ ende hare capiteijnen en commissie ${ }^{2}$ in Oostindien traffiquerende met den koninck van Bantham ende sijne onderdanen nu ende ten eeuwige dage goede alliantie ende vrundtschap onderhouden, ende de voorschreven poincten in alles naerkomen ende nogh meerder, die tot vreede ende vrundschap strecken des nodigh sijnde gemaekt te worden, dewelcke bij beijde partijen gelijck deze onderteekent ende geconfirmeert sullen zijn. Tot Bantham actum ut supra.

\footnotetext{
1 Andere?

2 Commiezen?
} 


\section{Ambon.}

13 Maart 1609. 1

Frederik de Houtman, Ambons gouverneur, trachtte den invloed der Nederlanders op deze eilandengroep te bevestigen en sloot daartoe verschillende contracten. (Vgl. Tiele, Europeërs, VII, bldz. 153, v.), o. a. met verschillende dorpen op Haroekoe?

Nieuw accooord in den name van haar Hoog Mog. ende den Prince van Hollandt aen d'eene zijde, en die van Hatoeaha, ${ }^{3}$ Cabauw, + Caibolo, + ende Halalioe, ${ }^{5}$ vier negrijen op 't Eiland Oma, ${ }^{6}$ aen de andere zijde, gemaakt in 't Kasteel Victoria, in Amboina den 13 Maart 1609.

Eerstelyk, met Godes magt heeft den admiraal van de Hollanders, Steven van der Hagen, de Portugeesen in 't Kasteel Victoria in Ambon in den jare 1605 vermeestert, ende overwounen, alwaar wy negryen Hatoeaha, Cabauw, Caijlolo, ende Hoelialoe, onder haar woonende, slaven ${ }^{7}$ zyn van den Portugeesen Konink aan 't Kasteel van Ambon, gelyk wy van nu voortaan, zoo lange als wy leven, onder de gehoorzaamheid staan van haar Hoog Mog. ende den Prince van Holland, als ook den jegenwoordigen Gouverneur van 't Kasteel Amboina, Frederik Houtman; en mede by alle andere Gouverneurs, die naar hem komen, in den name van de Hooge Overheit ende den Prins van Holland.

Die van Hatoeaha, vier negryen, zulleu volgen, en ook naarkomen 't recht van den Gouverneur van 't Kasteel Ambon, doch zy zullen in haren geloove blyven, zonder dat die van 't Kasteel, nogte de

1 Overgenomen uit Valentijn, II, b, bldz. 34, v. - Deze auteur veranderde de spelling van de door hem gebruikte documenten steeds naar eigen goedvinden; en soms méér dan de spelling.

${ }^{2}$ Vgl, contract $\mathrm{N}^{\circ}$. XV.

s Het Noordelijk gedeelte van het eiland. Zie G. W. W. C. van Hoëvell, Ambon (Dordrecht, 1875), bldz. 11, 94; Valentijn, II, a, bldz. 91.

4 Kabaoe, Kailolo, aan de Westkust.

5 Hoelalioe, aan de Noord-Oostkust.

"Volgens Valentijn, II, a, bldz. 93 zijn de 4 dorpen, het "gespanschap" van Hatoeaha: Pelaoe (of Hatoeaha), Kailolo, Kabaoe en Rohomoni (aan de Westkust), maar behoorde Hoelalioe er "wel eer" óók toe.

7 Uit deze uitdrukking mag men bijna opmaken, dat het concept van dit contract in een inlandsche taal is.opgemaakt geworden, immers, wij zouden in dit verband niet van slaven hebben gesproken. 
Hollanders, 1 haar eenige overlast aandoen, of haar wegens haar geloof verjaagen zullen. Die van Hatoeaha, vier negrijen, zullen in geen christen ${ }^{2}$ negrij mogen gaan eenige moetwil drijven, of in haar boek ${ }^{3}$ lezen, of iemand Moors hebben te leeren, of lid van hare Mesdjid + maken, volgens het Moors geloof; zoo wie zulx doet, den Gouverueur zal hem straffen.

Indien iemand tegen 't Kasteel meer oorlogen, of eenige quaad aan de Hollanders. of aan die geene, die onder 't Kasteel sorteerd, wilde doen, die van Hatoeaha zullen helpen, ende de gezanten van 't Kasteel aannemen.

Wanneer den Gouverneur van 't Kasteel in Ambon met zyn teeken die van Hatoeaha, Cabauw, Caijlolo ende Halalioe zal ontbieden, om nevens andere negryen te arbeiden, of met de cora cora's 5 hier en daar met den Gouverneur, of zijn gecommitteerden te pangayen, ${ }^{6}$ zullen ten eerste met hun cora cora's, volk en geweer, volgens deze landswyze komen.

Die van Hatoeaha, 4 negryen, zullen met geen cora cora's of prauweu eenige negryen gaan beoorlogen, en ook geen andere negryen vermeesteren, of moet zulx van den Gouverneur geordineert werden.

Ende zoo de 4 negryen in Hatoeaha willen handelen, of nagels verkoopen, zullen nergens, dan aan de Hollanders aan 't Kasteel, die ter schaal brengen, ende ook zoo zy eet-waren te koop hebben, kunnen daar mede aan 't Kasteel komen handelen, en eenige dati, ${ }^{7}$ gelijk andere negrijen doen, volgens gewoonte moeten contribueeren. Voor alle welke voorverhaalde zaakeu den Gouverneur die van Hatoeaha, Cabauw, Caylolo, ende Halialoe zal helpen, gelijck als het volk van 't Kasteel en Hitoe, daaromme hebbe dit met het Tsjap ${ }^{8}$ van 't Kasteel in Ambon, ende tekening zoo van hem als van alle de Orang Kajen ${ }^{9}$ van Hatoeaha, mitsgaders met den eed bevestigt. Amen !

1 In 1617 bepaalden de Heeren XVII, dat in officieele stukken de naam "Nederlanders" en niet die van "Hollanders" gebruikt moest worden (TieleHeeres, Bouwstoffen, II, bldz. II, noot 4).

2 Dat de propaganda der Portugeezen op sommige eilanden der Ambongroep resultaten van beteekenis hadden gehad, is bekend.

3 De Koran.

4 Bedehuis der Mohammedanen.

${ }^{5}$ Koera koera: kleine roeivaartuigen.

6 Pagaaien, roeien (běrkajoeh).

7 Schatting. Vgl. Van Hoëvell, Ambon, bldz. 175 v. v.

8 Tjap: zegel.

9 Orang kaja: hoofden (letterlijk: rijke mannen). 


\section{AMBON.}

26 April 1609. 1

Ook sloot De Houtman een contract met Roemakai, aan de ZuidWestkust van Ceram. (Vgl. Tiele, Europeërs, VII, bldz. 154).

In den name Gods.

Nieuw accoord in de name van de Hooge Overigheid, ende den Prince van Holland aan de eene zyde, en de volkeren van de negry ${ }^{2}$ Roemakay, gelegen op 't groot Eiland van Ceram, gemaakt.

Dewijl de Hollanders met de hulpe Gods onze vyanden, de Portugeesen, uit de Landen van gansch Ambon verjaagd en verdreven hebben, en de Hollanders, residerende in 't Kasteel in Ambon, bewind hebben over alle Oelilima's, ende Oelisiva's, met goedheit, en in opregtheit, daarom zoo zweeren wy Orang Kajen van de negry Roemakay met een oprecht hart, en goed genoegen, dat wy willen de Hooge Overigheden, den Prince van Holland, en den Gouverneur in 't Casteel in Amboina, naarvolgen, en wy willen geen andre Heeren, of andre Hoofden anders, dan de Hooge Overigheid, ende de Prins van Holland kennen, navolgen, en helpen, gelyk alle de onderdaanen aan haren heeren doen.

Eerstelyk, zullen wy leven met onze Leere. De Amboineesen en de Hollanders zullen ons geen overlast doen wegens onze Leere. Ook zullen wy in geen Christennegry gaan, om eenige leere te doen, geen Massigit ${ }^{3}$ maken, nog ook imand Moors leeren.

Indien den Gouverneur van 't Kasteel in Amboina ons met zyn teeken ontbied, om aan 't Kasteel te helpen arbeiden, of met hem, of zijne Gecommitteerden, te pangayen, wy zullen komen, wy zullen ook, zoo den jegenwoordigen als toekomenden Gouverneur volgen of gehoorzamen.

Ende indien de Gouverneur eenige Hollanders zend, om zagoe in onze negry te koopen, wy zullen die verkoopen, en wy zullen eerst zagoe maken voor 't Kasteel, ende daarna voor andere luiden.

Wy volkeren van Roemakay, zweeren ook, dat wy met geen corra corren, of iets anders, eenige negry zullen gaan destrueeren, ook wij zullen geen negryen, 't zij Oelilima's of Oelisiva's, assi-

1 Overgenomen uit Valentijn, II, b, bldz. 35, v.

2 Nĕgari, nĕgeri: hier $=$ dorp, gemeente.

s Měsdjid. 
steren, wy zullen ook niemand zenden, noch ook de Alfoereesen ${ }^{1}$ met kost helpen, dat zy een anders volk dood slaan, of de negry afloopen, zonder last van de Gouverneur. Soo wy anders doen, den Gouverneur zal ons straffen, en de Oelilima's en Oelisiwa's zullen ons verdelgen.

Wy zullen jaarlijks dati aan 't Kasteel brengen tot teeken van gehoorzaamheid aan de hoofden, ende wij zullen aan 't Kasteel gaan handelen met zagoe, ryst, of met andere eetwaren.

Van dit alles zeg ik Gouverneur van 't Kasteel in Amboina, als gemagtigde van de Hooge Overigheid, ende den Prince van Holland, en zweere te zullen helpen, en ook oprecht recht aan de negry Roemakay te doen, gelyk aan de negryen aan 't Kasteel, Hitoe, Hatoeaha, ende aan alle Oelisiwa's, ende Oelilima's doen, daarom hebbe ik dit met 't tsjap van 't Kasteel, en met myn naam, ende de naamen, of merken der Orang Kaja's van de negry, tot teeken van onzen eed, onderteekend. Amen.

Van deze Acte zyn twee eensluidende gemaakt, de eene voor den Gouverneur van 't Kasteel in Amboina, en de andre voor de negry Roemakay.

Geschreven in 't Kasteel in Amboina op den 26 April 1609.

\section{MOJUKKEN.}

Juli 1609. ${ }^{2}$

In Februari 1609 vertrok een kleine vloot onder bevel van den viceadmiraal François Wittert van Bantam via Makassar naar de Molukken, om daar levensbehoeften en versterking te brengen, met het oog op den onzekeren toestand van ons gezag en invloed daar en tevens om Ternate en zijn aanhang tegen de Spanjaarden te beschermen. (Vgl. hiervóór, bladz. 51.) Den 23 'Juni kwam het bij Ternate, met welks sultan in de volgende maand een nader contract werd gesloten. (Vgl. Tiele, Europeërs, VII, bldz. 147, 154; De Jonge, Opkomst, III, bldz. 93-94).

Bevestingh vant contract en eeuwige verboudt, gemaeckt bij den $\mathrm{H}^{\mathrm{r}}$ admr ${ }^{\mathrm{l}}$ Frans Wittert, uijt den naem ende van wegen de Mogende $\mathrm{H}^{\text {ren }}$ Staten Gener ${ }^{1}$ der Geunieerde Landen als Hollandt, Zeelandt etc., Sijn Princelijcke Ex ${ }^{\text {tie }}$, als gouvern ${ }^{\mathrm{r}}$ derselver landen ende

1 Alfoeren. Hier bepaaldelijk de bewoners van Cerams binnenland.

2 Uit het Contractboek. 
de $\mathrm{H}^{\text {ren }}$ Bewindhebberen der Oost-Jndische Comp ${ }^{\mathrm{e}}$ ten eenre en den grootmaghtigen koninck van T'ernaten ende de tegenwoordige $\mathrm{Ed}^{\mathrm{en}}$ deser landen ter andere zijde.

Dat in alle formen ende artijkelen, gemaeckt in de $\mathrm{m}^{\mathrm{t}}$ Meyo $a^{\circ} 1607^{1}$ tusschen den E. $\mathrm{h}^{\mathrm{r}}$ admiraell Cornelis Matelieff de jonge ende Sijne Mayt, voorschreven sultan, aen wedersijde bevestight ende ouderhouden worden volcomenlijck als den jnhoudt van dien vermelt, het welcke door de Hollanders ende Zeelanders beneffens de Ternatanen op dese naervolgende manieren sal naergekomen worden.

Den Admiraell beloofft met alle zijne vermogen, de Ternatanen te helpen, haer landt, dat haer den vijandt heeft aeffgenomen offte landen hem affgeweken ende de Castelanen offte Portugesen toegevallen sijn, recouvreren ende wederomme onder subjectie ende gehoorsaemheijt te brengen.

Waertoe den Admiraell voor eerst met sijn schepen zall gaen naer de Manilhas ende Philippinos omme naer alle vermogen te beletten, dat de Casstilanen geen schepen, provisie offte toevoer herwaerts sullen senden ende den gemeenen vyand ende haer aenhangers alle mogelijcke affbreuk te doen.

Den Admiraell, sulx verright hebbende, zall hem wederom herwaerts naar Ternaten vervoegen, sonder op eenige plaetsen verder te zeijlen als in de eijlanden Manillhas, soo verre het mogelijck is en den tijt ende weder sulcx toelaet.

Onderwijlen sall den Admiraell ende zijnen raedt doen affvaerdigen eenige correcorren naer Amboijna met advijs ende brieven, naer Banda offte daer de vloote is, omme alle hullpe van schepen metten eersten hier te mogen hebben ende sall den Admiraell niet vertrecken uijt dese landen, tot Banda ende Amboijna begrijpende ", voor en alleer een ander admiraell tot ${ }^{3}$ Hollandt, Zeelandt etc ${ }^{\mathrm{a}}$ offte andere commissie van sijn Princelijcke Ex ${ }^{\text {tio }}$ ende Bewinthebberen zall gekomen zijn.

Bij sooverre eenige peijs tusschen de Hollanders, Zeelanders etc ${ }^{a}$ met de Casstilanen ende Portugesen werde gemaekt offte eenige stilstandt van wapenen voor eenigen tijt sall worden geaccordeert, zall niet mogen geschieden ofte sullen de Ternatauen ende alle ge-

1 Contraet No. XXII.

2 Zal beteekenen: hieronder begrepen Banda en Amboina.

De Jonge, III, bldz. 325, heeft "uit". 
alieerde als Ternata, Mackian, Mortier ${ }^{1}$, Sula, Cambelle, Lovoe ${ }^{2}$, Bouro, Maniphes ${ }^{3}$, Selebes, Mineau ${ }^{4}$, Taffouco ${ }^{5}$, Pangasar ${ }^{6}$, Sangi, Manado, Moro, Lolola, Gamcanor, Sebouwo, Gilolo 7, en alle andere eijlanden ende natien onder den koninck van Ternaten sorterende $^{8}$, mede met de Hollanders ende Zeelanders etc ${ }^{a}$ int zelve contract begrepen sijn en gelijck accoordt genieten.

Den Admiraell beloofft, overkomende in ons landt, sulcx grootelijcx te kennen te geven aen $\mathrm{dH}^{\text {ren }}$ Bewinthebberen, dat zij daer een armade op toerusten sullen omme de Castilanen uijt het eijlandt van Ternate te drijven.

Des geven wij de maght over in handen van de Hollanders, Zeelanders; voorts bekennen wij, dat de Hollanders, Zeelanders een schutsell [zijn] die ons beschermen. Bij soo verre sulcx geschiet, dat de heeren Bewinthebberen een vloote tot onser assistentie senden, belooven wij ende zweeren de Hollanders niet te verlaten; d'onkossten die hier op gedaen zijn, belooven wij alle wat in ons vermogen is te voldoen, soo wij ${ }^{9}$ in handen, totter tijt toe dat wij reekenen, wadt onkossten beloopen sullen, alle de tollen van de jnwoonders ende vreemdelingen in handen van de Hollanders, Zeelanders, etc ${ }^{\mathrm{a}}$, omme haer daerzelffs mede te betalen ende vorders van alle tollen te bevrijden.

Waerover wij inwoonders ende alle onse ondersaten belooven, zooals die verstroijt zijn op andere plaetsen in vreemde landen, soo haest bij een te vergaderen uijt alle plaetsen die den Koninck toegedaen zijn, als mogelijck is, om met gelijcker handt de Castilanen te verdrijven, soo niet, verwaghten UE. aller assistentie.

Des sullen wij niet vermogen, met andere natien ons nagelen mogen verhandelen, alleen bij den koopman, die de Hollanders,

1 Moti. Dit eiland was door Wittert met een Nederlandsche versterking voorzien bij deze gelegenheid.

${ }^{2}$ Loehoe op Klein-Ceram.

3 Manipa.

"Valentijn, I, b, bldz. 231 heeft "Meau", wat is Majoe, een eilandje ten Noordwesten van Ternate.

${ }^{5}$ Valentijn heeft "Taffoero", wat is Tifore, een eilandje ten Noordwesten van Ternate.

${ }^{6}$ Een andere naam voor Tagoelandang.

7 Moro, Lolola, Gamkanora, Saboew (Saboego of Sawoe?) en Djailolo, alle op Halmaheira.

8 Het is bekend, dat de vorst van Ternate nog in die dagen ver buiten de eigenlijke grenzen van zijn gebied gezagsrechten pretendeerde.

9 Valentijn, t. a. p., bldz. 232, heeft: Zo geven wij hen in handen. 
Zeelanders etc ${ }^{n}$ gestelt hebben, op dat UE. namen in ons landt magh vermeerderen; ende den prijs die bij den Koninck ende den Admiraell sullen geraemt worden, sullen wij jnwoonders gehouden zijn te accepteren.

Oock dat de Hollanders, Zeelanders ende wij Ternatanen in alles zouden met malcanderen over een komen; voorts en zullen niet vermoogen, de Hollanders over de Ternatanen eenigh reght offte justitie te doen, voor all eer sij het den raedt van de Ternatanen te kennen geven hebben, desgel ${ }^{x}$ soo haer de Hollanders te buijten gingen, sullen haer de Ternatanen niet mogen justiceren, voor alleer sij den raedt van de Hollanders, Zeelanders te kennen gegeven hebben.

Oock malcanderen niet in gelooffs zaken te berispen ofte bespotten. Offt geviell, datter eenige Hollanders, Zeelanders etc. wilden bij u loopen om het Moorsch gelooff aen te nemen, zullen gehouden wesen die gewilligh in handen van de Hollanders, Seelanders haer justitie over te leveren, desgel ${ }^{\mathrm{x}}$ soo eenige Ternatanen Christen wilde worden, sullen haer in de justitie van de Ternatanen haer handen leveren.

Mede dat den koningh van Ternate beloofft, met d'aldereerste commoditeyt offte mousson sall een offte meer correcorren aff doen vaerdigen naer Loehoe en Combello met een overste uijt de naem ende van wegen de Heeren Staten Generaell van Hollandt, Zeelandt, Sijn Princel $^{\mathrm{n}} \mathrm{Ex}^{\text {tie }}$ ende zijne Mayesteyt van Ternate, om de inwoonderen van dito plaetse vooren te houden het eeuwigh verbondt, 't geene tusschen de Hollanders, Zeelanders etc ${ }^{\mathrm{a}}$ ende zijne May ${ }^{\mathrm{t}}$ van Ternate is gemaeckt ende bevestight, waertoe sall authoriseren eenige bequame persoonen van wegen Sijne $\mathrm{May}^{\mathrm{t}}$ voorschreve met volkomen authoriteijt ende commissie om alles te doen effecturen ende in onderdanigheijt te houden; daer beneffens de $\mathrm{H}^{\mathrm{r}}$ admiraell met synen raedt van wegen de Hollanders, Zeelanders etc ${ }^{a}$ mede sall seynden ende authoriseren eenen Adriaen Corsen ${ }^{1}$ offte alsulcke persoonen als Sijne May ${ }^{t}$ van Ternaten met den raedt der Hollanders etc $^{\mathrm{a}}$ sall verdragen ende des noodts sijnde een fortresse maeken, 't zij op Louhoe offte Combello ${ }^{2}$ tegen den aenstoot der vijanden. Dat de Hollanders ende Zeelanders met den morgenstont ${ }^{3}$ koninck

1 Adriaen Corssen was in 1609 en 1610 commandant van Takome (Willemstad) op Ternate, (De Jonge, Opkomst, III, bldz. 274, 396).

2 Loehoe aan de Oost-, Kambeloe aan de Westkust van Klein-Ceram (Hoeamoeal), dat stond onder de heerschappij van de Sultan van Ternate, die hier een stadhouder had in deze tijden.

$s$ Een zonderlinge schrijffout voor "mogensten" (Vgl. Valentijn, t. a. p., bldz. 233). 
van Ternaten ende sijne geallieerde vrunden ende vasalen sullen verbonden ende gehouden wesen ende mits desen verbinden, t'onderhouden ende te doen onderhouden een eeuwige verbintenisse van vriendschappe, conversatie, handell en commercie ende dat Sijne $\mathrm{May}^{\mathrm{t}}$ ende de Hollanders ende Zeelanders voornoemt aen Sijne May t'allen tijde sullen geven alle hulpe, faveur ende bystandt, ende te helpen defenderen naer alle haer vermogen tegens elcx ende een ygelijck ouser vijanden, die aen Sijn May ${ }^{\mathrm{t}}$ offte aen de Hollanders, Seelanders voornoemt in eenige manieren souden soeken offte traghten t'offenceren offte te beschadigen, hetwelck in aller voegen de Hollanders ende Zeelanders voornoemt gelijck oock Sijne May ${ }^{\mathrm{t}}$ ende alle haere vasalen, vrunden ende geallieerde sullen verbonden blijven t'onderhouden ende defenderen. 't Selve boven verhaelt is onder verbintenisse van getrouwigheijt, eere ende woordt, die wij beijde aen Godt ende onse eveunaessten schuldigh zijn.

Aldus gedaen in de stadt Malayo offte sterckte Orangie ', leggende opt eylandt Ternaten in de Moluccos in de maent van Julij A ${ }^{0} 1609$ ende was onderteykent met Arabische letteren uijt den naem van den Koninck. Onderstondt Frans Wittert, Cornelis Leendertszoon Crackel ${ }^{2}$, Adriaen Wouterszoon en Pieter Gerritszoon.

\section{AMBON.}

\section{Augustus 1609. ${ }^{3}$}

Misschien met het oog op den last der Bewindhebbers, overal de contracten in den Archipel te hernieuwen (zie hiervóór, bldz. 56), deed Frederik de Houtman dit met het verdrag met Hitoe van Februari 1605 , (Vgl. De Jonge, Opkomst, III, bldz. 209, v.). Alleen de slotalinea, welke deze bekrachtiging behelst, laat ik hier volgen 4 .

Dit verbondt ende vast accoordt hebbe ick $\mathrm{Cap}^{\mathrm{t}}$. Hittoe met de orankayen verniewt ende weder op een ${ }^{5}$ geapprobeert ende onder-

1 De Nederlandsche versterking bij Malajoe.

2 De Jonge, t. a. p., bldz. 327, enz. heeft Crackeel; Valentijn, t. a. p., bldz. 232 heeft Crakkel.

$s$ Uit het Contractboek.

4 Valentijn, Ambon, b, bldz. 30, stelt deze bekrachtiging foutief in 1605 . Vgl. óók b, bldz. 33, kolom 2, alinea 2.

5 Valentijn, t. a. p., heeft: "op een nieuw". 
teekent, jn presentie van den gouvern ${ }^{\mathrm{r}}$. Frederick Houtman jnt casteell Amboina den $10^{\text {en }}$ dagh van de mane Jonnadell Alball ${ }^{1}$ jnt jaer Mahomet 1019. Is $\mathrm{A}^{0}$ Christij den 9 Augustij 1609.

\section{BANDA.}

\section{Augustus 1609. 2}

Zooals bekend is, hadden Bewindhebbers der O. I. C. aan Verhoeff opgedragen, met het oog op de mogelijkheid van een bestand met Spanje op den grondslag van het uti possidetis in het Oosten, zooveel mogelijk overeenkomsten met de verschillende streken van het Oosten aan te gaan: „ende voornaementlyck so recommandeeren wij Ul. de plaetsen van de Moluques ende eylanden van Banda op 't allerhoochste". Verder "souden" de Bewindhebbers "goetvinden", dat „op de principaelste plaetsen daer aliantie en vruntschappe" gemaakt werd, "met wille van de Indianen eenich fort" werd opgericht, "opdat wy deselve plaetsen met meerder verseeckertheit mochten houden ende ook voor onse plaetsen mochten verdedigen ende den handel van deselve plaetsen alleen voor ons behouden en de Portugeesen ende anderen daaruyt houden". En verder: "Wij seggen andermael dat dese landen ende de Comp. meest aen de Molueques ende eylanden van Banda is ghelegen, daerom sult deselve plaetsen boven en voir alle anderen sien te verseeckeren." En later nog: „De eylanden van Banda ende Moluques is het principale wit, waarnaer wij schieten.... Wij kunnen U.E. niets gewisser ordonneren, dan alleenlyck op 't hoochste recommanderen de eylanden, daer de naghelen mette nooten en de foelie groeijen, deselve soeckende met tractaet ofte met geweld aen de Comp. te verbinden vóór den 1 September 1609 ofte eerder, oock op elck land een klein fortres opwerpende en met eenich krijchsvolk besettende." Verhoeff ging van Bantam naar Banda, om deze opdracht te volvoeren. Natuurlijk dat de Bandaneezen volkomen afkeerig waren van het plan der Nederlanders, een versterking op hun land op te richten, met de bedoeling natuurlijk, om de Bandaneezen geheel aan de handelspolitiek der O. I. C. vast te snoeren. Maar de macht waarmee Verhoeff kwam (April 1609), was te sterk en toen zij zagen, dat deze van plan was, de zaak door te zetten, ook tegen hun zin, gaven zij toestemming. Het fort zou gebouwd worden op Neira. Maar de Bandaneezen hadden slechts gedwongen toegestemd in de eischen der Nederlanders. Dit strekt tot verklaring van den verraderlijken moord op Verhoeff en een aantal der zijnen: de dieper liggende oorzaak ervan is het optreden van de O. I. C. De vijandelijkheden, welke thans volgden, leidden ten slotte tot onderstaand contract, door Verhoeven's opvolger, Simon Janszoon Hoen, gesloten met de Bandaneezen. (Vgl. De Jonge, Opkomst, III, bldz. 307-312, 94-101; Tiele, Europeërs, VII, bldz. 148-153; Van der Chijs, Bandaeilanden, bldz. $36-52$.)

1 Djumádi'lawal. - De Mohammedanen rekenen bij maanjaren.

2 Uit het Contractboek. 
In den name, dat is met aenroepinge, van den eenige waeraghtige Godt, Scheppers des hemels ende der aerden, soo hebben de seer Hoog Mogende $\mathrm{H}^{\text {ren }}$ Staten Generaell der vrije Geunieerde Nederlandsche Provintien ende den doorlughtigen hooghgebooren vorst Mauritius, geboore prince van Orangien, grave van Nassou ende Gouvern $^{\mathrm{r}}$ van deselve provintien, admir genr $^{\mathrm{l}}$ van de zee, mitsgad ${ }^{\mathrm{s}}$ de Bewinthebberen van de Geoctroyeerde Oost Jndische Comp ${ }^{\text {e }}$ ter eenre ende de seer vermaerde orancaijen van alle ${ }^{1}$ de eijlanden, steden ende leden van gansch Banda ter andere zijde, met malcanderen gem $^{t}$ een eeuwigh verbondt en onverradelijcke ${ }^{2}$ broederlijcke vrundschap, in vougen dat de orangcaijs ende ondersaten van haer respective van de selven staen ende resorteeren onder het fordt Nassou.

Ten tweede belooven de voorschreven $\mathrm{h}^{\text {ren }}$ orangkaijs eenige ${ }^{3}$ specerijen in dese landen vallende sullen leveren offte verkopen offte verhandelen aen de gecom ${ }^{\text {de }}$ van de voorschreven $\mathrm{H}^{\text {ren }}$ Staten vant fordt Nassou, sonder aen eenige andere persoonen ofte natien als de voorschreven gecommitteerden eenige specerijen int minste offte meeste te moogen verkoopen, verhandelen offte verruijlen.

Ende jngevalle de voorschreven orankaijs eenige specereijen voor eenige vivres aen eenige Indianen ${ }^{4}$ offte andere verruijlden, 't welck sij vermogen to doen met consent van den Gouvern ${ }^{\mathrm{r}}$, onder conditie dat de voorschreven Jndianen ${ }^{5}$ ende andere Javanen ${ }^{6}$ deselve specerijen wederom aen 't cassteel Nassou sullen moeten verkoopen, alle joncken sullen gehouden wesen te anckeren ondert commandement van 't geschut van 't casteel op de rheede voor Campo 7 Java.

Alsoo de landen ende dorpen van 't eijlandt, daer 't cassteell Nassou op leij, ${ }^{8}$ met de wapenen geconquesteert is ende dat door oorsaeke van de moordt van den admiraell Verhoeven zall ${ }^{\mathrm{r}}$, soo ist

1 Dit is volkomen onjuist: o. a. poeloe $\mathrm{Ai}$ en poeloe Roen zijn zeker niet tot dit contract toegetreden. (Van der Chijs, t. a. p., bldz. 51.)

2 "Onveranderlycke" in andere exemplaren van het contract.

3 In het exemplaar bij De Jonge, Opkomst, III, bldz. 315-316, staat „ alle speceryen".

"Bij De Jonge: „Javanen”.

5 De Jonge: „Javanen".

${ }^{6}$ De Jonge: "Indianen".

7 De Jonge: "Kampong Java". Na "moeten verkoopen" heeft De Jonge nog: „ofte vermangelen, sonder deselve (sonder consent van den Gouverneur) te mogen vervoeren ofte vercoopen."

8 Het eiland Banda Neira (Vgl. Tiele, Europeërs, VII, bldz. 152, 153; De Jonge, III, bldz. 99.) Tiele vergist zich, als hij zegt: „De geheele archipel beette als veroverd land in 't bezit der Hollanders te komen". 
dat het selve eijlandt ten dienste van de Ed ${ }^{l e}$ Mogh. H ${ }^{\text {ren }}$ Staten Generael en sijn Princel. Ex ${ }^{i e}$ ende de Bewinthebberen der Generaele Vereenighde Oosstjndische Comp. eeuwelijck ende erffelijck sall worden gehouden, sonder dat de heeren ende oranghkaijs van Banda daerop eenige actie sullen mogen pretendeeren, ten waere de Heeren Staten daer anders jn disponeerden.

Vorder belooven wij ende sweeren wij bij eede uijt ten name ende van wegen d Ed ${ }^{\mathrm{e}}$ Moghende $\mathrm{H}^{\mathrm{re}}$ Staten Gener ${ }^{\mathrm{l}}$, Sijn princelijcke $\mathrm{Ex}^{\text {tie }}$ ende Bewinthebberen der Generaele Vereenighde Oost Jndische Comp $^{e}$, de Bandaneesen alle hulpe endè assistentie te bewijzen ende haer te beschermen tegen alle Portugesen ${ }^{\mathbf{1}}$ over lant offte hinder souden soeken aen te doen.

Oock belooven wij alle Bandaneesen te vergunnen, dat zij met haer joncken sullen mogen vaeren ende traffijqueren op alle plaetsen daert hun believen zall mits dat zij geen specerijen sullen mogen vervoeren.

Ende sullen mede, om van d'onsen in zee zijnde niet beschadight te worden, van den gouvern' ${ }^{\mathrm{r}}$ van 't fort Nassou paspoort versoeken, die hij de voorschreven Bandaneesen om haer versoek sall geven.

Voorder belooven wij alle overloopers, die van haar meesters de Bandaneesen om eenigh quat feijt offte andersints zouden mogen overkomen, aen de voorschreven Bandaneesen wederom te geven, sonder deselve te mogen behouden; waertegen de voorschreven Bandaneesen jnsgelijex gehouden sullen wesen, alle die personen die van onse aen haer sijde sullen overloopen, wederom jn handen van den gouvern ${ }^{\mathrm{r}}$ van 't cassteell Nassou te leveren, sonder deselve te mogen behouden, besnijden offte Moors maeken.

Welcke poincten ende articulen alle, ook wes meer tot voltreckinge van een eeuwigh verbondt ende broederlijcke vrundschap gerequireert ende dienstigh bevonden sall worden, de hooghgeaghte ende seer mogende partijen reciproquelijck op coninclijcke ende vorstelijcke woorden belooven te sullen presteren en naerkomen, als off deselve in desen pertinentelijck uijtgedruckt waren, sonder dat de mesusen ofte fauten, [die] bij eenige van beijde partijen onderdane jègens dit eeuwigh verbondt ende broederlijcke vriendtschap begaen moghte worden, deselve in craght sullen mogen veranderen offte te niet doen, maer sall den geoffenseerde sijn klagh doen, daer onder de misdader sorteert, naer uijtwijsen der borgerlijcke, goddelijcke ende

1 De Jonge: „ende anderen die haer eenige overlast", enz. 
natuerlijcke wetten, soo haest doenlijck sall zijn te reght geholpen ende de misdoenders naer vigeur van justitie ende gelegentheijt der saecken op 't hooghste te straffen offte in handen van den gegraveerden te selven fijne overgelevert werden, om all soo den geoffenceerden van overlast te ontledigen ende onderlijcke vriendtschap soo langs soo meer te doen nemen.

Aldus ter eeren Godes ende de gemeene welvarende ruste [van] beijde landen ende steden onder geaccordeert ende beslooten door den $\mathrm{H}^{\mathrm{r}}$ Symon Janszoon Hoen, viceadmiraell van de vloote van Hare Mogende $\mathrm{H}^{\text {ren }}$ Bewinthebbers, daertoe geauthoriseert, blijckende bij de brieven van credentie, haere mog. heeren orancays vertoont met belieffte van deselve haere $\mathrm{May}^{\mathrm{t}}{ }^{1}$ met de eerste gelegentheijt te doen in amplissima forma den jnhoudende deses vervattende onder den grooten zeegell van Haere Mogende $\mathrm{H}^{\text {ren }}$ Staten ende sijne princelijcke Ex ${ }^{\text {tie. }}{ }^{2}$

Gedaen jnt schip Hollandia liggende in de eijlanden van Banda desen $10^{\text {en }}$ Augustij $A^{\circ} 1609$.

\section{JAPAN.}

25 Augustus 1609. ${ }^{3}$

De eerste aanrakingen der Nederlanders met Japan dagteekenen van 1600 , toen het schip de Liefde van de vloot van Jacques Mahu en Simon de Cordes op Kioeshioe landde en enkele onzer landgenooten dáár gevestigd bleven. Onder hen Melehior van Santvoort en Jacob Janszoon Quaeckernaeck. Deze, voorzien van een - niet bewaard gebleven handelspas voor de Nederlanders, begaven zich in 1605 naar Patani aan de Oostkust van het Maleische schiereiland en Quaeckernaeck ging van daar naar Djohor, waar hij in 1606 de vloot van Cornelis Maetelieff ontmoette ${ }^{4}$. Zoo werd de aandacht der onzen meer op Japan gevestigd en van onze factorij in Patani uit werden sedert 1608 ter wille van den handel nieuwe aanrakingen met genoemd rijk gezocht. Ook de Bewindhebbers der O. I. C. zagen deze gaarne. In Juli 1609 kwamen twee

1 De zin is hier blijkbaar bedorven.

2 Dit niet zeer duidelijke slot wordt niet aangetroffen in het exemplaar bij De Jonge, t. a. p., bldz. 316.

$s$ Overgenomen uit Lauts, Japan, bldz. 171. Ik heb deze lezing gebruikt, omdat zij is "de letterlijke vertaling" van het origineel, „bij de faktorij op Dezima voorhanden" (later in het Rijks-archief geplaatst), welke vertaling aan Lauts is megedeeld "van wege den Minister van Koloniën." De Jonge, Opkomst, III, bldz. 301, heeft een andere lezing. De hoofdinhoud verschilt echter niet. (Vgl. De Jonge, t. a. p., bldz. 293, v.).

${ }^{4}$ Vgl. hiervóór, bldz. 41. 
Nederlandsche schepen, de Roode (of Vereenigde) Leeuw met Pijlen en de Griffioen, te Hirado (Firando). Abraham van der Broeck, Nicolaas Puijck en Melchior van Santvoort werden naar den beheerscher van het rijk ${ }^{1}$ gezonden, om een verdrag te sluiten. Ofschoon dit doel niet werd bereikt, werd hun toch handelsvrijheid verleend bij onderstaanden pas. Een Nederlandsche factorij, onder leiding van Jacques Specx, werd te Hirado opgericht. (Vgl. L. C. D. van Dijk, Van Berchem-Japan, b, bldz. 1-32; De Jonge, t. a. p., bldz. 85-87, 299-301; Nachod, Japan, S. $99-116)$.

Wanneer de Hollandsche schepen op Japan varen, in welke bogt zij ook mogen landen, zoo mag men deselve niet te keer gaan.

Voortaan zal men dit besluit houden, en zonder van deszelfs zin af te wijken, hen gaan en komen laten.

Aldus is 't kortelijk onze rondborstige wil geweest.

Het $14^{\text {de }}$ jaar Kerisjoo, 2 op den $25^{\text {sten }}$ dag van de $7^{\text {de }}$ maand

(25 v. Oogstmaand 1609) aan

Tjsaks Koeroenheike. ${ }^{4}$

\author{
Zegel \\ van den Sjoogoen
}

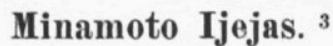

\section{AMBON.}

\section{Augustus 1609. 5}

Van Banda begaf Hoen (zie hiervóór, bldz. 66) zich naar de Ambongroep, waar hij 21 Augustus 1609 aankwam. Ook hier werden de verhoudingen door een nieuw contract geregeld. (Vgl. De Jonge, Opkomst, III, bldz. 102; Tiele, Europeërs, VII, bldz. 15̇3). Het contract van Februari 1605 was reeds 9 Augustus 1609 door toedoen van De Houtman bevestigd geworden ${ }^{6}$.

1 In die dagen was de Mikado de titulaire, de Shogoen de feitelijke beheerscher van Japan. Eerstgenoemde resideerde toen te Miado (thans Kioto); laatstgenoemde te Yedo (Tokio). Shogoen was toen Iyeyasoe, de stichter der Tokoegawa-dynastie, die tot 1868 is blijven voortleven. (Vgl. o. a. Nachod, Japan, S. 118 ff.)

${ }^{2}$ Lees: Keitsjo of Kecho, een jaarkring (Nengo), die begint met 1596 (en loopt tot 1614).

3 Iyeyusoe.

${ }_{4}$ Over wien met dezen naam bedoeld wordt en den verderen strijd, waartoe deze pas aanleiding heeft gegeven, zie men Lauts, t. a. p., bldz. 171, v.; Van Dijk, t. a. p., bldz. 28, v., 40; De Jonge, t. a. p., bldz. 293, v.; Nachod, t. a. p., S. XVII-XIX. Vgl. ook hierna, bldz. 95, noot 1 .

${ }^{5}$ Uit het Contractboek.

6 De Jonge, bldz. 102, vergist zich, als hij zegt, dat deze bevestiging plaats had na de komst van Hoen: immers deze is eerst 21 Augustus 1609 bij de Ambon-eilanden gekomen. Vgl. ook Valentijn, Ambon, b, bldz. 33. Zie ook hiervóór, contract $\mathrm{N}^{\circ}$. XXIX. 
Accoordt met den Vice-adm Symon Janszoon Hoen ende de voorschreven capiteijn ende orangkaij van Hitoe.

Verbondtschrifft van de orangkaijs van Louhoe, Combello, Lissijdij met ook den orangcaij Basie ${ }^{1}$ als ook den cap $^{t}$ Hitoe ter eenre ende den vice-admiraell Symon Hoen ende Fredrick Houtman, gouver $^{\mathrm{r}}$ van Amboyna, ter andere zijde.

Eerstelijck sullen de Christenen eude de Muhammeddanen ${ }^{2}$, dogh en sullen den anderen niet molesteren.

Ten anderen soo wie ondert cassteel van Amboyna staet, sullen onder de Hollanders blijven ende wie onder Hitoe staet, sullen onder Hitoe blijven ende mede die onder Lissijdij ende Combello staet, sall onder Combello ende Lissijdij blijven ende off geviele ymandt onder sijn hoofden niet willde staen ende hem begrepe, 't zij die onder de Hollanders, onder Hitoe, Louhoe, Combello ende Lissijdij staen, ${ }^{3}$ sullen de Hollanders mitsgaders die van Hitoe, Louhoe, Combello, Lissijdij gehouden sijn, malkander d'all sulcken te reghten ende straffen ondert reght van sijne hooffden.

Ten derden sullen de Hollanders op ons landt sonder consent geen casteel offte t' fort moge mogen maeken, soo lange wij in de eenige ${ }^{+}$vrindschap sijn.

Ten vierden soo daer eenige van onse vier steden wegh liepen onder 't gebiedt van den Gouvern ${ }^{\mathrm{r}}$, sall deselve ende ons weder leveren, op dat sulcx niet meer en doen, als mede soo ymant daer van des Gouvern ${ }^{\text {rs }}$ gebiedt wegh liepe ende in eenige onser vier steden quamen sonder consent van den Gouvern ${ }^{r}$, sullen wij denselven wederleveren.

Ten vijffden sullen allen de nagelen aen de Hollanders moeten

1 De Jonge, III, bldz. 102, 317, denkt hierbij aan „Orang-kiai van Basia of Manipa". Tiele, Europeërs, VШ, bldz. 153, noot 1, zègt: „Hoogstwaarschijnlijk is evenwel Kimelaha Bassi, de vertegenwoordiger des Sultans van Ternate bedoeld", en hij verwijst daarbij naar Valentijn, Ambon, b, bldz. 34 . De bladzz. 19, 22, 33 en 37 van dit gedeelte van Valentijn bevestigen m. i. deze meening, dat men hier heeft te doen met den orangkaja Bassi Frangi, zooals Valentijn hem noemt, den stadhouder (kimalaha of salahakan) van den sultan van Ternate op Klein-Ceram.

2 Wat hier vergeten is in de kopie, kan worden aangevuld uit Valentijn, t. a. p., bldz. 33: „sullen de Christenen Christenen en de Mohammedanen Mohammedanen blijven, dogh" enz.

3 En dus onder den sultan van Ternate, die Klein-Ceram onder zijn gezag had.

4 Eenige? 
gelevert worden, waervan nu geene vasten prijs gemaekt is, maer waghten opt gebodt van onsen koninck van Ternaten ${ }^{1}$, twelck sulleu alle gelijckelijck volcomentlijck naerkomen.

Dit accoordt van den gouverneur en viseadmiraell voorschreven is gedaen uijt den namen van de $\mathrm{H}^{\text {ren }}$ Staten Generaell en sijn Princel. Ex ${ }^{\text {tie }}$ in Hollandt op Woonsdagh, 25 $5^{\mathrm{e}}$ dag van de maen Jom vadillavall 2 jnt jaer Muhammed 1019. A ${ }^{\circ}$ Christij $26^{\text {e }}$ Augusty 1609.

Onderstaand schrijven van de hoofden van Loehoe, Lesidi, Kambeloe en van den kimelaha Basi aan den sultan van Ternate staat in verband met bovenstaand contract.

Wij ondersaten van Loehoe, Lissijdij, Combello, als ook alle de Olisives ende Olilimes van dien, met orangkay Basy doen reverentie aende voeten ende bidden Godt, hij UE May ${ }^{3}$ een langhduyrigh leven will verleende.

Voorder is de reverentie van Basij ende wij, UE onderdanen, om UE Maijt te kennen te geven, hoe dat den viceadmiraell Symon Hoen ende Fredrick Houtman, gouvern ${ }^{\mathrm{r}}$ vant casteell Amboijna, aen ons, UE Maijt onderdanen, aen 't Casteell ontboden heefft, daer wij alle gecompareert hebben; soo ist dat den Viceadmirl ende Gouvern $^{\mathrm{r}}$ versoght hebben, om het oude accoordt te vernieuwen, dat tusschen de Hollanders ende UE Maij ${ }^{t}$ onderdanen gemaekt is, waerop UE Maijt onderdanen gemaeckt hebben, wij 't selve door vreese Uwer Maij ${ }^{t}$ niet over ons nemen, want het geen manier is, dat de ondersaten voor haeren $\mathrm{H}^{\text {ren }}$ gaen. Noghtans door het versoeken ende aenstaen van den Viceadmir ${ }^{1}$ ende Gouvern ${ }^{\mathrm{r}}$, soo doen wij UE Maijt weten, dat wij alle ons submiteeren ende volkomen wille ende sullen naerkomen 't verbondt 't geene tusschen U ende den Prince van Hollandt gemaeckt hebt. Op een Maendagh $5^{\text {e }}(?)$ mane Jom vadlelva jnt jaer Mahomet 1019 ; A $^{\circ}$ Christy $25^{\mathrm{e}}$ Augustij 1609. Was onderteekent aldus.

\section{Dit geschreven bij iman + LokLoN.}

1 Een bewijs, dat ook Hitoe den sultan van Ternate als zijn opperheer erkende, ten minste wanneer dit zoo te pas kwam, in dit geval om achter des Sultans toestemming zich te verschuilen tegenover de vorderingen der Nederlanders.

2 Djumádi'lawal.

3 De sultan van Ternate.

"Imâm = voorganger in het gebed, een Mohammedaansche z.g. "geestelijke". Vermoedelijk de imâm van Loekoe. Zie Begin ende Voortgang (Verhoeven) bldz. 198. 


\section{BORNEO'S WESTKUST.}

1 0ctober 1609 '.

Nadat reeds eenige jaren vroeger (waarschijnlijk in 1606) de OostIndische Compagnie een factorij had opgericht te Soekadana (waarmede men reeds in 1604 was in aanraking gekomen), kwamen de Nederlanders in 1609 in aanraking met Sambas, hetwelk onder Djohors suprematie stond, en dat Landak en Mĕmpawa tot zijn gebied rekende. Nu werden van Landak de meeste diamanten aangevoerd te Soekadana; maar de vertegenwoordiger der O. I. C. dáár, Samuel Bloemaert, was van meening, dat Sambas voor dien diamanthandel beter geschikt zou zijn. De vorst van Sambas had ooren naar het plan, om dien handel van Soekadana naar zijn land te verleggen en sloot met Bloemaert het volgende contract. (Vgl. Van Dijk, Borneo, bldz. 130-137; Tiele, Europeërs, VII, bldz. 130,159, v.)

Eeuwig verbondt ende contract van wegen d'Hoog Mogende $\mathrm{H}^{\text {ren }}$ Staten Gener ${ }^{1}$ der Vereenigde Nederlandsche provintien, Zijne Princelijcke Ex ${ }^{\text {tie }}$ ende de $\mathrm{H}^{\text {ren }}$ Bewinthebberen van de selve landen, traffijquerende op Oostindien, ter eenre ende den doorlughtigen koninck ${ }^{2}$ van Sambas ende omliggende plaetse op 't eijlandt Borneo, ter andere zijde gemaeckt ende vastelijck beslooten het naervolgende.

In den eersten is gecontracteert dat de voordaghte Hoog Mogende $\mathrm{H}^{\text {ren }}$ Staten Generaell, Sijn Princelijcke Ex ${ }^{\text {tie }}$ ende de Bewinthebberen den seer mogende koninck van Sambas sijne onderdanen en landen sullen helpen beschermen tegen alle geweldt, ongelijck ende jnvasatie $^{3}$ te water ende te lande die hem door de Spangaerden ende Portugesen souden mogen aengedaen worden.

Ende bij soo verre ijmandt van buijten den Koninck in sijn landt quamen aendoen eenige oorlogh, sullen de capiteijns ende gecommitteerde der Vereenighde Nederlanden tot Sambas residerende met alle hun volck ende maght deselve te resisteren ende den koninck van Sambas assisteren soo veell mogelijck is.

Bij soo verre die van Sambas ijwers buijten haer landt eenige oorloge offte jnterprijse aenvaerden, sullen de voorschreven capi-

1 Uit het Contractboek. De lezing bij De Jonge, Opkomst, III, bldz. 302304 , luidt in den aanhef en aan het slot iets anders.

2 Bij De Jonge luidt de onderteekening: "Saboa Tangan Pangeran Ayde Pae Sambas". Hierin ligt zeker de titel: Pangeran Adipati opgesloten. (Vgl. Van Dijk, Borneo, bldz. 137).

s De Jonge, bldz. 303: „invasie". 
teijnen offte gecommitteerden met haer maght te water ende te lande niet gehouden sijn eenigh behulp te doen.

Hier tegens zall de zeer mogende koninck van Sambas ende zijne onderdanen, waeronder begrepen wordt Mamphaua, Landa ${ }^{\mathbf{1}}$ ende andere landen die onder sijn gebiedt staen, die van de voorschreven provintien commissie hebben, ${ }^{2}$ in zijn landt verleenen vrije handelinge ende suffisante woonplaetse ende vastigheijt, daer hunne persoonen ende goederen in goede bewaringe mogen sijn ende deselve beschermen tegen alle ende een ygelijck, sonde ${ }^{3}$ dat sij lieden offte haere goederen sullen beswaert worden met eenige lasten, maer haere goederen vrij uijt en jnvoeren sonder eenige toll offte andere ongelden te betalen. Desgelijex sall den voornoemde koninck de geene, die de commissie van de voornoemde provintien hebben, vrij in alle sijn landen laten handelen als Mamphava, Landa ende voorts heell tot de willden, ${ }^{+}$daer de diamanten gevist worden, sonder dat van sijn ondersaten deselve enige verhinderinge offte overlast gedaen sall worden.

Sall dan gelijck ${ }^{5}$ den hooggedaghten koninck van Sambas ende de sijne niet toelaeten offte vergunnen eenige handelinge offte woonplaetse aen eenige Spangiaerden, Portugesen, Engelsen, Franschen offte eenige andere Europische natien. Van gelijcken sal den voorgedachten kooninck van Sambas geen diamanten uijt sijn landt laten voeren door sijn jnwoonders offte eenige vreemde natien, die jn sijn landt souden mogen traffiqueren, maer alle deselve aen de geene die de commissie van de voorschreven provintien hebben tot een redelijcke prijs verkopen.

Ende bij sooverre die (van) Landa, desgelijex de willden, daer de diamanten gevist worden, tot Sambas willen komen handelen ende Sulcken dona ${ }^{6}$ verlaten, sullen de geene die de commissie van voorschreven provintien hebben, haer huys aldaer oock opbreken ende in Sambas komen, alsoo op twee plaetsen wonende alltijt oorloogen tusschen de koningen van Sambas en Suckedano soude opstaen.

1 Měmpawa, Landak.

2 De Jonge, bldz. 302: „die van de voorn. provintien, als Gelderlant, Hollant, Zeelant, Uytrecht, Vrieslant ende Overijssel en haere ghealieerden van de voornoemde provintiën commissie hebben", enz.

3 Moet natuurlijk zijn: "sonder".

4 De Dajaks. - Sambas werd bestuurd door een Maleisch Vorstenhuis.

"Moet zijn „van gelijeken". (Zie De Jonge, t. a. p., bldz. 503).

- Moet natuurlịk zijn „Suckadana”, zooals De Jonge heeft. 
Sullen de Hoog Mogende $\mathrm{H}^{\text {ren }}$ Staten Generaell, Sijne Princelijcke Ex ${ }^{\text {tie }}$ met sijne capiteijnen ende commijsen, in Oostjndien traffiquerende, met den koninck van Sambas ende zijne onderdanen nu ende ten eeuwigen dage goede alliantie ende vrundschap onderhouden ende de voorschreven poincten in alles naerkomen ende nogh meerder die tot vrede en vrindtschap strecken, des noodigh sijnde gemaekt te worden, dewelcke bij beijde partijen gelijck desen onderteijkent ende geconformeerdt sullen zijn.

- Actum tot Sambas desen $1^{\text {e }} 8^{\text {ber }} A^{\circ} 1609$ ende was onderteijkent, den naam van de Koninck in Arabische letteren ${ }^{1}$ ende uijt den naem van de Hoog Mogende $\mathrm{H}^{\text {ren }}$ Staten Generaell, Sijne Princel. Ex $^{\text {tio }}$ ende $\mathrm{H}^{\text {ren }}$ Bewinthebberen der Vereenighde Oostjndische Comp. Samuel Blommaert.

\section{MOLUKKEN.}

10 December 1609. ${ }^{2}$

Van Ambon begaf Hoen zich naar de Molukken in September 1609. Met behulp der Ternatanen verdreef hij in November de Spanjaarden van het eiland Batjan, waar hij in het thans Barneveld gedoopte Spaansche fort een garnizoen legde. Met den sultan van Batjan, die geen partij had gekozen in den strijd, werd nu een contract gesloten, waarbij ook sultan Modafar van Ternate zich aansloot. (Vgl. Tiele, Europeërs, VII, bldz. 155-157; De Jonge, Opkomst, III, bldz. 104, 328-333.)

Een eewigh verbondt ende onverganckelijcke vriendtschap gemaekt tusschen den doorlughtige coninck van Ternate, kittchill ${ }^{3}$ Modofar, den gestrengen $\mathrm{h}^{\mathrm{r}}$ Symon Janszoon Hoen, viceadmirael van de 13 groote Nederlandsche schepen van wegen $\mathrm{d}^{\prime} E \mathrm{~d}^{\mathrm{le}} \mathrm{Mog}$. $\mathrm{H}^{\text {ren }}$ Staten der Geunieerde Nederlandsche Provintien, sijn princelijcke Ex ${ }^{\text {tie }}$, gebooren prince van Orange, grave van Nassouw, Cattsen Ellebooge, Vijanden, Marquis van der Veere, etc $^{\mathrm{a}}$, mitsg ${ }^{\text {ders }}$ de $\mathrm{H}^{\text {ren }}$ Bewinthebberen der Oost-Indische Comp $^{\text {e }}$ ter eenre, ende door requisitie van den groot maghtigen koninck, den koninck Landij ${ }^{4}$ vacalle $^{5}$ de

1 Vgl. hiervóór, bldz. 73, noot 2.

2 Uit het Contractboek.

s Kaïtjil = prins. - In de lezing van dit contract bij De Jonge bldz. 328) heet de bekende Modafar: "Modo Faro Suel" = Modafar Sultan?

“De Jonge heeft: „Coninck Louding".

5 Moet zijn: „van alle". (De Jonge, bldz. 328!. 
eijlanden, lieden en steden van Batcham ter andere zijde, den eenen den anderen beloovende op conincklijcke woorden dees naervolgende poincten ende artijculen in alle maniere naer ijder uijtterste vermogen naer te koomen.

Eerstelijck beloofft sijn konincklijcke May ${ }^{t}$ van Ternate ende met alle sijne gedeputeerde ${ }^{1}$ vrienden die de $\mathrm{Ed}^{\text {le }}$ Mogende $\mathrm{H}^{\text {ren }}$ Bewinthebberen ${ }^{2}$, sijn koninklijcke Maijt van Batchan tegen alle hosstyle proceduren onser vijanden te beschermen, die zijne $\mathrm{May}^{\mathrm{t}}$ voorschreven binnen sijne lemiten souden soeken eenige overlast offte affbreuke te doen, deselve soo veel mogelijck sall sijn te traineren ${ }^{3}$ ende sijne koninckrijcke van alle overlast te helpen defenderen.

Des beloofft sijn Konincklijcke May ${ }^{\mathrm{t}}$ van Batcham met alle zijne geallieerde, sijne Konincklijcke May ${ }^{t}$ van Ternaten ende sijne onderdanen tegen alle gewelt ende belegeringe onser vijanden met alle sijne maght resiproque te assisteren ende op het versoek dadelijek sonder eenigh vertreck ${ }^{4}$ te hulpe te komen.

Sullen ook alle de jnwoonders van de eijlanden van Caijo ende Geene ${ }^{5}$, die door de Konincklijcke May ${ }^{t}$ van Batchan voorschreven overwonnon sijn gowecst ${ }^{6}$ ende te vooren onder 't rijcke van Ternaten gestaen hebben, wederomme ondert voorschreven rijcke resorteren ende onder 't commandement van Sijne Konincklijcke Mayt van Ternata staen, sonder dat Sijne. Konincklijcke May ${ }^{\mathrm{t}}$ van Batchan daer eenige actie sall hebben te pretenderen.

Belangende het stuck van religie, sullen alle Sijns May ${ }^{\text {ts }}$ voorschreven ondersaten, soo van de Mooren ${ }^{7}$ als Heijdenen, haer gewillighlijken tot de Christen religie willende begeven ${ }^{8}$, vrijelijck mogen doen sonder dat Sijne Maijt offte de sijne 't selve in eeniger manieren soude mogen int openbaer offte heymelijck weeren ende sullen ook de gecommitteerde van de $\mathrm{H}^{\text {ren }}$ Bewinthebberen niet

1 De Jonge: "geallieerde".

${ }^{2}$ De Jonge: „de Ed. Mog. Heeren Staten-Genrl., sijn Princelijeke Extie, mitsgaders de heeren Bewinthebberen".

s De Jonge: "ruineren".

4 Vertrek $=$ uitstel.

${ }^{5}$ Kajoa. - Ganeh of Dowara. Of beteekent het: „degene"? (De Jonge, bldz. 328, v. is hier onduidelijk).

- Tiele, Europeërs, VII, bldz. 156.

7 De vorst zelf was Mohammedaan.

8 De Christen-propaganda der Spanjaarden en Portugeezen hadden op Batjan niet onbeteekenende resultaten gehad. (Vgl. Tiele, Europeërs, VII, bldz. 156.) 
vermogen, de mardijckers ${ }^{1}$ offte nieuwe Christenen, die door haer ernstigh versoek begeeren Moors te worden, int selve stuck te verhinderen, maer in sulcken gevalle veranderinge van religie moeten gedoogen.

Vorders belooven wij Symon Janszoon Hoen, van wegen d'Ed le Mogende $\mathrm{H}^{\text {ren }}$ Staten Gener, sijn Princel. Ex ${ }^{\text {tie }}$ ende de $\mathrm{H}^{\mathrm{ren}}$ Bewinthebberen voorschreven op Sijn Konincklijcke May ${ }^{\text {ts }}$ landt een cassteell te fortificeren, 't selve van soldaten, geschut, andere noodwendige ammonitie van oorlooge, naer ons vermogen van capitaell ende veell gedienstige manifacturen soo versien te houde, dat Sijn May ${ }^{\mathrm{t}}$ genoeghsaem van alle hostile proceduren der Spanjaerden mits Godts hulpe bevrijdt sall zijn.

In recompens vant voorschreven beloofft Zijne May ${ }^{\mathrm{t}}$ van Batchan, met alle sijne ondersaten de coopliede ende soldaten van de Nederlanderse natie met goede natie ${ }^{2}$ met goede plaetsen ende woningen, daer zij hare goederen, coopmanschappen ende waeren seguirlijcken mogen vertrouwen ende bequamlijck logieren, te versien, deselve nemende in sijne protectie ende bescherminge, sonder te lijden dat haer hinder offte leedt aengedaen werdt; maer te contrarie haer te patrocineeren sonder ${ }^{3}$ in stuck van haere negotie als andersints, daer zij Zijne Conincklijcke $\mathrm{May}^{\mathrm{t}}$ in van doen soude mogen hebben, sonder den cap ${ }^{t}$ vant fordt Barnevelt eenige van sijn volck offte correcorren, om den vijandt affbreuck te doen offte in eenige andere noodwendigen voorvallende saeken gelijck $\mathbf{4}$ te werden, te mogen weijgeren.

Nopende de handelinge der nagelen verbindt Sijne $\mathrm{May}^{\mathrm{t}}$ van Batchian, deselve aen geen andere natie als aen de gecommitteerde van de Generaele Vereeuighde Oostjndische Comp ${ }^{\mathbf{e}}$ te leveren en te vercopen, tot soodanigen prijs als de voorschreven gecommitteerde met Sijn Conincklijcke May ${ }^{\mathrm{t}}$ van Ternate bedongen hebben, zonder te leijden datse in eenige andere natie handen wegh gevoert worden.

Sullen ook geen swaerder tollen ende andere lasten, die op de negotie vallen, betalen als Sijne May ${ }^{\mathrm{t}}$ naturele jngebooren doen.

Aldus gedaen ter eere Godts, streckende tot augmentatie ende opservatie van de onderlinge jngegane vrindtschap tusschen beijde

1 Orang mardaheka of mardika $=$ vrij $\operatorname{man}$, iemand die vrij is van dienstbaarheid.

2 Deze overtollige woorden ontbreken bij De Jonge, bldz. 329.

s De Jonge: "soo".

"De Jonge: "gebruyet". 
des hooghgedaghtens Conincklijcke $\mathrm{May}^{\text {ts }}$ onderdanen ende onse voorschreven Nederlandsche natie ende tot ruijne [ende] distructie van de Portugesen en Spanjaerden neffens haere geassocieerde door de gestrenge $\mathrm{h}^{\text {re }}$ viceadmr ${ }^{1}$ Symon Janszoon Hoen, daertoe geauthoriseert van de Ed ${ }^{\text {e }}$ Mogende, $H^{\text {ren }}$ Staten Generl, sijn princelijcke $\mathrm{Ex}^{\text {tie }}$, etc ${ }^{\mathrm{a}}$, mitsgaders $\mathrm{d}^{\prime} \mathrm{H}^{\text {ren }}$ Bewinthebberen der Vereenighde Oosstindise Compe, blijkende bij de brieven van credentie, sijn Koonincklijcke May ${ }^{t}$ vertoont, beloovende deselve soo ras doenelijck zijn sall in amplissima forma te doen hebben.

Actum desen $10 \mathrm{X}^{\text {ber }} \mathrm{A}^{\circ}$ 1609. Op 't eijlandt Laboule ' ende was onderteijkent Sịmon Janszoon Hoen. ${ }^{2}$

\section{KUST VAN KOROMANDEL.}

29 Maart 1610. ${ }^{3}$

Arend Martenszoon had het kantoor van Tegenapatnam (zie hiervóór, blz. 55) „in goeden doen gebracht", * maar vond beter, eveneens een kantoor te vestigen te Tirepoplier, in de onmiddellijke nabijheid van Tegenapatnam. " Hiertoe werd dan ook onderstaand contract gesloten. Vgl. De Jonge, III, bldz. 339, v.)

Accoordt gemaeckt bij den cap $^{t}$ Arent Maertszn. ende Pieter Gerritszn. Bourgoingen van wegen ende uijt chracht van de $\mathrm{Ed}^{\text {le }}$ Mogende $\mathrm{H}^{\text {ren }}$ Staten ende sijne Princelijcke Ex ${ }^{\text {tie }}$ Mauritius de Nassau etc ${ }^{a}$ ter eener zijde ende Tiere Wingelaije, gouvern ${ }^{\mathrm{r}}$ over d'eijlanden ${ }^{6}$ Tindamandalam ter andere zijden, ende dat voor eeuwigh, gedaen adij den $29^{\mathrm{n}}$ Maart $\mathrm{A}^{\circ} 1610$.

1 De Jonge heeft hier juister: „Laboua in Batsjan", nl. Laboeha of Laboea aan de Westkust van het eiland.

" Bij de Jonge nog: „(Eenige Arabische karakters)".

$s$ Uit het Contractboek.

4 De Jonge, Opkomst, III, p. 339. Ten onrechte heeft hij er tusschen gevoegd: "(ons)". Hij had moeten lezen: "De plaetse van T. heeft (hij) oock", enz.

${ }^{5}$ Vgl. Valentijn, Koromandel, bldz. 9, 10 en de kaart.

- De Jonge, III, bldz. 345 heeft beter „die landen". De Gouverneur, waarvan hier sprake is, bestuurde deze streek namens den vorst (naïk) van Gingi. (Vgl. Baldaeus, Malabar-Choromandel, a, bldz. 157.) Over den naam Tindaof Tonda-Mandalam, vgl. Hobson-Jobson, p. 199, sub voce "Coromandel". (Mandalam = landstreek, koninkrijk). - Baldaeus noemt deze gouverneur: "Trinvingelaya, doorgaens den Grooten Aya genaemt". (Bldz. 158.) Aya is blijkbaar de titel van dezen stadhouder. Ayya is in vele Indische volkstalen een verbastering van het Sanskrit Ârya $=$ heer. 
Eerstelijck sall sijn Princel. Ex ${ }^{\text {tie }}$ hebben binnen de fortresse van Tïerepopelier het huijs, genaemt Nota Calamatta Coin, ${ }^{1}$ dat int voorschreven fort staet, gemaekt van blauwen arduijn steen, lanck zijnde hondert en vijff voeten, breed vier en t' seventigh voeten ende heefft hooghte naer advenandt, welcke op heden ons ${ }^{2}$ Prince voor sijne ondersaten is geschoncken ende overgelevert, sonder daer yets voor te betalen, omme alle ammonitie van oorloogen, cruijt, loot, kogels, londt, anckers, touwen, seijlen en soo alle andere coopmanschappen te mogen bewaren voor brandt, roovers, dieven ende meer ongelucken; dewelcke plaatse wij Hollanders, Zeelanders, die van wegen de Generaele Comp. zijn, zullen vermogen te timmeren naer ons gelieven, mits dat wij sullen gehouden wesen aau landt te brengen binnen voorschreven fortresse een metale halve france ${ }^{3}$ cartouw ende drije ijsere grotelingen ${ }^{4}$ tot bescherminge van ons ende de $\mathrm{H}^{\text {ren }}$ Bewinthebberen goederen, dewelcken plaetse Aije ${ }^{5}$ sall gehouden zijn ons te helpen bewaren ende assisteren tegens de Portugesen ende alle andere die ons eenige schaden offte affbreuck souden willen doen, hetwelcken den voorschreven aije tot zijne kossten zall moeten onderhouden.

Ook sullen wij, die van de Generale Vereenighde Oosstindische Comp. sijn, gehouden wesen te betalen van alle goederen ende coopmanschappen die hier gelosst ende geladen sullen worden 2 ten 100 , well verstaende $t^{\prime}$ geene dat eens betaelt heefft niet meer en sall betalen; ook geldt, rijs en andere behoefftigheden voor de forte en ${ }^{6}$ sullen niet betaelen.

Den Aije en zall niet vermogen, eenige Portugesen te laten woonen offte handelen in Tegenepatam offte in de plaetse van Tijrapoupelier, maer vijandt daer van te blijven.

Niemandt van beijde zijde sall vermogen, eenige questie, arguatie offte disputatie van de religie maeken.

Soo daer ijmandt hem begave door eenige quadt feijt over te loopen beij den Aije offte in zijn landt, soo sall den Aija gehouden wesen, deselve over te leveren in handen van d'onse.

1 De Jonge, III, bldz. 345: „Nocte Callalamatte.” Vgl. Baldaeus, bldz. 157.

2 Nl. van de Nederlanders.

$s$ Dit woord niet bij De Tonge. - Een kartouw is een verouderde benaming voor een zeker soort kanonnen. Vgl. Baldaeus, t. a. p., blz. 157.

"De Jonge: "gootlingen". Goteling is een soort licht scheepsgeschut.

5 De Jonge, bldz. 346, heeft: „de Aya", nl. de gouverneur, van wien in den aanhef sprake is.

"De Jonge heeft: "voor die fortresse en 't huys". 
Voordt sullen alle persoonen coopluyden vermogen met ons te handelen, kopen, verkopen alle coopmanschappen, ende goederen behalven de zuawall, ${ }^{1}$ het welck aen de Naijck ${ }^{2}$ offte Aija eerst gepresenteert zall worden om aen hem te verkopen.

Alle schilders ende wevers, die eenige obligatie met ons maken van wegen eenige kleeden te laten schilderen offte doeken te leveren, zullen gehouden wesen het selffde naer te komen ende bij faullte van dien sall den Capiteijn, die hier is blijvende, vermogen deselve aen te tassten ende alhier in de boeijen te sluijten, waerover den Aija zall gehouden wesen, corte expeditie ${ }^{3}$ te doen ende het selffde naer laten komen, all soo het dan geaccordeert zall wesen.

Ook en sall den Aija niet vermogen hier te laten handelen eenige Europische natien dan die bescheijdt van zijne Princelijcke Ex ${ }^{\text {tie }}$ brengen.

Wij sullen oock vermogen te handelen in Porto Novo ${ }^{4}$, daer wij oock mogen lossen ende laden naer ons believen.

Ook soo belooven wij van wegen de Generale Compe aen den Aija, soo hij eenige goederen, geschutt, ammonitie van oorlooge offte andere fraijigheden uijt onse lande begeert te ontbieden, soo sullen wij dezelve gehouden wesen hier met de eerste gelegentheijt te brengen, voor deselve den Aija sall betaelen, gelijck het zall in ons landt gekosst hebben.

Oock en sullen wij niet vermogen, soo wanneer wij op de rheede van Tegenepatnam offte Porto Novo met onse scheepen ten ancker liggen, eenige schepen schade te doen offte aenhalen.

Alle de schepen, die van hier naer andere plaetsen sullen seijlen met passpoordt van onse capiteijn, en sullen onse Hollanders, Zeelanders, offte die van de Generale Compagnie eenige schade te doen. 5

Soo den Aija een passpoordt van de $\mathrm{Cap}^{\mathrm{n}}$ begeerdt om eenige goederen van eenige plaetsen te ontbieden voor sijn particulier ende niet meer, sullen gehouden wesen te geven.

Alle welcke voorschreven contract ick Aija Tiera Wingel Aija, gouvern $^{r}$ van den voorschreven landen, beloove nu nogh nimmermeer te breken; dat zweerde ick op op mijnen naijk Chrisstoppen

1 De Jonge: „swavel".

2 De naik (nayak) van Gingi. (Vgl. Hobson-Jobson, p. 470, sub voce "Naik").

s De Junge: „corte executie".

- Ten Zuiden van Pondicherri.

"De Jonge, bldz. 347: "niet vermoogen eenige schade te doen". 
Aija. ${ }^{1}$ Wij contractanten ter andere zijde belooven oock uijt den naemen van de Generale Comp. t' selve zij sweerende op onsen Prince, ${ }^{2}$ nu nogh nimmer meer niet te breken. Ende was besegelt met sijn singenet ${ }^{3}$ en onderteekent Arent Maertenszoon, PreGerritszoon Bourgonge.

\section{CEILON.}

13 April 1610. 4

Onze eerste aanrakingen met Ceilon dagteekenen van 't midden van 1602 , op den bekenden tocht van Joris van Spilbergh of Van Spilbergen. (Vgl. De Jonge, III, bldz. 3-14; Van Geer, Ceilon, bldz. 11-21), later gevolgd door slecht afgeloopen bezoeken van Sebald de Weert (namens de Oost-Indische Compagnie van 1602) in dit jaar en in 1603. De Bewindhebbers verloren het belang, hetwelk dit op de handelsroute van Oost naar West zoo gunstig gelegen eiland, dat buitendien de winstbelovende kaneel opleverde, voor ons kon hebben, in de eerstvolgende jaren echter niet uit het oog. En gaarne - te liever nog met het oog op de onderhandelingen in Europa omtrent en de sluiting dáár van het Twaalfjarig Bestand - ging men in op een nadere verhouding, toen de beheerscher van Ceilon zelf daartoe aanleiding (in 1610) gaf. (Vgl. De Jonge, Opkomst, III, bldz. 137, 350, noot 1; Van Geer, bldz. 21-23).

Accoort gemaeckt door Carolus de Lannoye, gecommitteert van capt. Willem Jansz., ${ }^{5}$ uytt cracht vau Syne Princelycke Ex ${ }^{\text {te }}$ Mauritius, prince van Orangien, grave Nassau, enz. enz. enz., Admirael, CapteynGenerael van de zee, ter eenre: en den Doorluchtigen Hoochgeboren Kayser van Ceylon, Coninck van Candy, genaempt Seneratadazyn, ${ }^{6}$ ten andre; gedaen den 13 April 1610.

1 Valentijn, t. a. p., bldz. 10, noemt den vorst van Gingi: „den Naik, of Graave des Lands, Christapaneyk genoemd." Vgl. Baldaeus, t. a. p., bldz. 160. - Hobson-Jobson, p. 470. - De Jonge, bldz. 347, spelt in "Mijnen Nayk" het eerste woord vermoedelijk foutief met een hoofdletter.

2 De Jonge, bldz. 347, heeft, iets duidelijker: „tselve naer te comen, en tselve sijn swerende op onsen prince, enz.

3 De Jonge: "Onderstont in roode was gedruckt het zegel van den Aya en daerbij geschreven: dit is die bevestinge van den Aya: Tierewingelaya".

4 Overgenomen uit De Jonge, Opkomst, III, bldz. 350, v.

5 Op de Eendracht.

- Ceilon was verdeeld in eenige staten, leenrijken van het rijk Kandy. De radja's van die rijkjes waren vazallen van Kandy's maharadja, Ceilons oppervorst. Seneratadaryn is blijkbaar een onnauwkeurige spelling. (Baldaeus, Malabar-Ceilon, b, bldz. 22, enz., noemt hem Cenuwieraat Adascijn). 7• Volgr. III. 
1. In den eersten alsoo noodich is, dat Zyne Princelycke Excellentie voor syne ondersaten, tot bevoirderinghe van de negotie van deselve in Oost-Indien, eenige plaetse van doen heeft, om syne goederen, coopmanschappen en andersints te bewaeren, ${ }^{1}$ sal Syne May ${ }^{t}$ aan Syne Princel. Ex ${ }^{\text {tie }}$ ofte synen eaptain geven alsulcken plaets in Candy, als sy sullen begeren, soo groot ofte cleen, als Syn Excel ${ }^{\text {tie }}$ ofte synen capteyn sal goetduncken.

2. Sal Syn May ${ }^{t}$ oock verbonden wezen, die goederen, die Syne Princl. Ex $x^{\text {ties }}$ ondersaten in Syn May land te vercoopen brengen, sonder haere costen in Candy te beschicken, en weder haere goederen die sullen incoopen, sonder haere oncosten aen die schepen te leveren, dus sullen Syne Excellenties schepen ten ancker en op die reede comen van de plaetsen Tyrekonnemale ${ }^{2}$ en Cottiaer. ${ }^{3}$

3. Sullen oock alle vassallen van Syne Princelycke Ex ${ }^{\text {tie }}$, syne schepen en goederen, van wat plaetse datse comen, wederom versonden worden mogen, sonder dat Zyne May ${ }^{t}$ yets op sal te seggen hebben, noch eenige tol aff genieten.

4. Sal Syne Princelycke Ex ${ }^{\text {tie }}$ oock vermogen in der May ${ }^{\text {ts }}$ landen hout te halen en te houwen tot bouwinge van de schepen.

5. Sal Syne May ${ }^{t}$ oock niet vermogen eenige beswaringen ofte tollen te nemen van de schepen, bescheyt van Zyne Princel. Ex tie hebbende, tsy van goederen, die sy sullen laden offte ontladen.

6. Soo eenige persoonen van d'een offte ander partyen yet op den anderen hebben te seggen van schult en weerschult, tzy door leenen offte coopmanschappen, hoe het soude moogen wesen geschiet, sal Syne May ${ }^{t}$ gehouden syn ten eersten versouck van den aenclager recht te doen.

7. Sooder yemant van de onsen om quaet regiment by Syne May ${ }^{t}$ hulpe versocht, tsy met loochenen van syn gelove offte andersints, om syn quaet leven te bedecken, sal Syn May ${ }^{t}$ haer niet aenhouden; maer geven hem in bewaringhe van die onsen, om ter gelegener tyd sulcke straffe over te doen, datter een ander een exempel aan sal nemen.

8. Oock en sal Syne May ${ }^{t}$ niet vermogen, die Poortugesen offte

1 Het in de eerste jaren der $17^{\text {de }}$ eeuw telkens meer opkomende denkbeeld van een centrum voor de O. I. C. in het Oosten, een z.g. rendez-vous.

2 Trincomalee (Trinkomale), aan de Westkust van het eiland. De havenplaatsen van Ceilon waren overigens meest in handen der Portugeezen. (Zie Van Geer, bldz. 8).

3 Thans Koddiyarap, evenals Trincomalee gelegen aan de Baai van Koddiyarap. (Vgl. Valentijns kaart van Ceilon en Valentijn V, 1, b (Ceilon) bldz. 32.) 
Castelianen eenigen handel te verleenen: dus sal Syn Princel. Ex ${ }^{i \theta}$ met Syne May ${ }^{t}$ geduirige vrientschap onderhouden en an Zijne May ${ }^{\mathrm{t}}$ vyanden, die Coninck van Spangien en Poortugael ', geen assistentie vermogen te doen tzy met volck, geschutt, schepen offte ammonitie van oorloge.

9. Syne $\mathrm{May}^{\mathrm{t}}$ eenige goederen wtt onse landen van doen hebbende, hoe die souden moogen wesen, sullen [wij] dieselve brengen, mits Syne May ${ }^{t}$ ons daer gelt offte waeren voor sal geven, voor soovele als Syne May ${ }^{t}$ met ons can accordeeren.

10. Soo wie eenige schandael in eenige saecken van religie geeft, die sal aengeclaecht en gestrafft worden, by syne overheyt daer hy onder sorteert, soowel van d'eene als d'ander zyde.

\section{KUST VAN KOROMANDEL.}

\section{April $1610{ }^{2}$.}

Volgens een missive van Jaeques l'Hermite te Bantam aan de Bewindhebbers der O. I. C. van den 10 November 1610 was ${ }^{\mathrm{S}}$. Arent Maertsen selffs bij den Coninck van Gingier geweest ende (had hij) plaetse van Paleacatta vercreghen om een huijs te maecken ende daer vryelyck te moghen handelen, twelck gheen cleyne saecke is, aengesien wel een van de bequaemste plaetsen is van de geheele custe ende men daer alle sorteringhe van cleeden à contentement sal connen becomen." (De Jonge, opkomst, III, bldz. 339.) $\mathrm{Nu}$ is in het onderstaand contract echter geen sprake van den "Coninck van Gingier", maar van dien van „Carnatica", enz. L'Hermite vergist zich, want met den vorst van Gingi en dien van "Carnatica" kan niet één en denzelfde persoon zijn bedoeld. Met Carnatica (Kanara) wordt hier bedoeld het overblijfsel van het Hindoe-rijk Vijáyanagar na den noodlottigen slag bij Talikot of Telicotta in 1565. De radja's van dat rijk vestigden zich toen in het tegenwoordige North Arcot district (zie de kaart 11 in Hunter's atlas). Hun rijk staat ook bekend onder den naam Chandragiri of Vellore. ${ }^{3}$ Wel was Gingi een onderhoorigheid van Vijáyanagar of Carnatica (vgl. hiervóór, bldz. 55, noot 3), maar Pulicat lag niet in Gingi.

1 Zooals bekend is, hadden de Portugeezen verschillende van de belangrijkste havenplaatsen van Ceilon in bezit, en konden daardoor den kaneelhandel bijna dwingen. De O. I. C. en de maharadja van Kandy hadden hier dus gemeenschappelijke belangen, althans voor het oogenblik.

2 Uit het Contractboek. De Jonge, Opkomst, IU, bldz. 348, v. heeft eene andere lezing.

3 Vgl. Gribble, Deccan, I, p. 195. - Hunter, Gazetteer, V, p. 196, 266, II, 396, IX, 231; IV, 335, 336, v. - Hobson-Jobson, p. 125. - Baldaeus, Malabar-Choromandel, a, bldz. 160 en de kaart van Koromandel bij Valentijn (V. 1). - W. Foster, The founding of Fort St. George, Madras (Londen, Eyre and Spottiswoode, 1902), p. 1, f. 
Accoordt gemaeckt bij den capiteijn Arent Maertszoon van wegen ende uijt chraghte van de $E d^{\text {le }}$ Mogende $\mathrm{H}^{\text {ren }}$ Staten Gener ${ }^{1}$ ende Sijn princelijcke Ex ${ }^{\text {tie }}$ Mauritius de Nassouw ter eenre ende den doorlughtigen hooghgebooren koninck genaemt Vinka Wepatijraijer Alou Patij 1, koninck over de eijlanden Cenatica, Sinwassena, Paty ${ }^{2}$ ende meer andere heerlickheden ten andere zijde; ende dat voor eeuwigh; den $24^{\mathrm{e}}$ Aprill $\mathrm{A}^{\circ} 1610$.

Eertelijck sal Sijne Princelijcke Ex ${ }^{\text {tie }}$ voor zijne ondersaten hebben in Palliacatta ${ }^{3}$ een plaetse om te timmeren eenen steenen huijs, om alle ammonitie van oorloogen, kruijdt, loodt, kogels, londt, anckers, kabels, touwen, zeijlen ende alle andere coopmanschappen te mogen bewaren voor brandt, roovers, dieven en meer andere ongelucken.

Vuorts sullen wij, Hollanders, Zeelanders endéalle die van wegen de Generale Comp ${ }^{e}$ hier traffiqueren, gehouden wesen te betalen van alle goederen en coopmanschappen [die] hier gelost en geladen sullen worden, 2 ten 100 , well verstaende, t'geene dat eeus betaelt heefft, niet meer en sall betaelen; oock gelt, rijs en andere behoefften voor het huijs en sall oock niet betaelen.

Den Koninck en sal niet vermogen, eenige Portugesen te laten wonen offte handelen in Palleacatta, maer ter contrarie haer 't selve te verbieden.

Niemandt en sal vermogen, aen beyde zijde eenige quaesstie, arguatie offte disputatie van de religie te maeken.

Soo daer ijmandt hem begave door eenigh quadt feijt over te loopen bij den Koninck off int landt, soo sall den Koningh gehouden wesen deselve over te leveren.

Voorts sullen alle persoonen ende coopluijden met ons vermogen te handelen, kopen, verkoopen alle coopmanschappen ende goederen, zonder dat ijmandt sulcx soude mogen verbieden.

Alle schillders ende wevers, die eenige obligatie alhier met onse natie sullen maeken van wegen eenige kleeden te schilderen offte doeken te leveren, sullen gehouden wesen, t'selve naer te komen ende bij faulte. van dien sal den $\mathrm{Cap}^{\mathrm{n}}$, die alhier is blijvende, vermogen aen te tassten en in de boeijen te stellen, waer over den

1 De Jonge, III, blz. 348 heeft: "Vinkata Pati Raya Alou".

2 Chittivalasa en Pattikonda?? De Jonge heeft beter: „die landen Carnatica" enz.

3 Thans Pulicat, ten Noorden van Madras. 
Koninck zall gehouden - wesen, corte expeditie ${ }^{1}$ te laten doen ende haer het selve alles naer te laten komen, soo het dan geaccordeert zall wesen.

Oock en sall den Koninck niet vermogen, hier te laten handelen eenige Europische natie dan alleen die bescheijt van Zijn Princelijcke Ex ${ }^{\text {tie }}$ brengen.

Oock soo belooven wij van wegen de Generale Comp als den Koninck eenige goederen, geschut, ammonitie van oorlogen offte andere fraijigheden uyt onse landen begeeren te ontbieden, soo sullen wij gehouden wesen deselve met d'eerste gelegentheijt hier te brengen, voor hetwelcke den Koninck sall gehouden wesen te betalen gelijck het in ons landt gecosst heefft.

Soo wanneer wij op de rheede van Palliacatta leggen ten ancker, zoo sullen wij niet vermogen eenige ${ }^{2}$ schade te doen offte aen te haelen.

Alle schepen die van hier naer andere plaetsen sullen zeijlen met paspoort van onsen capiteijn, en sullen onse natie niet vermogen eenige schade te doen.

Alle welcke voorschreven contract jck, Vinka Tapatij Raija Alou, koninck over de landen Carnatica, Simwater ${ }^{3}$, Patij ende meer andere heerlijckheden, beloove nu nogh nimmer meer te breken, het welck ick sweeren bij mijnen Godt Serumall *. Ick, contractant van wegen de Generale Oosstindische Compe ${ }^{\mathrm{e}}$, beloove mede t'selve nu nogh nimmermeer niet te breken. Soo waerlijck moet mijn Godt helpen. Was geteijkent bij des Konincx handt. Onderstondt Arent Maertszoon. ${ }^{5}$

\section{DJAKATRA.}

\section{Januari 1611. ${ }^{6}$}

Verschillende omstandigheden (o. a. de onrustige toestanden en de ongezondheid van Bantam) hadden reeds sedert 1607 de aandacht der Neder-

1 De Jonge, bldz. 349, heeft: "corte executie".

2 Bij de Jonge: „eenige schepen schade te doen”, enz.

s De Jonge: "Sinwakena".

"De Jonge: "Perumal". Wat dit beteekent? Perumal is de naam van een vorst, die een groot deel der kust van Malabar eens beheerschte. Kan de aanroeping Perumal hiermede in verband staan?? (Hunter, Gazetteer, VI, p. 244).

5 Bij De Jonge luidt het slot: „Onderstondt in swarten lack gedrukt het segel van den Cooninck en daerbij stont geschreven: dit is het segel van den Cooninck, bij Zijne Majesteyt zelffs gedruckt; tot meerder versekeringhe heeft (dé Koning) ons noch sijn handt gedruckt op eenen doeck gegeven, dat men noempt de hand van Sandel, en onderteeckent Arent Maertss".

${ }^{6}$ Uit het Contractboek. Het is daar verkeerd geplaatst tusschen contracten 
landsche autoriteiten doen vestigen op Djakatra als geschikt voor een algemeen „rendez-vous" voor de Nederlandsche schepen in Indië. Vooral Cornelis Matelieff de jonge wees op het belang dezer plaats; nog meer Jacques l'Hermite, hoofd van het "generaal kantoor" te Bantam, die in November 1610 een contract met den bestuurder van Djakatra sloot. De datum is niet stellig bekend, maar moet ongeveer 13 November 1610 zijn, niet later, vermoedelijk niet veel vroeger. (Vgl. De Jonge, Opkomst, III. bldz. 138 v., 344, v; 352-354; Tiele, Europeërs, VII, bldz. 122, 170 v.; Van der Chijs, Jakatra, bldz. 6-7, 197-203). Maar toen de GG. Pieter Both in Januari 1611 in Djakatra kwam, werd het contract eenigermate gewijzigd. Het is dit gewijzigde contract. dat tot ons is gekomen. (De Jong, Opkomst, IV, bldz. IV).

Accoordt ende contract gemaeckt bij den capt $^{\mathrm{n}}$. $\mathrm{Jacq}^{\mathrm{s}}$ Lhermite de jonge uijt den name ende van wegen d'Ed ${ }^{\text {le }}$ Mogende Heeren Staten Gener' der Vereenighde Nederlandsche provintien ende Sijne Exc ${ }^{\mathrm{ie}}$ Mauritius

- de Nassouw etc ${ }^{a}$, ter eenre ende den doorlughtigen Widiach Rama ${ }^{1}$, coninck van Jacatra ter andere zijde ende dat voor eeuwigh; desen

anno $^{2}$

Eerstelijck sall den koninck voorschreven aen de ondersaten van de $\mathrm{H}^{\text {ren }}$ Staten voorschreven, behoorlijcke commissie hebbende, in Jacatra verleenen vrije handelinge en suffisante woonplaetsen, daer haere personen ende goederen in goeder bewaringe mogen zijn, om dewelcke te bouwen ous sall verleenen een plaetse, geleegen in het Chinees quartier, groot vijfftigh vadem in de lenghte ende soo veell in de breedte offte grooter, in dien sulcx van noode hadden, voor welcke voorschreven plaetse sullen betalen aen den Koninck $1200 \mathrm{R}^{\mathrm{a}}$ van aghten, waerop ons sall laten timmeren naer ons gelieven ende steenen huijse ${ }^{3}$ laten bouwen, soo groot ende cleyn, als ons sall te passe komen, welcke huijsen, persoonen ende goederen hij oock sall gehouden wesen te helpen beschermen tegen alle aenvall van vyanden wie die oock souden mogen wesen.

Hiertegens sullen de voordaghte Hoge Mogende $\mathrm{H}^{\text {ren }}$ Staten Gene-

van 12 December 1612 en Januari 1613. Van der Chijs, Jakatra, bldz. 196-200, heeft hetzelfde contract overgenomen "volgens een oud afschrift op de algemeene secretarie te Batavia berustende."

1 Aan het slot wordt deze naam gespeld: "Wizia Garama"; moet vermoedelijk zijnn: Widjåjå Kråmå. De zg. "Coninck" was een vazal van Bantam. Elders (zie hierna contract 21 Dec. 1614) draagt hij den titel Pangeran.

2 Niet ingevuld. Moet vermoedelijk zijn November 1610 , omdat het hier geldt den datum waarop l'Hermite het eerste contract heeft gesloten.

s Van der Chijs, bldz. 197, heeft hier "huysen." 
rael der Vereenigde Nederlanden gehouden zijn, den voorschreven coninck van Jacatra zijne onderdanen ende landen te helpen beschermen ende assisteeren tegen alle geweldt ende jnvasie te water ende te lande, die hem door Spangiaerden, Portugesen offte eenige andere vijanden zoude mogen aengedaen worden directelijck offte indirectelijck.

Maer indien den Koninck buijten sijn landt eenige oorlooge offte interprince aenveerde, sullen de voorschreven Hollanders hem niet gehouden zijn te assisteren nogh eenigh behulp te doen te water offte lande.

Ende opdat naermaells op 't stuck van den handell offte coopmanschappe geen differentie en valle, dat ' ${ }^{1}$ door vervreemdinge van partijen soude mogen ontstaen, sijn met malcanderen overeengecomen ende geaccordeert als volgt:

Eerstelijck sall den koninck voorschreven genieten voor toll van den peper, die alldaer soude mogen kopen ende laden 5 ten 100 , denselven taxerende gelijckse kost ende van bilibilian ende robbe robbe van den selven peper sall genieten $10 \mathrm{Ra}$ van 8ten van elcke 100 sakken. Den Sabander zall genieten voor robbe robbe van elcke 100 sacken $2 \mathrm{Ra}$ van 8 ten, van gelijcken de schrijvers van elcke 100 zacken $2 \mathrm{Ra}$ ende den weger van elcke 100 zacken eenen Ra.

Van alle andere waren als sandelhout, noten, macis ${ }^{2}$, nagelen en andere diergelijcke coopmanschappen, die de voorschreven Hollanders in Jacatra souden mogen kopen ende in hare schepen laden, sullen gehouden sijn te betalen aen den voorschreven koninck 5 p $^{\mathrm{r}}$ sento en niet meer.

Wel verstaende dat hier inne niet en sullen begrepen sijn eenige Chineesche waren als zijde, zijde wercken, porceleijn ende andere diergelijcke, maer sullen deselve sonder eenige belastinge vrij mogen kopen ende uijtvoeren.

Sullen de voorschreven Hollanders, Zeelanders, etca alle waren, hoedanigh die souden mogen wesen, die met hare schepen, jaghten, joncken offte andersints brengen, hier vermogen te lossen ende wederomme naer hun believen te laden ende uijtvoeren offte verkopen, zonder deselve eenighsints met eenige tollen offte eenige andere beswarenisse te belasten.

1 Moet gelezen worden: „daer."

2 De Latijnsche naam voor foelie. 
Sullen oock vermogen, op alle des Koninghs landen ende eijlanden hier omtrent hout te houwen ende te laten houwen tot bouwinge van schepen ende andersints daer 't selve souden mogen van doen hebben, sonder belet offte molestatie.

Ende offt geviele datter ijmandt van 't volck van de Hollanders, tzij witte, offte swarte, om eenigh moetwilligh feijt offte misdaet weghliep, sall den koninck voorschreven gehouden zijn, wederom. te leveren, om deselve naer merite te mogen straffen, d'welck ook de voorschreven Hollanders sullen gehouden wesen te doen, jngevalle ijmandt van des Koninghs volcks bij voorschreven Holland ${ }^{\text {rs }}$ vlughted ${ }^{\text {en }}$.

Ende op datter [door] maninge van schulden geen differentie en valle, sullen de voorschreven Hollanders, eenige goederen aen Chineesen off Javanen verkopende, op dagh ${ }^{1}$ dat het selve geschiede met voorwetten van den Sabander, op datter geen quade schulden gemaeckt en worden; ende jngevalle eenige onder de handt quadt. worden, den voorschreven koninck ${ }^{2}$ aen onse betalinge magh helpen.

Jngevalle ook ymandt ware, t'zij Javanen, Chineesen offte andere natie, die de Hollanders in eenige dingen verongelijcken, sal den Koninck gehouden zijn ons aen ons reght te helpen ende de misdadige straffen ende jngevalle ymandt van de Hollanders eenige overlast aen Javanen offt ymandt anders deden, sullen deselve van gelycken dadelycken geapprehendeert worden en naer haere merite gestrafft.

Sall den Koninck ook niet vermogen, eenige Portugesen offt Spangiaerden toe te laten in zijn landt [tot] eenige handelinge, maer deselve geheelyck daer uijt weeren.

Alle welcke bovengeschreven artykelen wij ondergeschreven bekennen met mallcanderen gecontracteert te hebben ende belooven van weder zijden, die nu en ten eeuwigen dage onverbrekelyck te onderhouden. Jn kennisse der waerheijt dit met ons gewoonlijcke handteeken onderteekendt in Jacatra datum utsupra. Onder stont: affirmere 't gunt voorschreven. Was geteeckent Pieter Both ${ }^{3}$.

1 Van der Chijs, bldz. 200: sorg dragen."

2 Van der Chijs: „ons aen," enz.

$s$ Deze bevestiging van het contract door Both moet hebben plaats gehad in Januari 1611. 
Bovenstaand contract was blijkbaar opgemaakt in het Nederlandsch en in het Maleisch. Van den Maleischen tekst heeft de bekende Herbert de Jager' een vermoedelijk verkorte vertaling gemaakt, die ik hier opneem, omdat zij enkele verschillen met den Nederlandschen tekst vertoont. Deze lezing van het contract is opgenomen bij De Jonge, bldz. 352-354. Waarom de hierboveristaande niet, is niet duidelijk. Van der Chijs, bldz. 197-203, nam ze beiden op. Nu zegt De Jonge, bldz 352, noot 1, dat Van der Chijs, die het contract stelt op 28 Januari 1611, in dwaling is, en dat de datum moet zijn 10-13 November 1610. Neen! De Jonge zag dit contract aan voor het oorspronkelijk contract van l'Hermite, terwijl dit het contract is, zooals Both het zelf heeft bevestigd in Djakatra. Het blijkt uit wat hij zelf zegt op bldz IV van deel IV, want de vrijdom van tol voor levensmiddelen komt in het contract niet voor. Vgl. nog Valentijn, IV (Java), bldz. 434-436. en L. C. D. van Dijk, Wemmer van Berchem, bldz 10, v, noot 3.)

Translaet uijt het Maleytsch van het voorschreven contract nu ${ }^{2}$ bij den onderkoopman Herbert de Jager overgeset.

Ditt is het contract van den koninck van Ziakarata met den capiteijn Jaques l'Hermite de jonge, affgesondene van Mauritts de Nassouw, prins van Orangie, en de Staten van Hollandt ${ }^{3}$ jngegaen.

De Hollanders die tot de ${ }^{4}$ Ziacarata gekomen zijn ende een missive van Mauritts de Nassouw en de Staten van Hollandt medegebraght hebben, deselve staet den koninch van Ziacarata ${ }^{5}$ en daer beneffens een goede plaets om een logie te stighten om hare

1 Zie over hem P. A. Leupe in deze Bijdragen, Nieuwe Volgreeks, IV, bldz. 17 v.v.; $3^{\circ}$ Volgreeks, IV, bldz. 67 vv.

2 Misschien tusschen 1663 en 1665, toen De Jager ambtenaar was ter secretarie van de Hooge Regeering te Batavia. Ook tusschen 1680 en 1683 echter en tusschen 1687 en 1694 heeft De Jager te Batavia vertoefd en het zou ook kunnen zijn, dat hij de vertalingen heeft gemaakt voor den oudgouverneur-generaal Camphuys ten behoeve van diens bekende memorie over Djakatra. (Valentijn, IV, bldz. 419 vv.) In zijn tekst heeft Camphuys dan echter De Jager's vertalingen niet opgenomen. Trouwens De Jager was in die jaren geen onderkoopman meer.

3 Van der Chijs, bldz. 201, noot 2, zegt dat het "opmerking verdient, dat in het Maleische stuk de naam van Prins Maurits vóór dien der Staten wordt genoemd." Ik vermoed, dat men hier heeft te doen met de gewone wijze van handelen der vertegenwoordigers van de O. I. C. in het Oosten, dat zij nl., als het zoo te pas kwam, den Prins van Oranje op den voorgrond plaatsen. Een vorst aan 't hoofd maakte h.i. beteren indruk, werd beter begrepen in het Oosten dan zoo iets als Staten-Generaal of Staten van Holland.

"De Jonge, bldz. 352, heeft: „de stadt" enz.

5 De Jonge: "toe te handelen in de stadt van Zjacarata," enz. 
coopmanschappen te bergen, hebbende in de lenghte $\mathbf{5 0}$ vademen lenghte en ook soo veell in de breete, allwaer een logie sullen timmeren t'zij groot off kleijn, soo als zij sullen goedt vinden, mits de Hollanders daer voor aen den koninck van Siacarata sullen betalen twaelff hondert Ra. En soo de Hollanders van ymandt eenige molestie aengedaen werden, $\mathrm{t}$ zij ook wie het soude mogen wesen, soo sall den koninch van Siajacarata de Hollanders hier in zijne hulpe bieden.

Indien ijmandt eenigh quadt tegen den stadt van Zyacarata bedrijve, t'zij Castilijanen off Portugesen off ymandt anders, en dat deselve jut landt van den koninck van Ziajacarata eenigh geweldt aenreghten, soo sullen de Hollanders, die in Ziajacarata zijn, t'samen met hare schepen den koninck van Ziajakarata assistentie bewijsen.

Indien de koninck van Ziajacarata eenigh landt beoorlooght, t'zij te lande off te water, soo sullen de Hollanderen met hem niet gaen.

En omdat wegen de negotie geen questie en valle, zoo hebben wij met den koninck van Siajacarata geaccordeert, dat zoo wanneer de Hollanders peper laden, dewelcke in de stadt van Ziajacarata gekogt hebben, zoo sullen se voor toll betalen van ijder 100 gewigten 5: gewichten ende dat voo̊r den koninck van Ziajacatara, en sall desen toll altijt gereguleert worden nae dat de' prijs der selven dier offte goede koop is. Voorts den toll van billij bilibian met de roeba roeba voor de Koninck, sall bedragen tien $\mathrm{R}^{\mathrm{a}}$ voor 100 gewichten. En wat aengaet de roeba roeba voor den Sabander, deselve sall voor 100 gewighten $2 \mathrm{R}^{\mathrm{a}}$ bedraghen, gelijck mede voor de schrijvers twee $\mathrm{R}^{\mathrm{a}}$ voor de honderdt gewichten ende voor de waghmeester ${ }^{1}$ een $\mathrm{R}^{\mathrm{a}}$ voor 100 gewighten.

Soo de Hollanderen eenige koopmanschappen kopen, als sandelhoudt, note muscaten, foeylie, nagelen en diergelijcke waren, soo se deselve laden, soo sullen se aen den Koninck voor toll betalen voor $100 \mathrm{R}^{\mathrm{a}} 5 \mathrm{R}^{\mathrm{a}}$, niet meer nogh minder.

Soo de Hollanders eenige Chineesche waren kopen, gelijk tafftazijde $^{2}$ stoffen off diergelijcke saken, en sullen daer gantsch geen toll aff betalen; soo se willen laden in een schip, soo laden se maer en soo se die willen verkopen aen t'landt, soo verkoopen se maer aen landt, soo als 't haer sal believen.

Soo de Hollanderen eenige coopmanschappen in een schip off jonck tot Siajacarata aenbrengen, deselve sullen se daer mogen

1 Van der Chijs, bldz. 202: "Waegmeester."

2 Ons "taf" (lichte, geheel uit gekookte zijde geweven effen stof.") 
ontladen sonder daer eenige toll van te betalen, maer deselve nae haer believen mogen verkopen en soo se niet van sints moghten sijn deselve alldaer te verkopen, soo sullen se deselve weder mogen laden, soo als se sullen goedt vinden.

De Hollanders, die in de stadt van Ziajacarata resideren, en sall den Koninck niet beletten aen d'eylanden houdt te haelen om haere schepen etc ${ }^{\mathrm{a}}$. te bouwen.

Soo een slaeff van de Hollanderen yets tegen de Hollanderen misdoe en kome wegh te loopen tot den $\mathrm{Ko}^{\mathrm{k}}$, deselve zall den Koninck aen de Hollanderen wederom restitueren ende soo een slaeff van de Konink diergelijck bestaet te doen, soo sullen de Hollanderen deselve aen den Koninck jusgelycx restitueren.

Soo er ijmandt aen de Hollanderen schuldigh is, zoo sullen het aen de Siabandar bekent maken en soo den Siabandar seijt: betaelt, soo sullen ze 't ook moeten betalen en soo de penningen dan niet voor den dagh en komen, soo sall den Koninck sijn hulpe daertoe contribueeren, omme deselve in te vorderen en soo het aen den Siabandar bekendt ' gemaeckt werde, zoo en sall den Koninck daer toe niet helpen en om dat het den Siabandar niet bekendt gemaeckt en is, so sullen dan die goederen ook verloren wesen.

Soo eenige menschen de Hollanders eenige molestie aendoen, deselve zall den koninck van Ziajacarata straffen nae de cosstumen van den lande; zoo de Hollanderen jegens de Javanen eenigh quaet moghten bedrijven, soo sall den $\mathrm{Cap}^{\mathrm{n}}$ de misdadigers daerover straffen.

Soo er eenige Portugesen off Casstilianen willen tot Ziajacarata ${ }^{2}$ komen handelen, hetselve sall haer den Koninck verbieden.

Dat is het accoordt van den koninck van Siacarata met de Hollanderen gemaeckt, soo en gelijck 't selve volcomentlijck bescreven is en is men hier over te vreden geweest, sonder datter eenige veranderinge kan in geschiede tot in eeuwigheijt toe. Was onderteeckendt Wizia Garama, koninck van Jacarata. Pieter Both.

1 Van der Chijs bldz. 203, heeft beter: „niet bekendt.”

2 Hier komen in het Contractboek eenige overtollige woorden voor, die de kopiïst bij vergissing er in heeft gevoegd. 


\section{MOLUKKEN.}

\section{Maart 1611. ${ }^{1}$}

Zooals bekend is, werd het Twaalfjarig Bestand tusschen Nederland en Spanje niet in praktijk gebracht in het Oosten. De Spanjaarden weigerden het te erkennen, zoolang zij geen bericht van hunnen koning hadden ontvangen, niettegenstaande de Nederlanders hun kennis hadden gegeven van de sluiting van het Bestand. (Zie Tiele, Europeërs, VIII, bldz. 122; onuitgegeven brief van den schipper van Der Goes aan de Bewindhebbers der Kamer van Middelburg, 9 September 1611, op het Rijksarchief). Beide partijen bleven in de Molukken bv. strijd voeren en trachtten zich daar te versterken. Aan deze staatkunde dankt ook onderstaand contract blijkbaar zijn ontstaan. Het werd gesloten met verschillende streken, van Gilolo, staande onder Ternate's sultan.

Contract ende eeuwigh verbondt gemaeckt bij den $\mathrm{Cap}^{\mathrm{n}}$ Corsen $^{2}$ uijt den naem ende van wegen de Mogeude $\mathrm{H}^{\text {ren }}$ Staten Generl der Geunieerde landen, als Hollandt, Zeelandt etca, Zijne Princelijcke Ex ${ }^{\text {tie }}$ als gouvern $^{\mathrm{r}}$ derselver landen ende $\mathrm{H}^{\text {ren }}$ Bewinthebberen der Oostindische Comp ${ }^{\text {ie }}$ ter eenre ende den sengage ${ }^{3}$ van Sebouge, ${ }^{4}$ de sengage van Touchwane, ${ }^{5}$ de senhage van Talo ${ }^{5}$ met den ganschen Raedt van deselve plaetsen, alsmede de noffamaniers ${ }^{6}$ van alle de omliggende steeden, sorterende onder d'voornoemden sengage van Sebouge ter andere zijde.

1 .

Eerstelijck belooven ende sweeren de bovengenoemde sengages en Raedt de Hollanders en den regerenden koninck van Ternate niet te verlaten maer in alles getrou te blijven, haer landt met lijff en leven te beschermen voort geweldt der Spangiaerden, Portugesen ende andere onse vijanden.

\section{2 .}

Datse niet en sullen vermogen, mette Spangiaerden in eenige onderhandelinge te treden, offte toelaten dat ze in eenige van de bovenverhaellde plaetsen sullen mogen komen om met haer eenige

1 Uit het Contractboek.

2 Zie hiervóór, bldz. 64, noot 1.

s Sengadji of sangadji $=$ hoofd van eene landstreek, districtshoofd.

4 Saboegoe.

${ }^{5}$ Misschien poeloe Toeakara ten noordwesten van Halmaheira, en Tolo aan de Oostkust van Halmaheira (Vgl. Tiele, Europeërs, VIII, bldz. 135.)

${ }^{6}$ Ngofamanjirah's = kamponghoofden. 
spraecke te houden tot aghterdeell van de Hollanderen, nogh veelle min aen haer eenige vivres te mogen verkopen, maer ter contrarie met alle maght ende onderstandt van de Hollanders t'selve beletten, waertoe wij, bovengenoemde sengages, versoeken, dat de Hollanderen hier datelijck een fordt sullen maeken ende met Hollandsche soldaten besetten tot verseekeringe van Sebouge voornoemt, het welck den voornoemde cap $^{n}$ beloofft van wegen $\mathrm{Sijn} \mathrm{H}^{\text {ren }}$ ende meesters alsoo te volbrengen. '

3.

Ende bij aldien eenigen paijs offte stillstandt van wapenen tusschen den koninck van Spangien ende de Hollanders is gemaeckt, offte nogh gemaekt soude mogen worden, soo beloofft den voornoemden $\mathrm{cap}^{\mathrm{n}}$, dat de voornoemde sengages met haer ondersaten de vrughten van die mede sullen genieten; soo de Spangiaerdt bovendien met wapenen ijets attenteerden, dat de Hollanderen met alle haere maght t'selve sullen wederstaen en wreecken.

4.

Oock en sall niemandt in sijn gelooff mogen gemolesteerdt offte bespot worden.

5.

Ende offt geviell datter eenige moeijten offte misverstandt ontstonde tusschen de Hollanders ende voornoemde vrunden, en sullen daerom d'een den anderen niet mogen affwijcken offte verlaten, maer met alle gevouglijckh ${ }^{t}$ 't selve modereren ende besleghten; ook sal men den persoon, daer de moeijten door ontstaen moght wesen, sijnen competenten reghter overleveren om daer van gestrafft te worden naer de misdaet vereijschen zall.

6.

Eijndelijck dat de Hollanders met de voornoemde sengages ende haer geallieerde vrunden ende vasalen sullen verbonden ende gehouden wesen ende mits desen verbinden te onderhouden ende doen onderhouden een eeuwige verbintenisse van vrindschap, conversatie ende handelinge; oock dat de Hollanders voornoemt aen de bovengenoemde vrinden tot allen tijden sullen doen alle hulpen, faveur ende bijstandt om te helpen defenderen naer alle haer vermogen tegen elcx een ygelijck onser vijanden, die aen de voornoemde

1 Deze belofte is nagekomen, maar nog in hetzelfde jaar 1611 is onze versterking bij Saboegoe door de Spanjaarden genomen (Zie Tiele, Europeërs, VIII, bldz. 122. Vgl. t. a. p., bldz. 135). 
sengagie, sijne onderdanen offte Hollanders voornoemt in eeniger manieren soude soeken offte traghten te offenceren offte beschadigen; het welck in aller wegen de Hollanders ende de voornoemde sengage met alle haere geallieerde vrinden sullen verbonden blijven te onderhouden ende verdefenderen. Tselve boven verhaeldt is onder belofftenisse van getrouwigheijdt, eere ende woordt die wij beyde aen Godt ende onsen evennaesten schuldigh zijn.

Aldus gedaen in de stadt van Sebouge liggende op 't vasste landt tegen over $t$ eijlandt van Ternaten ende van wedersijde bij ons onderteijckent, op den $26^{\text {e }}$ dagh van Maerdt jnt jaer onzes $\mathrm{H}^{\mathrm{ren}}$ 1611. Onderteijckent Adriaen Corsen. Lager stondt een zegell met Hebreusche ${ }^{1}$ letteren van de overste onderteijckent.

\section{JAPAN.}

30 Augustus 1611. ${ }^{2}$

Als leider der Nederlandsche factorij te Hirado werd aangesteld de opperkoopman Jacques Specx (1609-1613). In Juni 1611 begaf hij zich op een z.g. hofreis naar Soeroega (thans Shidzuoka), ten Zuidwesten van Jokohama, waar de Shogoen dikwijls verblijf hield, om de belangen van den Nederlandschen handel bij de Japansche autoriteiten verder te behartigen. De shogoen Iyeyasoe ontving hem vriendelijk en verleende den Nederlanders een nieuwen handelspas. (Vgl. Nachod, Japan, S. 115, f., $141-149)$.

D'Hollandsche schepen comende in mijn land van Japan, 't sy oock op wat havenen en plaetsen het mede mogen wesen, bevelende by deeze wel expresselyck aen alle en een iegelijk onder myn gebied sorterende, deselve in geenerleij manieren te aggraveren, of te empecheren, maer ter contrarie alle hulp, faveur en adsistentie in 't geene versoeke[n] te betonen; een iegelyk sig waghtende anders als alle vriendschap hun luyden op mijn woord toegeseght, te onder-

\footnotetext{
1 Sic! - De kopiïst van het Contractboek heeft de Arabische karakters voor Hebreeuwsche aangezien. Dit was zeker Herbert de Jager niet.

2 Ik ontleen onderstaande vertaling aan aanteekeningen, volgende op een "Extract missive geschreven uyt Japan den $18^{\mathrm{n}}$ October 1693 aen Haer Hoog Edns op Batavia," door mij aangetroffen in het archief der familie Huydecoper van Maarsseveen (Vgl. nog Nachod, S. XIX en de óók daar aangehaalde werken: A. Montanus, Gezantschappen, bldz. 195 en Kämpfer, Japan, bldz. 272 , en Tafel XX).
} 
houden, wel toesiende myne woorden en beveelen niet gevioleert werden.

Gedateert stijlo Japan $25^{\text {ste }}$ dag der $7^{\text {de }}$ maene. Sijnde den 30 Augustus 1611. 1

\section{CEILON.}

\section{Mei 1612. 2}

Nadat het Twaalfjarig Bestand was gesloten, zonden op verzoek van de Bewindhebbers der O.I. C. de Staten-Generaal en Prins Maurits brieven aan verschillende Oostersche potentaten, om deze gebeurtenis bekend te maken en van de noodige commentaren te voorzien. Ook voor den maharadja van Kandy werden missives aan Pieter Both medegegeven, toen deze in Januari 1610 naar Indië vertrok en duidelijk werd daarin het wantrouwen uitgesproken, dat men in Nederland koesterde ten opzichte van de koloniale staatkunde van Spanje-Portugal. Bevestiging van de „verbonden" tusschen Nederland en Ceilon werd daarom gezocht. En de Maharadja, steeds met de Portugeezen in strijd, ging op dit denkbeeld gaarne in, toen Marcellus of Marcelis de Boshouwer of De Boschhouwer in 't begin van 1612 zijn hoofdstad bezocht en hem de brieven overreikte. (Vgl. Baldaeus, Malabar-Ceilon, bldz. 23-26; De Jonge, Opkomst, III, bladz. 135; IV!, bldz. I, v.: Van Geer, Ceilon, bldz. 23).

1. Het Verbond zal onverbrekelijk en vast zijn.

2. Alle daden van vyantschap, te vooren gepleeght, zullen ophouden en vergeten zijn.

1 Aan deze vertaling gaat vooraf: „Ten tyden van den E. Jacobus Speks, $A^{\circ} 1611$, die 't comptoir in Firando stabileerde, is aen d'E. Comp ${ }^{\circ}$ een Pas of Gossingh door den Japanse Keiser Ongiosamma, of liever Gonging Samma verleent, om alomme in sijn rijk den handel te drijven en luyd als volgt."

Deze bewoordingen komen nagenoeg overeen met het opschrift „op de enveloppe van den Pas" (van 1609): volgens Lauts (Japan, bldz. 171). Zou hier niet liggen de sleutel ter verklaring van den passen-strijd ? Blijkbaar was in 1693 nog de pas van 1611 in de goede nenveloppe" besloten. Toen Lauts ongeveer 1847 daarnaar informeerde, was de pas van 1609 geraakt in den omslag van 1611, de pas van 1611 elders terecht gekomen of verloren geraakt. De woorden van den pas, zooals die bij Lauts, bldz. 171-173 (in den tekst) voorkomen, slaan niet op den pas van 1609 , maar op dien van 1611. $\mathrm{Zij}$ komen ook geheel in zin overeen met den pas, zooals ik dien hier boven geef en Lauts spreekt niet over een pas van 1611, geeft daarvan althans den tekst niet. Vgl. ook Begin ende Voortgang, II (Verhoeven), bldz. 93. Onder "Gonging Samma" moet zeker worden verstaan de eeretitel Gongensama, aan Iyeyasoe na zijn dood gegeven. (Nachod, S. 165).

2 Onderstaande korte inhoud van een "verbont" tusschen den maharadja van Kandy en de O.I. C. ontleen ik aan Baldaeus, Malabar-Ceylon, bldz. 26-28. Van Dijk, Wemmer van Berchem, bldz. 28, noot 1), dateert het verdrag op 11 Maart 1612. 
3. Zoo den Portugees Zijn Majesteyt quam te beledigen, zullen de E. Heeren Staten Zijn Majesteyt met alle middelen van oorloge behulpzaam zijn, om op het krachtighste te helpen.

4. Zijn Majesteyt zal toestaen, dat wy een fort op Cotiarum ${ }^{1}$ zullen mogen maken, midts dat de koning ${ }^{2}$ van Cotiarum zijn tollen, vruchten, en inkomsten des landts zal behouden.

5. Den Keijzer zal nodige materialen en stoffe van kalk en steen tot ophouwinge van de voornoemde sterkte verschaffen; alsmede coeleys ${ }^{3}$ of arbeyders, die bij de E. Compagnie zullen betaelt werden.

6. Zijn Majesteyt zal in Candy en andere plaetzen, (tot verzekering van de E. Compagnie koopmanschappen) verzorgen dat steene pakhuyzen gemaekt zullen werden, om voor de brand verzekert te zijn.

7. Zijn Majesteyt zal onze schepen en volk, met alle kracht tegen het gewelt der Portugezen zoeken te beschermen, en zoo zullen aan de andere zijde de Nederlanders met alle kracht doen.

8. Zijn Majesteyt zal, in zaken van oorloge, tusschen ons gemeyn, niet voornemen, zonder kondschap van de Heeren amptenaren, in dienst van de E. Compagnie aldaer zijnde, dies in Zijn Majesteits krijgs-raad twee Nederlanders zullen zitten, om alle zaken van oorlogh met gemeyn besluyt af te handelen.

9. Zijn Majesteyt zal gehouden zijn, de koopmanschappen met lastdragend vee na boven te voeren en de gekochte waren wederom op het strant in Cotiarum (buyten onkosten van de E. Compagnie) te brengen.

10. Bij verongelukken van schepen, chaloupen en bootjes zullen de onderdanen van Zijn Majesteyt gehouden zijn, de goederen te bergen en zonder onkosten ons weder in handen te leveren.

11. De Nederlanders zullen met vrede haar goederen mogen uytvoeren, zonder eenige tollen te betalen.

12. Alle de onderdanen van Zijn Majesteyt, zonder onderscheyt, zullen met de E. Compagnie onverhindert mogen handelen.

13. Zijn Keyzerlijcke Majesteyt zal alle zeldzamen en ongemeyne dingen, uyt Nederlandt komende, aanvaarden in zulken prijze, als met de E. Compagnie in ruylinge van andere waren zal konnen over een komen.

\footnotetext{
1 Koddiyarap.

2 De radja.

3 Een woord vermoedelijk van Vóór-Indië afkomstig. (Vgl. Hobson」Jobson, p. 192).
} 
14. Zijn Majesteyt zal jaarlijks zooveel van den besten caneel aan de E. Compagnie leveren, als te bekomen zal zijn; en deze caneel zal of met contanten ofte andere koopmanschappen betaalt werden tot een gezette prijs, die onder den anderen zal beraamt werden.

15. Men zal geen andere perzoonen, die in besluyt ${ }^{1}$ van koopmanschappen met de Nederlanders getreden zijn, mogen goederen te leveren, voor en al eer de Nederlantsche handelaars voldaan zijn; en zoo bevonden werde het tegendeel te geschieden, dat men vrij, zoo haar goederen als perzoonen, zal mogen aantasten, om alzoo de zelve tot onderhoudinge van het verbond te dwingen.

16. Zijn Majesteyt zal geen Europeisch volk in zijn land laten handelen zonder bevel en last van haar E. Hoogh-Mog. en zijn Princel. Excell.

17. Zijn Majesteyt zal tot bouwen van schepen, jachten, etc. een goet en bequaam aental van hout beschikken, en 't zelve bezorgen aen strant te doen brengen.

18. Alle gevangenen aan wederzijden zullen ontslagen werden, en volkomen vrijheijt bekomen. ${ }^{2}$

19. De Nederlandtsche dienaren zal Zijn Majesteyt gantsch geen gewelt aendoen; en zoo de zelve haar ergens in te buijten gingen, zullen dezelve door de Nederlantsche hoofden over hare misdaad gestraft werden; dies zal het zelve ook plaets hebben omtrent de onderzaten van Zijn Majesteyt.

20. Zijn Majesteyt zal gehouden wezen, gesteenten en peerlen alleen aan de Nederlanders te verkoopen; zo blijven ook de Nederlanders gehouden aan Zijn Majesteyt te leveren alle juweelen, kostelijkheden, en zeltzame dingen, midts de waarde van dien betalende, gelijk te vooren is aangeroert; en of men niet konde over-een-komen in deze koopmanschappen, zal evenwel de vrientschap ongeschent blijven.

21. Zijn Majesteyt en de Heeren Staten zullen alle vrientschap en minzaamheyt onderhouden, en men zal den anderen met raad en daad in alle voorkomende zaken bij staan.

22. Alle vyantlijke daden, zoo aan de eene als aan de andere zijde, zullen t'eenemael zijn vergeten en vergeven.

23. Niemandt dan Zijn Majesteyt zal vermogen eenig geld te munten of hooger 't zelve doen uijtgeven, als bij Zijn Majesteyt en

1 De zin is hier minder duidelijk.

${ }^{2}$ Wat hiermede wordt bedoeld, is mij niet duidelijk. Of waren misschien nog lotgenooten van De Weerdt op Ceilon gevangen?

$7^{\circ}$ Volgr. III. 
Nederlanders, in gelegentheyt van het geld 't welk uyt Hollandt mochte komen, zal gesteld zijn; en zoo yemand van wederzijden bevonden wierd valsch geld geslagen te hebben, dat met de dood zal gestraft werden.

24. Zijn Majesteyt en de Nederlanders zullen met malkanderen overleggen, wat ten besten nutte wederzijds dienstig ware, in den handel van grooter of minder munte.

25. Dat de munte, die in den gank nodigh wiert geacht, alle drie jaren zoude werden verandert, te weten drie jaar in Candy, en drie jaar in onze verblijf-plaatzen.

26. De voorsz. gelden ${ }^{1}$ zouden wederzijds op- en af-gezet worden, ten profijte van oorloge.

27. Dat alle Indische volkeren met hare vaartuygen zouden vermogen in Zijn Majesteyts landen te komen, gaan en vertrekken, om haar koopmanschappen te doen, zonder eenige tollen te betalen, en dat voor den tijdt van drie jaren.

28. Na verloop van de voornoemde drie jaren zal Zijn Majesteyt met de gelaste van haar Hoogh-Mog. en zijn Princel: Excellentie mogen besluyten, dat tollen op alle goederen tot welvaren van Zijn Majesteyt, en onderhoudt dienen gestelt en ingevoert te werden.

29. Zijn Majesteyt zal van alzulke tollen hare Hoogh-Mog: en Zijn Princel: Excellentie laten genieten de gerechte helft, waar toe ontfangers en schrijvers wederzijdts zullen gestelt werden.

30. Van alle goederen die omtrent de heerschappye van Ceylon, zullen werden verovert, Zijn Keyzerlijke Majesteyt en hare HooghMog: en zijn Princel: Excellentie, zullen de helft genieten, midts de gevangenen voor zoen-geldt lossende, zonder die te dooden.

31. Alle die van hare Hoog-Mog: en Zijn Princel: Excellentie af-gevaardight zijn, zullen aan zijn Majesteyts onderzaten vry geley geven om te handelen, gelijk Zijn Majesteyt aen zijn inwoonderen buyten 's Landts handelende, oock gehouden zal zijn te doen; zonder welk vry-geley de zelve zullen mogen werden aangetast, ende haar waren voor buyt verklaart.

32. Zijn Majesteyt ende de Hoog-Mog: ende Zijn Princel: Excellentie zullen trachten alle de gangen en doortochten, zoo ter zee als te lande, binnen het eylant Ceylon reysbaar en doortrekkelyk te maken, midts weerende alle struykroovers en landtloopers, zooveel mogelijk zal zijn; dies Zijn Majesteyt zal gehouden zijn timmerhout

Welke? 
te verschaffen, tot opbouwinge van galeyen, fusten ${ }^{1}$ en andere vaartuygen, om daar mede de zee te beveyligen; en wanneer zulke roovers, 't $\mathrm{zy}$ te water of te lande werden aangehaalt, die met de doodt (andere tot een voorbeeld) te straffen.

33. Om het voorsz. verbond heylig en onverbrekelijk te onderhouden, zoo belooft de Keyzerlijke Majesteyt, als mede de HoogMog: Heeren Staten Generaal en Zijn Princel: Excellentie, met alle kracht het zelve te behertigen, en geenzins te lijden ofte te gedulden, dat daar tegen zal gezondight werden, beloovende de overtreders (aan beyde zijden) op het hertste en zwaarste te doen straffen en door haar volkomentlijk de schade vergoeden.

\section{MOLUKKEN.}

\section{December 1612. 2}

De eerste gouverneur-generaal, Pieter Both, was al spoedig na zijne komst in het Oosten naar de Molukken gegaan, om daar orde op de zaken te trachten te stellen. Hij kwam bij Ternate in September 1611 en de vijandelijkheden met de Spanjaarden werden voortgezet, toen het bleek, dat het Bestand niet was erkend. Both trachtte de positie der onzen zooveel mogelijk te versterken, o. a. door het bevestigen der vroeger gesloten contracten: ook met Batjan (Vgl. Tiele, Europeërs, VII, bldz. $122-125$.

Contract gemaeckt bij den $\mathrm{H}^{\mathrm{r}}$ Gouvern ${ }^{\mathrm{r}}$ Gener ${ }^{\mathrm{l}}$ met den coninck en princepale van Batchian.

Op huijden den $2^{\mathrm{e}} \mathrm{X}^{\text {ber }} 1612$ sijn vergadert geweest de gestrenge ende manhaffte heere Pieter Both, gouvern ${ }^{\mathrm{r}}$ generaell in de quartieren van Indië wegen $d^{\prime} E d^{e}$ Mogende $\mathrm{H}^{\text {ren }}$ Staten Generaell der Vrije Vereeuighde Nederlandse provintien, sijn Princelijcke Ext ende de Heeren Bewinthebberen der Generaele Oostindische Compe ter eenre ende de maghtige koninck ${ }^{3}$ Nouroe Solaedt, koninck van Batchian, ende sijnen adell ter andere zijde ende hebben aldaer het accoordt, voor desen van den viceadmirael Symon Janszoon Hoen met hem gemaekt ${ }^{4}$, geresumeert ende bevestight, resumeren ende bevestigen mits desen, beloovende hetselffde in alle sijne ar-

1 Het Portugeesche fusta, een klein roei- of zeilschip.

2 Uit het Contractboek.

3 Sultan.

4 Hiervóór n XXXIV. 
tykelen van beijde zyden naer te komen; ende tot meerder verseekerheijt van onse onderlinge begonnen vriendschap, soo heefft den $\mathrm{H}^{\mathrm{r}}$ gouvern ${ }^{\mathrm{r}}$ generaell Pieter Both ter eenre zijde beloofft ende sweerdt mits desen, de voorschreven coninck en coninkrijcke van Batchian in hare gereghtigheden tegens alle jegenwoordige haere ende onse vijanden, offte die hen hier naer tegens hen zouden komen te verheffen, voor te staan ende te defenderen ende soo veell alst doenlijk is sijne maght te helpen amplieeren ${ }^{\mathbf{1}}$; ende den voorschreven coninck met alle sijne princen ende heeren ter andere zijden hebben beloofft ende gesworen met solemnele ende ${ }^{2}$ op haren alcoran, belooven ende sweeren mits deze, den koninck ende coninckrycke van Basian, gehou en getrouw te zijn tot dienste van de $\mathrm{Ed}^{\text {en }} \mathrm{H}^{\mathrm{ren}}$ Staten Generael, sijn Princelijcke Ex ${ }^{\text {tie }}$ ende de Heeren Bewinthebberen, waermede sij als nu in een verbondt zijn, deselve niet aff te gaen ende eenige van hare vyanden aen te hangen, alsmede geen correspondentie met eenige der voorschreven $\mathrm{h}^{\text {ren }}$ vijanden te houden ende in somma jnt minste met den vijandt niet te practiceren het geene tot prejuditie van den voornoemde konink ende onsen standt alhier in India souden mogen strecken. Is mede een maedt geraemdt aengaende de sagou', waervan twee ijsere dubbelen zijn gemaeckt ende d'eene int huijs van de Comp ${ }^{\mathrm{e}}$ ende den ander bij den Koninck zall worden bewaerdt, waernaer den ferde ${ }^{3}$ sagou sullen moeten werden geformeerdt, die de voornoemde coninck ende zijne $\mathrm{H}^{\text {re }}$ belooven voortaen voor een halve $\mathrm{R}^{\mathrm{a}}$ van $8^{\text {ten }}$ aen de Compe $^{\text {e }}$ te leveren. Aldus gedaen op 't eylandt Laboua in Batsian ten daege, jaere en maendt als boven. Was onderteijckent Piero ${ }^{4}$ Both ende gedruckt met het zegell van de Compe.

\section{KUST VAN KOROMANDEL.}

12 December 1612. 5

In het midden van 1611 vertrok Wemmer van Berchem van Bantam naar de Kust van Koromandel en in het volgende jaar nam hij het Directeurschap op zich over onze kantoren dáár, toen reeds ten getale van minstens vier, in verschillende rijken gelegen, nl. Tegenapatnam (met Tirepoplier), Pulicat, Petapoeli (Nizampatam) aan de Kistna delta

1 Portugeesch ampliar $=$ vermeerderen.

2 Schrijffout voor: eede?

3 Vgl. De Clereq, Maleisch der Molukken, bldz. 16, sub voce "fardoe".

4 Sic!

5 Uit het Contractboek. 
en Masulipatam, ten Noordoosten van Petapoeli. Den 9 Juli 1612 werd ons hoofdkantoor op de kust, dat te Pulicat, door de Portugeezen veroverd. Van Berchem, die het belang dezer vestiging zeer goed inzag, wendde zich tot den vorst van Carnatica en sloot onderstaand contract. (Vgl. Van Dijk, Wemmer van Berchem, bldz. 17-27, 29, noot 1.).

Accoord ende contract gemaekt bij den directeur Wember van Bergen wege ende uijt chraght d'Ede hooge gemelte $\mathrm{H}^{\text {ren }}$ Staten ende sijne Princel. Ex ${ }^{\text {tie }}$ Mauritius v. Nassou ecta ende authoriteijt van de E. $\mathrm{H}^{\mathrm{r}}$. Pieter Both, gouvern ${ }^{\mathrm{r}}$ gener $^{\mathrm{l}}$ over de Hollandts Jndien ter eenre zijde ende den doorlughtigen hooghgebooren coninck genaemdt Vincata Patij Raija Lou ', coninck over de landen Carnatijea, Sinruasina, Patij ${ }^{2}$ ende meer andere heerlijckheden ter andere zijde ende dat voer eeuwigh ende onverbreklijck. Desen $12^{\text {e }} \mathrm{X}^{\text {ber }} \mathrm{A}^{0}$ 1612. In Velover ${ }^{3}$.

Allsoo de Portugesen van St. Tome ${ }^{4}$ op den $9^{\text {e }}$ Junij deses jaers t' cantoor generaell tot Palliacatta voorschreven geraseerdt hebben ende des Comps goederen geroofft, eenige vant volck dootgeslagen, den opperkoopman, genaemt Adolff Thomaszoon, ende d'reste naer St. Thome gevancklijck mede genomen, oversulcx genoodtsaeckt de novo met den voorschreven koninck te contracteren in forma als volght:

Eerstelijck sall den Koninck ${ }^{5}$ toelaten dat de koninginne gen $^{t}$ Obayama ${ }^{6}$ tot Palleacatta voorschreven de begonnen fortresse aldaer op haeren cost sall laten opbouwen ende doen volmaeken ${ }^{7}$, mede deselve met haer volck doen bewar ${ }^{\mathrm{n}}$, dan $\mathrm{s}^{1}$ gehoud $^{\mathrm{n}}$ wesen alle avondt de sleutels van de poort in onse handen te leveren om deselve smorgens aen den portier daertoe gestelt, beneffens den onsen, die wij daertoe sullen setten, de voorschreven poorten te openen ende

1 Van Dijek leest: „Vencata Patiraiabou." Vgl. hiervóór, bldz. 84.

2 Vgl. hiervóór, bldz. 84, v.

3 Van Dijk, t. a. p., bldz. 25, leest foutief "Collour." Het is Vellore $\left(12^{\circ} 55^{\prime}\right.$ NB.), in die dagen een der zetels van den radja van Vellore (Carnatica, Chandragiri, Vijayanagar.) Vgl. hiervóór, bldz. 83 .

4 Ten Zuiden van Madras. Ook geheeten Maliapoer of Meliapoer.

5 Van Carnatica.

- Van Dijk spelt deze naam verschillend: Oba Jema, enz. Volgens een Nederlandsch bericht van 1615 (van Antonio Schorer) was Pulicat ,toekomende eene van de vrouwen van den Koning van Velour" (Vellore). Zie van Dijk, bldz. 19.

7 Het werd het bekende fort Geldria (Van Dijk, 29, v). 
des avondt te sluijten ${ }^{1}$. Voorts sullen wij tot onsen gebruycke hebben de helfft van 't fordt voornoemt, daer zijn Princelijcke Ex ${ }^{\text {tie }}$ tot synen gelieven sall vermogen te hebben een steenen huijs, om alle ammonitie van oorloge, kruijdt, loodt, kogels, londt, anckers, touwen, zeylen ende alle andere koopmanschap te mogen bewaren voor brandt, rovers, dieven ende meer andere ongelucken.

Nogh beloofft den Koninck aen den direct $^{r}$ voornoemt ons volck, door de Portugesen in sijn landt tot Palliacatta gevangen, weder in onse handen te doen leveren ende daer beneffens te procureren onse goederen, door de Portugesen genomen, ons weder te doen restitueeren.

Voorts sullen wij, Hollanders' en Zeelanders ende alle die geene die van wegen de generale Comp ${ }^{e}$ hier traffiquerende, gehouden wesen te betalen voor alle goederen ende coopmanschappen, die hier gelosst sullen worden, een en een halff ten 100 ende die geladen sullen worden twee ten 100 , wel [ver]staende t'geene dat eens betaelt heefft niet meer en sall betalen. Oock geldt, rijs ende andere behoefften voor haer huijs sullen niet betalen.

Den Koninck zall niet mogen eenige Portugesen te laten wonen offte handelen in Palleacatta, maer ter contrarie haer 't selve te verbinden ${ }^{2}$.

Niemandt aen beyde zijde zall niet vermogen eenige questie, arguatie offte disputatie van de religie te maeken.

Soo daer ijmandt hem begave door eenigh quadt feijt over te loopen bij den Koninck offte int landt, soo zall den Koninck gehouden wesen, deselve over te leveren in handen van onse natie.

Voorts sullen alle persoonen en koopluyden vermogen met ons te handelen, koopen ende verkopen alle koopmanschappen ende goederen, zonder dat ymandt sulcx soude mogen verbieden.

Alle schillders ende wevers, die eenige obligatie met den Directeur offte Capteijn allhier sullen maeken van wegen eenige kleeden te schillderen offte doeken te leveren, sullen gehouden wesen het selve naer te komen ende bij faullte van dien sall den Capiteijn, die allhier is blyvende, vermogen deselve aen te laten tassten ende alhier in de boeijen vermogen te stellen, waer over den Koninck sall gehouden wesen corte expeditie te laten doen ende haer het selve laten naerkomen, alles soo het dan geaccordeert sall wesen.

Ook en sall den Koninck niet vermogen hier te laten handelen

' De zin is wat bedorven maar toch volkomen duidelijk.

2 Moet natuurlijk zijn: "verbieden." 
eenige Europische natie dan alleen die bescheijt van sijne Princelijcke $\mathrm{Ex}^{\text {tie }}$ brengen.

Oock soo belooven wij van wegen de Generale Comp ${ }^{\mathrm{e}}$ aen ${ }^{\mathbf{1}}$ den Koninck eenige goederen, geschut, ammonitie van oorloge offte andere frayigheden uijt onse landen begeerdt te ontbieden, soo sullen wij deselve gehouden wesen hier met d'eerste gelegendth te brengen, voir dewelcke den Koninck sall gehouden wesen te betalen gelijck het in ons landt gekoosst heefft.

Oock sullen wij vermogen op de rheede van Palliacatta, St. Thoome ende alle andere havenen ende plaetsen des voornoemden Koninghs te mogen beschadigen, aenhalen ende alle hostiliteijt op de Portugesen scheepen ende goederen te gebruycken, zonder daer int minste ijets tegen te seggen offte ons eenigh beletsell offte schade daerom te doen; aengesien de trevis, door den koninck van Spangien met de hooggemelte Edele $\mathrm{H}^{\text {ren }}$ Staten ende zijne Princel. Ex ${ }^{\text {tie }}$ gemaeckt, de Portugesen voorschreven ende Castilanen alhier in Indien volgende het gecontracteerde niet en observeren maer ter contrarie de fracteurs ende breekers van de trevis zijn.

Alle de schepen, die van hier naer andere plaetsen sullen zeylen met paspoordt van den Directeur offte Capitayn, en sullen onse natie niet vermogen eenige schade de doen.

Ende allsoo Palliacatta voorschreven verre van den Koninck is gelegen, beloofft ons mits desen, datt wij staen sullen beneffens hem onder de bescherminge van Jageragie ${ }^{2}$, die ons in alle swarigheydt ende voorvallende occurrentien sall beschermen jegens alle quattwillighe offte vijanden, die ons met geweldt offte practyquen eenigh hinder soude willen aendoen, waervan den voorschreven Jageragie ons sijn kaull sall verleenen tot onser versekeringe ende gerustheijdt.

Alle welcke voorschreven contract jck, Vincaty Patij Raija Alou, kouinck over de landen van Carnatica, Sinruas-sijna, Patij ende meer andere heerlyckheden, beloove nu nogh nimmermeer te breken, het welck ick zweere bij mynen Godt Perumaell. Jck, Wember van Bergen, directeur ende contractant van wegen de Generaele Oostjndische Comp ${ }^{\mathrm{e}}$, beloove ${ }^{3}$ mede 't zelve nu nogh nimmermeer te breken, soo waerlijck moet mijn Godt helpen. Was geteyckent

1 Lees: „als."

2 Wie met dezen radja wordt bedoeld, is mij niet duidelijk. (Vgl. echter van Dijk bldz. 24, 27.) Hij was blijkbaar gouverneur van Pulikat.

s Van Dijk, t. a. p., bldz. 27, leest rgeloove" en knoopt daaraan een niet onvermakelijke, maar onjuiste, opmerking vast. 
Wember van Bergen ende tot meerder verseekeringe van deseu heefft ons Zijne May ${ }^{t}$ zijn zeegell in rooden lack met syn eygen handt hier onder selffs gedruckt ende daerenboven heeft ons nogh sijne handt, gedruckt op een doeck, gegeven, dat men noemt de handt van sandell. 1

\section{BOETON.}

5 Januari 1613. 2

Op last van den GG. Pieter Both deed de kapitein Apollonius Scotte op zijn tocht van de Molukken naar Solor (begonnen 9 November 1612) Boeton aan, om met den radja van dit eiland „een contract ende eeuwich verbondt te maecken." Nadat hij den $17^{\mathrm{n}}$ December vóór Boeton was gekomen, gelukte het hem al spoedig, het onderstaande contract te sluiten. (Vgl. Tiele, Bouwstoffen, I, bldz. 12-13, Tiele, Europeërs, VWI, bldz. 135-137.)

Contract ende eeuwigh verbondt, gemaeckt bij den command $^{r}$ Apolonnius Schotte, als last hebbend van d' $\mathrm{H}^{\mathrm{r}}$ gouvern $^{\mathrm{r}}$ gener $^{\mathrm{l}}$ Pedro ${ }^{3}$ Both, uyt den naem van de Mogende $\mathrm{H}^{\text {ren }}$ Staten Generl der geunieerde Nederlanden, mitsgdd ${ }^{\mathrm{rs}}$ Sijn Princelijcke Ex ${ }^{\mathrm{tie}}$, als Gouverṇ ${ }^{\mathrm{r}}$ der zelver, en de $\mathrm{H}^{\text {ren }}$ Bewinthebberen der Oostjndische Comp $^{e}$ ter eenre ende den grootmaghtigen konink van Bouton ter andere zijde.

In den eersten soo beloofft den Command ${ }^{r}$ aen den koninck van Bouton, uijt den name voorschreven, dat de Hollanders zijne ondersaten ende landt zullen helpen beschermen tegen alle jnvasie ende sulcke vyanden als hem op sijn landt zoude willen beschadigen offte hinderlijck vallen ende zall tot dien eynde op de strandt van des Konings ondersaten twee bolwercken opgemaeckt worden, op dewelcke den Command $^{r}$ voor eerst sall versorgen vier stucken geschuts met hare toebehooren als oock eenige Hollanders om deselve te regeren ${ }^{4}$.

Ten tweede soo beloofft den Command ${ }^{\mathrm{r}}$, den staet en strandt van dit coninckrijck mitsgd ${ }^{\mathrm{s}}$ sijne gelegenth ${ }^{\mathrm{t}}$ aen den $\mathrm{H}^{\mathrm{r}}$ Gouvern ${ }^{\mathrm{r}}$

1 Vermoedelijk is dit de afdruk van 's Konings hand, gedrukt in het welriekende sandelhoutpoeder.

2 Uit het contractboek. De datum is niet geheel zeker: 5 of 8 Januari.

${ }^{3}$ Misschien is het contract in het Portugeesch of Spaansch opgemaakt.

- Dit gebeurde al zeer spoedig, nog in 't begin van 1613. Vgl. Tiele, Bouwstoffen, I, bldz. 33, v. 
Generaell voor te dragen, meerder guarnisoenen versoeckende, insonderh $^{t}$ dat met den eersten een schip offte jaght gesonden moght worden tot hier, omme het meer noodwendighe tot welstandt van beijde de natie ${ }^{1}$ te helpen bereghten.

Ten derden beloofft te jntercideren bij den koninck van Macassar, ten eynde hij desisteere van alle hosstiliteijt ${ }^{2}$ tegen den koninck van Bouton offte eenige zijne onderdanen, tot wat eynde op 't spoedighste een prauw met schryven aen den selve koninck sall affgeveerdight worden ende sullen den koninck van Bouton beschermen tegen alle gewelden.

Ten vierden sullen [zij] ${ }^{3}$ den Koninck ende zyne onderzaten niet hinderlijck werden in hare religie, politie offte regeringe, maer sullen de + van de Hollandse natie in ijets onredelijck, streckende tot oneenigheijt tegen 't selve bestonden, daer over van haere competenten reghten gestrafft worden. Van gelijcken sullen de Mooren, soo yets tot nadeell van de Hollandsche bestonden, van den Koninck offte hare competente reghteren gestrafft worden.

Ten vijffden soo belooven, bij den grootmaghtigen coninck van Ternaten te versorgen, dat sijne ondersaten den koninck van Bouton offte sijne ondersaten geen overlast aen doen sullen ${ }^{5}$, maer dat den koninck van Ternaten sijne zaeken bij den koninck van Bouton ordentelijck sall bereghten, 't zij met geauthoriseerde gesanten offte door missive met sijnen konincklijken zegell versegelt, all soo bij wijle des Konings naem ende authoriteijt van sommige misbruijkt is geweest.

Ten sesden sullen de Hollanders tot gerieff van beijde de natiën, ten eijnde bequamelycker de coophandell ende entrecours magh onderhouden werden, met d'eerste gelegentheijt versorgen, dat hier gebraght werde een goede quantiteijt van casges ${ }^{6}$ offte andere copere munte, welcke munte offte casges den Koninck beloofft

1 Valentijn, I, b, bldz. 246, heeft: "natien."

2 Vgl. Tiele, Europeërs, VIII, bldz. 136.

s Vgl. Valentijn, t. a. p.

"Valentijn: "zoo die."

5 De sultan van Ternate had vroeger Boeton tot zijn gebied gerekend. In het Onuitgegeven journaal van Pieter van den Broecke (Leidsche Universiteitsbibliotheek) lezen wij: „Dit coninckrijck (Van den Broecke bezocht het in Maart 1615) stondt te voren onder den conninck van Tarnata, dan sedert dat dit rijck heeft beginnen te declineren, is elck op hen selven geweest, hoe wel noch groot vrindschap met den anderen houden."

6 De zg. "cassies ofte pitjes" (Encyclopaedie, II, bldz. 592; Hobson-Jobson, p. 128). 
onder zijne gemeente gangbaer te doen werden naer advenandt de $\mathrm{R}^{\mathrm{a}}$ van $8:-1$.

Ten zevenden zoo belooven de Hollanders, 't fordt gemaeckt sijnde, de jnlanders geen overlast te doen, mede niet toetelaten dat eenige vreemde natie, hier komende, den Koninck offte zijne onderdanen sullen eenige overlast doen.

De Konincklijcke $\mathrm{May}^{\mathrm{t}}$ voornoemt verclaert ende segt mits desen, de Hollandsche natie hier geroepen te hebben, om sijn konincklijcke ${ }^{2}$ te helpen beschermen tegen sijne vijanden, die hem offte d'jnwoonders souden willen beschadigen, als mede om een offensyff en dyfentyff oorlogh te voeren tegen de vyanden van den groot maghtige koninck van Ternaten, metten welcken in vrundschap ende eenigheijt sall continueeren naer ouder gewoonte ${ }^{3}$, mitsgaders tegen die de Hollandsche natie hier omtrent souden willen beschadigen offte hinderlijck vallen.

Ten tweeden beloofft Sijne Maijt, de Hollanders te assisteren op den toght van Solor, die nu voor handen is, ${ }^{4}$ met well gemande corre-corren. Beloofft mede Sijne $\mathrm{May}^{\mathrm{t}}$, geen andere natie eenigen handell off traffyquen toe te laten, die de Hollanders zouden nadeligh worden ende zullen de Hollanders als beschermers van dit koninckrijck de preferentie genieten.

Ten derden beloofft Zijne May ${ }^{t}$, een prijs te stellen op de coopmanschappen ende vivres in zijn landt vallende, welcken prijs zall onderhouden werden ende zullen de Hollanders in dit coninckrijck mogen gaen ende komen ende haren handell drijven, zonder eenige tollen offte schattinge te betalen; ende zullen deselve op het landt van Bouton mogen zaijen ende planten ende hun gewassen genieten in alle zekerheijt ende vrijheijt neffens zijne onderzaten zonder ijmandts tegenspreken, mits dat zij zulcx den Koninck zullen moeten te kennen geven. Mede zoo vergundt den Koninck aen deselve Hollanders alle geniet en vryheijt van zyne rheeden ende

1 Toen Scotte op Boeton kwam, trof het hem, dat de bewoners „bij gebreck van eenige munte, haar daer behielepen met laepkens, in plaetse van gelt." (Vgl. Tiele, Bouwstoffen, I, bldz. 12, v.)

2 Koninckrijek (Valentijn, t. a. p. bldz. 246.).

$\$$ Vgl. noot 5 op bldz. 105.

4 Het plan tot eene expeditie der Nederlanders naar Solor, om de Portugeezen dáár aan te tasten, was opgevat juist op raad van Boeton's vorst. (Vgl. Tiele, Europeërs, VIII, bldz. 136, v.) Pieter Both ging gaarne op dit denkbeeld in, omdat de Bewindhebbers hem hadden gelast, „op den profijtelijke handel van zandelhout order te stellen." 
havenen ontrent ende op 't eylandt van Bouton gelegen, zonder dat men deselve daer over sall mogen molesteren offte ijets daervoor pretenderen, maer beloofft den Koninck op deselve plaetse des noodigh zijnde alle hulpe ende bystandt ende dat ter consideratie dat de Hollanders dit guarnisoen tot zynder bescherminge onderhouden.

Ten vierde om den welstandt ende voordeell van beyde de natie op het profytelyckste te bevorderen, soo beloofft Zijne May ${ }^{t}$ van nu voortaan alle zijne onderdanen rijs te doen zaijen, all soo daer insonderh $^{t}$ veell aen gelegen is om de Moluccos tot welstandt te brengen.

Ten vijffden om alle eenigheijt ende vrundschap te onderhouden als ook om confusien te schouwen, beloofft den Koninck ende laet mits desen toe dat de soldaten, offte alsulcke persoonen die van wegen de Hollanders in dit coninckrijck zouden mogen blijven, zullen mogen hylycken met vrije vrouwen offte doghteren van zijn kouinckrijck, welcke niet zall belett worden het Christen gelooff aen te nemen; mede dat die Hollanders hier nevens andere des Konings onderdanen sullen vermogen slaven offte slavinnen te kopen. Eenige slaven van den Koninck offte sijne onderzaten bij de Hollanders komende, zullen deselve gehouden wesen wederomme te geven offte met den eygenaer te accorderen en zoo eenige slaven van de Hollanders, weghgelopen zijnde, door de Boutonders wederomme gebraght worden, zall daervoor ijdermaell gegeven worden naer advenandt dat zij kossten, te weten van 20 tanetten ${ }^{1} 2$ ende van 10: een. Van gelycken sallen de Boutonders, soo eenige van haere weghgeloopen slaven door de Hollanders wedergebraght worden.

Ten sesden soo beloofft den Koninck aen die van Banda schrifftelijk te ontbieden, hoe dat [met] de Hollanders eeuwigh contract ende verbondt gemaeckt heefft, deselve Bandanesen mede tot een vaste vrede ende verbondt vermanende ende jngevalle deselve Bandanesen tegen de Hollanders quamen te oorloogen, zal den Koninck zijn broeder met alle zijn onderdanen, die hij op Banda heefft, 't huijs 't ontbieden ${ }^{2}$.

Alle de voorverhaellde articulen belooven de Hollands mitsgaders

1 "Seeckere cleeden die daer (op Boeton) vaellen gheheeten Tannettes; welcke in de Molucques ende andere hieromtrent ghelegen plaetsen zeer getrocken werden." Zij schenen op Boeton in plaats van gereed geld gebruikt te worden (Apollonius Scotte, 1613, bij Tiele, Bouwstoffen, I, bldz. 12, 13).

2 Vooral deze bepaling van het contract werd door Scotte van gewicht gerekend. (Tiele, Bouwstoffen, I, bldz. 13). 
den grootmaghtigen koninck van Bouton ende zijne geallieerde vrinden ende vassalen te onderhouden ende doen onderhouden, waertoe zij haer mits desen verbinden tot een eeuwige vrindschap, conversatie en commersie ende dat zij elck anderen zullen geven t'allen tijde alle hullpe, faveur ende bijstandt naer vermogen elcx een tegen des anders vijanden, hetwelcke in aller voegen de Hollanders als oock Zijne $\mathrm{May}^{\mathrm{t}}$ mett zijne vassalen sullen verbonden blijven te onderhouden ende defenderen. 't Selve boven verhaelt is onder verbintenisse van getrouwight ${ }^{t}$, eere ende woordt, die beijde Godt ende onsen even naesten schulldigh zijn. Aldus gedaen voor Bouton op de strandt den $5^{\text {en }}$ Januarij $1613^{1}$.

\section{MOLUKKEN.}

\section{Januari 1613. 2}

Gedurende zijn verblijf in de Molukken heeft Pieter Both óók met verschillende hoofden van het eiland Makian een contract gesloten. (Vgl. Tiele, Europeërs, VIII, bldz. 125.)

Op huijden den $6^{\text {e }}$ Januarij $^{3} \mathrm{~A}^{\circ} 1613$ sijn int fordt Mauritius + op Noffackia 5 op 't eylandt Mackiam ten overstaen van de sengage van Limatau, als gecom ${ }^{\text {de }}$ op dit eylandt van wegen d'hooghmogende koninck Kitchill Moulafar ${ }^{6}$, koninck van Ternaten ${ }^{7}$, vergaderdt den gestrenge manhaffte Pieter Both, gouvern ${ }^{\mathrm{r}}$ gener $^{\mathrm{l}}$ wegen d'Ede Mogende $\mathrm{H}^{\mathrm{ren}}$ Staten Gener ${ }^{\mathrm{l}}$ der vrije Vereenighde Nederlandsche provintiën, sijne Princelijcke Ex ${ }^{\text {tie }}$ Mauritius, prince van Orangien, grave van Nassouw, etca ende d' $\mathrm{H}^{\text {ren }}$ Bewinthebberen der Generale Vereenighde Oostjndische Compe ter eenre ende meest alle de sengages ende de principale van het geheele eylaudt Makjan ter andere zijde ende hebben aldaer in forme van accoordt geraemdt ende besloten, dat voortaen ijder malcanderen zullen laten vrij ende liber in haer gelooff, sonder den anderen daerin te jncommoderen

1 Het contract is nog in hetzelfde jaar door Both "geconfirmeert". (Tiele, Bouwstoffen, I, bldz. 34). Zie hierna, contract 29 Augustus 1613.

2 Uit het Contractboek.

s Valentijn, I, b, bldz. 224, stelt den datum op 16 Januari 1613.

4 In 1608 had Paulus van Caerden het eiland Makian voor de O. I. C. in bezit genomen en dáár een fort met garnizoen voorzien.

Ngofakiaha.

6 Kaitjil Modafar.

7 Van ouds werd Makjan een onderhoorigheid van Ternate gerekend. 
ende jngevalle eenighe Mackjannesen quamen om van haer gelooff te veranderen, zullen van beijde zyden deselve wederom gegeven worden zonder haer int minste te mogen traghten respectivelijck Christen off Moors te maeken; voorder dat voortaan de wapenen, die alhier uijt Hollandt komen om onder de jnwoonderen voor coopmanschap verkoght te worden, voor de selffde prijs sullen genieten als die van de Ternaten ' sullen worden vercoght, die welcke zij belooven aen geene van onse vyanden te verkoopen.

Ende belooven oock de voorschreven sengagien ende principale uijt den name van de geheele gemeente, dat zij hunne nagelen aen geen andere uijtheemsche natie als alleen aen de dienaers van d'Vereenighde Comp ${ }^{\mathrm{e}}$ sullen verkoopen ende dat niet hooger als voor 50 $\mathrm{Ra}^{\mathrm{a}}$ van aghten de baer ad perpetuitatem, waer tegen de voornoemde $\mathrm{h}^{\mathrm{r}}$ Pieter Both uijt craghte van zijne commissie in den name van de voorschreven Comp ${ }^{\mathrm{e}}$ beloofft de voorschreven prijs tot geender tijt te sullen zoeken te verkleijnen.

Toucherende andere poincten, die als nu niet well en konnen werden geraemt, refereren haer beyde de partijen op 't geene dat in Maleije ${ }^{2}$ metten koninck van Ternaten ende zijnen adell sall worden verhandelt. ${ }^{3}$

Jngevalle eenige Mooren bij de onse alhier werden verovert, sullen wij gehouden wesen deselve aen haer te presenteren om te koopen, het welcke zij van gelycken aen ons sullen moeten doen, soo eenige Christenen in haer handen quamen te vervallen.

Ende omme onse begonnen vrindschap bondiger en vasster te maken, soo hebben de voorschreven sengagiën ende oversten uytten name van de geheele gemeente met solemnelen eede beloofft ende swooren, belooven ende zweeren mits dese, de gemelde mogende $\mathrm{H}^{\mathrm{ren}}$ Staten, Zijne princelijcke $\mathrm{Ex}^{\text {tie }}$ ende de Vereenighde Oostindische Compe alsmede de mogende koninck ende croone van Ternaten in alles gehou ende getrouw te zijn, met hunne vyanden buijten haeren weten int minste niet te tracteren, hetgeene tot prejuditie van de voorschreven prince ende koninck zoude mogen strecken, maer met de Hollanders ende Ternatanen des noodigh zijnde te leven ende sterven.

Waertegens de voornoemde $\mathrm{H}^{\text {re }}$ Pieter Both uijtten name van de voorschreven $\mathrm{H}^{\text {ren }}$ Staten beloofft ende geswooren heefft, beloofft

\footnotetext{
1 Valentijn : "als die aan andere Ternataanen".

${ }^{2}$ Malajoe.

$3 \mathrm{Vgl}$. hierna, contract $\mathrm{n}^{\circ}$ XLVI.
} 
ende zweerdt mits desen, de voorschreven Makjannesen tegen onse, der Ternatanen ende hare gemeene vijanden met alle mogelijcke maght tot de uytterste droppell bloets te assisteren ende helpen, ende metten vyandt int minste niet buyten haere weten tot hunne prejuditie te tracteren. Alles sonder arg ende list. In kennisse der waerheyt zijn hiervan gemaeckt twee alleens luydende contracten in Duytsch geschreven, als mede twee gelycke by haer in Tarnataens ${ }^{1}$ gecoucheerdt ${ }^{2}$, alle vier beij de voorschreven partijen onderteykendt, daervan elck een jnt Duytsch ende een in Ternataens gegeven is.

Actum utsupra. Onderstondt Pieter Both ende opgedruckt met des Comps zeegell in rooden wasse.

\section{MOLUKKEN.}

4 Maart 1613. ${ }^{3}$

Oók dit contract is door Both gesloten tijdens zijn verblijf in de Molukken (Tiele, Europeërs, VIII, bldz. 125, v en noot 1 van bldz 126.) De bedoeling was vooral de moeilijkheden te voorkomen, welke men vreesde van wederzijdsche propaganda op het gebied van den godsdienst. (Zie noot 1 op bldz. 111.)

Articulen ende voorwaerden gemaeckt ende beslooten tusschen den hooge mogende koninck Moulafar ${ }^{4}$, koninck van Ternaten, den prince Sedang ${ }^{5}$, zynen broeder ende alle de Ternataensche Raedt ter eenre ende Pieter Both, gouvern ${ }^{r}$ gener $^{1}$ over alle de fortressen, schepen, jachten ende personen jn de Oostjndiens van wegen $d^{\prime} E d^{\text {en }}$ Mogende $\mathrm{H}^{\text {ren }}$ Staten Gener ${ }^{l}$ der vrije Vereenigde Nederlandsche Comp ${ }^{\mathrm{e}}$, Sijn Princelijcke Ex ${ }^{\text {tie }}$ Mauritius, gebooren prince van Orangien, grave van Nassou etc ${ }^{\mathrm{a}}$. ende de $\mathrm{H}^{\text {ren }}$ Bewinthebberen der Gene-

1 Het verwijt, dat de Nederlanders soms aan de inlandsche autoriteiten contracten lieten teekenen, welke deze niet begrepen, gaat natuurlijk in elk geval niet op, waar (zooals meestal) de contracten óók in de inlandsche talen werden opgemaakt. Duytsch $=$ Nederlandsch.

2 Opgemakt, ingeschreven.

3 Uit het Contractboek.

4 Sultan Modafar.

5 Tiele, t. a. p., noemt hen Sidang. 
rale Comp ${ }^{\text {e }}$ ter andere zyden om alle swarigheyt te verhoeden, die ons van wegen het verschill jn de religie zoude mogen overkomen. ${ }^{1}$

Jngevalle daer eenige Ternatanen offte hunne slaven alhier op Ternaten bij de Hollanders komen onder pretext van Christenen onder ons te worden, sullen de voornoemde Hollanders gehouden zijn dadelijck in hunne handen weder te leveren ende in geender maniere deselve mogen versteken.

Daertegens wedercomme de voorschreven Ternatanen alle die van ons bij haer sullen overcomen, hetzij Hollanders off andere Christenen, datelijck sullen restitueren ende niet vermogen deselve te versteeken.

Soo wanneer eenige ondersaten van den coninck van Ternaten bij de Castilianers overgeloopen offte andersints vervallen ende aldaer Christenen geworden zijn, het zij bij wie van beyde de natiën zij zouden mogen komen, sal men deselve in presentie van den Koninck offte eenige van zijnen Raedt ende de Hollantsche overigheijt van die plaetse doen komen ende haer affvragen, tot welcke van beyde de religiën zij genegen zyn ende haer daerinne haer vrije wille laten gebruycken; dogh sullen de Hollanders deselve ondersaten Ternatanen, ${ }^{2}$ die allsoo bij ons overkomen, alhier van Ternaten op eenige andere plaetse moeten brengen, daer zij-uijt haer ${ }^{3}$ oogen zijn om alle zwarigheden voor te komen.

Jngevalle het eenige overgeloopene offte gevangene slaven souden zijn die bij een van onse beijde natiën hun quamen begeven, sullen deselve voer houden als boven, dogh den eygenaer de waerdije van die betalen.

De overlopers by een van onse beyden komende, zynde geen ondersaten van onse beyde natiën, sullen haer begeven mogen bij alsulcke religie als daer zij proffessie van doen.

Wanneer daer eenige Christenen door de Ternatanen in den oorlogh weder 4 bekomen, zullen gehouden zijn deselffde niet te verduysteren; maer ons ${ }^{5}$ te presenteren voor de waerdije van een

1 Dit vooral was een struikelblok in de verhoudingen tusschen verschillende streken van de Molukken en de Spanjaarden. Ook in het hieraan voorafgaande contract met Makian van Januari 1613 wordt dit punt zeer uitdrukkelijk geregeld. (Vgl. Tiele, Europeërs, VIII, bldz. 125, v.)

${ }^{2}$ Valentijn, I, b, bldz. 245, heeft „onderzaten der Ternataanen."

3 Nl. der Ternatanen.

"Valentijn : „worden”.

5 De Nederlanders. 
slaeff te lossen ende jngevalle wij hetselffde niet begeerden te doen, zullen zij daermede haer vrije wille mogen doen.

Daertegens de Hollanders van gelijcken alsulcke Ternataense Moren, als hier in onse handen jn den oorlogh sullen vervallen, gehouden sullen zijn aen de Ternatanen te presenteeren ende volgen den voet in het voorgaende artykell voorgeslagen.

Jngevalle eenige van onse gevangene soldaten door de Ternatanen op eenige toghten uyt des vyandts handen gekregen wierden, zullen zij gehouden zijn, deselffde bij ons liber ende vrij te laten komen, sonder daervan yets te pretenderen; van onser zijde desgelijcx.

Alle welcke artyculen zij luyden van wederzijde beloofft het ' ende belooven mits desen, getrouwelijck naer te komen ende volbrengen sonder argh offte list. In kennisse der waerheydt zijn hier van twee alleensluydende contracten in Duyts geschreven ende twee gelycke bij haer in Ternataens overgeset; alle vier bij henluyden onderteykent, daervan elcx een int Duyts ende Ternataens heefft. Aldus gedaen jnt fordt Orangie op 't eyland Ternaten de $4^{\mathrm{e}}$ Marty $\mathrm{A}^{\circ} 1613$. Was geteckendt Pieter Both.

\section{MOLUKKEN.}

8 Augustus 1613. 2

Both vertrok in Maart 1613 uit de Molukken. Bij Ambon gekomen, vond hij daar eenige Nederlandsche schepen. Hiermede versterkt, keerde hij naar de Molukken terug, om krachtiger tegen de Spanjaarden op te treden en inderdaad maakte hij het hun met behulp van den Tertataanschen sultan en verderen inlandschen aanhang lastig genoeg. Zóó zelfs, dat de Spaansche gouverneur, De Silva, om Tidore te kunnen behouden, de Spaansche bezetting van Saboegoe aan de Westkust van Halmaheira lichtte, de versterking, die, na kort in onze handen te zijn geweest, in 1611 door de Spanjaarden was genomen. (Zie hiervóór bldz. 93). Bij die gelegenheid was de Singadji uitgeweken en Both sloot thans dadelijk met dit hoofd een nieuw contract. Immers, het was voor den met ons bevrienden sultan van Ternate van groot gewicht en dus ook voor ons, dat Halmaheira voor hem en ons geopend bleef : hiermede hebben de Ternatanen haeren schuyr wederomme gecregen". (Vgl. Tiele, Europeërs, VIII, bldz. 127, 133-135; Tiele, Bouwstoffen, I, bldz. 32.)

Op huyden den $8^{\mathrm{e}}$ Augusty $\mathrm{A}^{\circ} 1613$ is bij den command $^{\mathrm{r}}$ Adriaen Block Maertsen ${ }^{3}$, als lasthebbende

1 Valentijn : "hebben".

${ }^{2}$ Uit het Contractboek.

3 Hij was door Both aangesteld tot chef van het garnizoentje van Saboegoe (Tiele, Bouwstoffen, I, bldz. 32). 
van de $\mathrm{E} . \mathrm{H}^{\mathrm{r}}$ Pieter Both, gouvern ${ }^{\mathrm{r}}$ gener van wegen $d^{\prime} E d^{e} \bullet$ Mogende $\mathrm{H}^{\mathrm{rn}}$ Staten van de Vereenighde Nederlanden, zijn Princelijcke Ex ${ }^{\text {tie }}$ Mauritius de Nassouw ende d'E. $\mathrm{H}^{\text {ren }}$ Bewinthebberen der Generale Oosstindische $\mathrm{Comp}^{\mathrm{e}}$, ter eenre ende den sengage van Sebouge ende zijne geallieerde ter andere zijde jnnegegaen en gemaeckt seker accoordt ende verbondt in manieren als volght.

Jn den eersten dat den sengage van Sabouge ende zyne gealliaerde gehouden sullen wesen, gelijck zij belooven mits desen, den koninck van Ternaten ${ }^{1}$ ende d' $\mathrm{H}^{\mathrm{r}}$ Gouvern ${ }^{\mathrm{r}}$ Generl, die van wegen d'Hooge Mogende $\mathrm{H}^{\text {ren }}$ Staten etca jn dese landen is offte die naemaels in sijne plaetse sal succederen ende gouverneren, gehouw en getrouw te blyven, aen de selve offte hare gecom ${ }^{\text {de }}$ alle gehoorsaemheyt ende goede diensten te bewyzen, goedt ende bloedt daer bij op te setten ende alles te doen, tgeene goede en getrouwe vassalen ende onderdanen ende beschermen heere ${ }^{2}$ schuldigh zijn.

Ende allsoo de Spangiaerden doer vreese van de komste der Hollanderen confuselijck hebben verlaten de stadt van Sabouge ende $t$ fordt gelegen op de strandt ende alles in ruyne gestelt is, js bij den voornoemde sengage ende zijn geallieerde beloofft, gelijck zij aennemen by desen gelegen[heyt], het fordt aen de strandt offte fordt aen de stadt, zulcx den voornoemde command ${ }^{r}$ sall goedt vinden, datelijck op te maken ende repareren volgens d'ordre die den Command $^{r}$ daertoe zall geven.

Twelcke gedaen zynde, beloofft den command $^{r}$ Adriaen Block Martense in qualite als boven, het gerepareerde fordt terstondt te voorsien met soldaten, geschut, ammonitie van oorloge, vivres en andere behoeften, omme alsoo den vyandt aff te keeren ende d'jnwoonders van dit landt te beschermen.

Voorder hebben de voornoemde sengage ende zijne geallieerde aengenomen ende beloofft, gelijck zy aennemen ende belooven by dese, dat se op de aenmaninge van den Gouvern ${ }^{\mathrm{r}}$ Generael offte zijne gecommitteerde sullen maken offte haere onderdanen doen maeken een off meer forten, van steen en kalck gemetselt, ende dat op soodanige plaetse, ook soo groodt ende in sulcker forme, als 't den $\mathrm{H}^{\mathrm{r}}$ Gouvern $^{\mathrm{r}}$ Generaell offte zyne gecom ${ }^{\mathrm{de}}$ tot haere meeste versekeringe sullen goedtvinden, behoudelijck dat den $\mathrm{H}^{\text {re }}$ Generl de

1 Vgl. hiervóór, bldz. 92.

2 "Aen hunnen beschermheere" of iets dergelijks.

7• Volgr. III. 
metselaers sall beschicken omme de forten te metselen, zonder eenige arbeyders meer in te stellen, maer zall voordts den arbeydt van alle materialen versorgen ende te brengen, komen ten lasste van de voornoemden sengagie ende sijne gealliaerde, die oock belooven dat, als wanneer die forten sullen gemaeckt wesen, deselve te sullen houden in reparatie, dack dight, met alle comodyteyten ten dienste van de soldaten voorsien ende onderhouden.

Sullende de voornoemde sengage eude syne geallieerde gehouden zijn, een bequame prauw te voorsien met volck ende aff te vaerdigen, soo dickmaells ende nae zoodanige plaetse als den officier vant fordt zall gelieven te ordonneren, t'welcke zyluyden beloofft te aghtervolgen.

Ende allsoo bevonden werdt, dat de onderdanen van den voornoemden sengagie ende zyne geallieerde hare sagu veell kleyner maeken dan zij in vorige tijden plegen te doen, hebben de voornoemde sengagie ende sijne geallieerde beloofft ende aennemen bij dese, dat ze op deze saecke ordre sullen stellen ende te weege. brengen, dat voortaen bij haere onderdanen de sagu gemaeckt zall worden zoo groodt alse in voortyden plagh te zyn, zonder dat noghtans de Hollanders ende haere geallieerde daer yets meer voor sullen betalen dan den ouden ende gewonelycke prijs.

Item sullen de Hollanders niet vermogen met de Spangiaerden offte hare adherenten te maeken een vrede, treves off stillstandt. van wapenen, offte zullen gehouden wesen, gelijck de voornoemde command $^{r}$ in qualité als voorschreven beloofft, dat de voornoemde sengage ende zijne geallieerde in soodanige vreede, trevis offte stillstandt van wapenen mede sullen zijn begrepen ende zoo den Spangiaerd evenwell met wapenen yets op den voorschreven sengage. ende zyne geallieerde op heure landen offte onderdanen willde attenteren, dat de Hollanders met hare maght sulcx sullen poogen te verhinderen.

Oock beloove de voornoemde sengage ende geallieerde, datse met: den Spangiaerden ende hare adherenten niet en zullen komen in eenigh bespreck offte onderhandelinge, zonder voorwetten, advys. en ordre van de Hollanderen, ook geen vivres aen haer verkoopen offte toevoeren, nogh dat se niet sullen gedogen, dat zulcx bij hare onderdanen geschiet.

Belooven voordts de contractanten elcx in den zynen te onderhouden ende doen onderhouden alle goede ordre eude dicipline, op dat tusschen de jnwoonderen van dese landen ende de Hollandsche: 
soldaten de vrundschap magh toenemen. Ende off gebeurde dat tusschen eenige soldaten ende jnwoonders eenige questie ende moeyten quame te rysen, sullen soodanige questieuse persoonen aen haren competenten reghter werden overgeleverdt, om naer behooren gestrafft te worden, sonder dat hier door offte andere particuliere onruste dit contract ende verbondt eenighsins magh verbroken offte jnt minste poinct magh geprejudyceerdt werden, maer belooven partyen elcx in zijne qualiteijt op haren eedt, trouwe en geloove, dit contract jnt geheell ende elck poinct jnt bysonder eeuwigh ende onverbrekelijck te onderhouden ende doen onderhouden. Aldus gedaen in de stadt van Sabouge te dage ende jaere als boven. Onderteyckent Adriaen Block Maertenszoon.

\section{BOETON.}

29 Augustus 1613. '

Den 3 Augustus 1613 vertrok Both weder van de Molukken met bestemming naar Bantam. Hij deed Boeton aan, waar hij den $22^{\circ}$ dier maand aankwam. De Compagnie's ambtenaren, welke hij daar had achtergelaten, hadden op ergerlijke wijze de beest gespeeld en Boetons vorst was "door dit onredelijek procederen uytermaten verstoort." Genoemde ambtenaren hadden „in perijckell gestelt niet alleen de nieuwe vruntschap metten Coninck gemaekt, maer oock alles wat daer is geweest." Both kwam gelukkig nog bij tijds, strafte de schuldigen zwaar en hernieuwde het contract met Boeton, 't welk nog met nieuwe bepalingen werd aangevuld. (Vgl. Tiele, Europeërs, VII, bldz. 136-140; Bouwstoffen, I, bldz. 33-35, 36-37.)

Approbatie op het contract met den koninck van Bouton.

Gesien het accoordt gemaekt op den $8^{\mathrm{n}}$ January ${ }^{2} \mathrm{~A}^{0} 1613$ tusschen den grootmaghtigen koninck van Bouton, sulltan ${ }^{3}$ Dayan Assianden, ter eenre ende capiteyn Appolonius Schotte, Raedt van Indien, van onsent wegen ter andere zijde, approbeeren en lauderen het zelve accoordt van poinct tot poinct te onderhouden, ende tot meerder verseekeringe van onse onderlinge vrundschap, soo hebben dese naervolgende artykelen daerbij geraemdt.

1 Uit het Contractboek.

2 De datum van dat contract is niet geheel zeker: 5 of 8 Januari.

3 Gewoonlijk wordt zijn titel als radja aangegeven. Zijn naam is in den tekst blijkbaar zeer verknoeid. Kan er de Boegineesche adellijke titel daëng in zitten? 
Alsoo den koninck voornoemt, out zynde ende genegen om naer zijne afflijvigheijt zijn landt in rust ende vreede te laten, heefft met ons advijs ende 't advijs van zyne princen ende raden mitsgaders de gemeente genomineerdt zyue legitime zoon genaemdt Shamerdyne ${ }^{1}$ die welcke den adell, raedt ende gemeente dadelijck hebben gesworen, naer 't overlijden van den voornoemden koninck voor koninck te erkennen ende te obedijeeren, welcke nomynatie ende electie ons zeer aengenaem is geweest, waeromme wij ondergeschreven beloove, naer afflijvigheijt van den presenten koninck, zijnen voorschreven zoon Shamerdijne voor koninck te erkemnen ende met deselve in alle vrundschap ende alliantie te continueeren, gelijck wij nu den jegenwoordigen koninck zijn doende.

Ende off gebeurde dat naer overlijden van den presente koninck eenigh geschill daerdoor quame te verrijsen, in zulcken kas veroblygeren wij ons zelven ende onse successeurs, den voornoemden Shamsadyne in alles te mainteneren ende assisteren tegen een ijder, die hun daertegens zoude willen approseren ${ }^{2}$ ende mede de andere zoonen, de princen ende ook andere princen ende ed ${ }^{\text {le }}$, niemandt uijtgesonderdt, te helpen, te mainteneren in hare gereghtigheyden ende jntercesseurs ${ }^{3}$, om alle querellen, die tusschen haer souden mogen rijsen, neder te leggen ende aen een yder sijn geregtigheydt voorstaen.

Ende allsoo voor ouse komste eenigh geschill geresen is belangende de vreemde natie, die allhier op de rheede gekomen zijn geweest, verklaren daeromme dat van nu voortaen alle vreemde natiën, geen uytgesondert, hier sullen vrij ende vranck mogen komen, geexcipieert den Spangiaerdt met de Portugesen ende hare adherenten, met dewelcke wij in openbare ${ }^{4}$

Ende allsoo dickwils gebeurdt, dat de vyandt haere goederen laden in joncken van Sorbaijen " ende Macassar, sullen de onsen met weten ende overstaen van de gecommitteerde van den Koninck die mogen visiteren; ende offt gebeurde, dat men daer eenige vijanden goederen jn vonde, sullen die verbeurdt wesen, d'eene helfft voor den Koninck ende de andere helffte voor den prince van Hollandt, als mede alle fergatten offte joncken de vijanden toebehoorende, hier komende.

1 Of Thamerdyne.

2 Sic!

3 Intercedeeren of zoo iets.

"Hier is iets weggevallen: „oorlog zijn" of iets dergelijks.

5 Soerabaja. 
Ende offt gebeurde dat hier omtrent deze eylanden eenige fergatten offte joncken van den vyandt quamen, jn sulcken cas zall den Koninck eenige correcorren toerusten, om die met assistentie van de onse te veroveren en prorato geparteert werde als vooren verhaelt. Dit gedurende soo lange wij met de Spangiaerden ende Portugesen met haer adherenten in openbaer oorlogh zijn en langer niet.

Item offt gebeurde dat daer eenigh geschill tusschen de onderzaten van den Koningh ende den onsen quam te rijsen, offte van wederzijden malcander ongelijck deeden, zall de questie bij den Koninck ende den Koopman ${ }^{1}$ nedergeleijt worden en een yder den zijnen naer verdienste straffen, zonder dat daeromme de gemaecte alliantie eenighsints sall worden gebrooken ende zoo sulcx niet en kan geschieden, sullent dan dadelijck den gouvern ${ }^{\mathrm{r}}$ van de Molucces adviseeren, omme de saeken te remedieeren ende verdragen.

Item den Koninck zall van alle fergatten offte ander schep gevaerdt, ${ }^{2}$ geen uijtgesondert, den toll naer ouder gewoonte alleen genieten, zonder dat van onsent wegen daer ijets op gepretendeert zall worden.

Aldus gedaen op $t$ eijlandt Bouton desen 29e Augusty $A^{\circ} 1613$ ende was onderteyckent Pieter Both.

\section{IJAKATRA.}

21 December 1614. ${ }^{3}$

Om verschillen te voorkomen omtrent de tollen, te Djakatra door de onzen te betalen, werd onderstaand contract door den GG. Gerard Reynst met Djakatra gesloten. (Vgl. Van der Chijs, Jakatra, bldz. 15-16; De Jonge, Opkomst, IV, bldz. XX.)

Appendix tot het contract met deu $\mathrm{ko}^{\mathrm{k}}$ van Jacatra gemaeckt.

Voordt omme aff te maeken de pretensen van tollen, die Zijne May ${ }^{\mathrm{t}}$ van Jacatra susstineert, hem te competeren over den arrack ende andere waeren, die alhier tot Jaccatra worden gekoght off van andere quartieren gebracht, is geaccord ${ }^{t}$ tusschen den $\mathrm{H}^{\mathrm{r}}$

1 Nl. de vertegenwoordiger der O. I. C.

2 Schepvaartuig?

s Uit het Contractboek. - Van der Chijs, Jakatra, bldz. 206, geeft „een oud afschrift op de Secretarie te Batavia berustende." 
gener ${ }^{l}$ Reynst ende den Sabandar uijt den name van Syne May ${ }^{\mathrm{t}}$, dat Zijn May ${ }^{\mathrm{t}}$ voornoemt daervoor van de Hollanders jaerlycx zall ontvangen ende genieten $800 \mathrm{R}^{a}$ van aghten '. Dies sullen de voorschreven Hollanders vrij zijn van vordere tollen, jmpositiën ende andere swarigheden, hoedanich die oock zouden mogen zijn, over den arack, rys, boonen, Chineese ende andere waren ende coopmanschappen, die hier zouden mogen gekoght worden; oock vryelijck alhier mogen laden alle schepen komende uijt het vaderlandt, van de cust van Cormandell, Atchin, Johoor, Patane ende de eylanden van Moluccos, Banda, Amboyna, Solor ende andere quartieren van Jndien, geen uijtgesondert, sonder van de waren, die zij uijt de voorschreven quartieren zouden mogen brengen ende alhier lossen ende wederladen offte verkoopen, eenige tollen offte lassten en andere swarigheden te betaelen, hoedanigh die oock zouden mogen geimagineerdt worden, uytgesondert de specerijen ende het sandelhoudt, dat de Hollanders alhier tot Jaccatra souden mogen kopen, daer vooren de voorschreven Hollanders betalen sullen 5 ten 100 , als hiervooren int contract begrepen staet, well verstaande dat den koninck van Jaccatra voorschreven t'geene vooren verhaelt is sall aggreeren.

Aldus gedaen in de logie tot Jaccatra ter presentie van anaghoda ${ }^{2}$ Wattingh, Chineesch, op den 21 ${ }^{\mathrm{e}}$ Xber. 1614.

Ende omme voor te komen peryckell van brandt, zal Zijn May ${ }^{t}$ aff doen breken all de huijsen int Chineese quartier, die ontrent de logie staen, tot $\mathrm{t}$ rivierken toe en niet gedoogen datter van ymandt eenige bout ${ }^{3}$ werden, ten ware van steen van 't onderste ten dack toe jncluijs ${ }^{+}$. Was geteeckent G. Reijnst.

Ik laat hier tevens volgen Herbert de Jager's verkorte vertaling van den Maleischen tekst van bovenstaand contract.

1 Aan den kant staat hierbij aangeteekend: „Heefft den Koninck versoght, dat dit selve contract soude luijden in te gaen van de $800 \mathrm{R}^{\mathrm{n}}$ jaerlijeks te betalen prymo Januarij 1615. De maent wort bij haer genoemt boulanhadgy" (Dzu'l hidjah).

2 Nachoda $=$ schipper, scheepskapitein.

s "Gebout" bij Van der Chijs, bldz. 207.

4 Deze clausule komt niet voor in achterstaande vertaling uit het Maleisch. Vgl. van der Chijs, bldz. 15, v. 
Translaet uijt het Maleijts van het voorschreven appendicx tot het contract met den $\mathrm{ko}^{\mathrm{k}}$ van Ziajacarata nu gemaeckt; bij den onderkoopman Herberdt de Jager overgeset.

Loff sij Gode, heere der creaturen.

Dit is het accoordt van den pangiran Ziacarata, wesende kiay siagbandar ${ }^{1}$ volmaghtight, omme met den generl Reynst te contracteren en hebben zij geaccordeerdt s'jaerlijex aght honderd $\mathrm{R}^{\mathrm{a}}$ aen den Pangiran te geven en niet meer en werdt daerbij beloofft, de jmpositien op den arack en de roba roeba van de schepen aff te schaffen en jndien zij eenige Chineese waeren moghte komen te kopen en rijs, catsiangh, ${ }^{2}$ en sal men van geen toll mogen spreeken maer men sall moeten betalen toll voor den jncoop van pepér alhier, als ook nagelen, nooten en foelje en sandelhout en sal men voor hondert $\mathrm{R}^{\mathrm{n}}$ vijff $\mathrm{R}^{\mathrm{n}}$ moeten geven. En soo se coopmanschappen aenbrengen, zoo zullen ze die hier mogen ontlaeden en aen landt brengen, zonder dat men ergens van ijet sall mogen pretenderen. En alldus is den Capiteijn Moor ${ }^{3}$ met den pangiran van Ziajakarata veraccordeert.

\section{SOLOR- EN TIMORGROEP.}

15 Maart 1616. ${ }^{4}$

Apollonius Scotte had in April 1613 het Portugeesche fort (Henricus) op Solor veroverd. (Vgl. hierachter het contract van 7 September 1618). Tijdens de belegering van deze versterking had hij betrekkingen aangeknoopt en contracten gesloten met verschillende "Coningen" 5 op Timor, o. a. met dien van Amanoebang aan de Zuidkust, betrekkingen die in de eerste jaren werden onderhouden. (Tiele, Europeërs, VIII, bldz. 137-139; Bouwstoffen, I, bldz. 15, v., 20, 91, 92, 101). Al spoedig (1615) kwamen er oneenigheden (Zie bldz. 120, noot 2). Om deze uit den weg te ruimen, sloot Crijn van Raemburch, welke de Compagnie toen op Solor, Timor en omliggende eilanden vertegenwoordigde (Tiele, Bouwstoffen, I, bldz. 101) een contract met dit inlandsch hoofd.

1 Kiahi sjahbandar.

${ }^{2}$ Katjang $=$ boontjes.

${ }^{3}$ Capitão mór: een door de inlanders uit het Portugeesch overgenomen titel óók voor onzen GG.

${ }^{4}$ Uit het Contractboek.

5 Met den titel radja, enz. 
Contract gemaeckt met den $\mathrm{ko}^{\mathrm{k}}$ van Amanaban aen de zuijdtzijde van Tymor.

Op huyden den $15^{\mathrm{e}}$ Marty 1616 is met den koninck van Amaban ${ }^{1}$ door Crijn van Ramburg, coopman van wegen de Vereenigde Oost-indische Comp ${ }^{\mathrm{e}}$, gecontracteerdt ende met eede bevestight tgeene volght.

Eerst dat de fauldt bij den Koninck voorleede jaere begaen ${ }^{2}$ ende allsnu weder bij hem geremedieert, daermede zullen zijn doodt ende niet ende dat men met den zelven weder zullen wezen vrunden als van te vooren.

Vorder dat men hier weder zullen komen handelen, zoo wanneer den Koninck zall verklaren zandelhoudt te kunnen leveren, tzij over een, twee offte drie jaeren. Tot welcken eijnde men hier s'jaerlijcx enpassant zullen aenkomen om te vernemen, wanneer hier handelinge vallt.

Den Koninck zall gehouden wesen, zoo wanneer men hier handelt, te leveren een perck van sandelhoudt van 5 vadem ende twee voeten lanck, een ende een halve vadem hoogh ende drie en twee derde vadem breedt, alles volgende de mate met een coorde daer affgenomen ${ }^{3}$, daer van den Koninck ook diergelycke heefft behouden, mits dat hem daer en tegen gegeven zall worden allsulke zijrij pinangh, roube roubes, louge batte bantell tyckell ende batatulo dialandt ${ }^{+}$als van desen jn de eerste handelinge metten Koninck is geaccordeerdt. 5

Alsnogh zall, boven't geene voorschreven is, aen den Koninck

1 Amanoebang.

2 Uit eene onuitgegeven resolutie van President en Raad te Bantam van 9 September 1615 (Rijks-Archief) blijkt, dat de radja van Amanoebang slechts de helft van het sandelhout had geleverd, dat hij aan de O. I. C. had beloofd „en bovendien den onzen grooten affront en moeite aangedaan." Aan Van Raemburch werd toen, op zijn eigen voorstel, last gegeven, den radja „binnen scheeps boort, doenlyck synde, geapprehendeert" te dwingen, "syne belofte... metten intrest van dien te voldoen, gelyck by de Portugesen voor desen in gelycke gevallen gepleecht is."

3 Een vaste maat werd dus aangenomen.

4 Het zijn benamingen voor tollen of voor doeleinden, waarvoor de tollen door den Radja werden geheven. (Vgl. Bouwstoffen, I, bldz. 1). De bedoeling, van "sirih pinang is duidelijk" : een belasting, om zich dit genotmiddel te verschaffen. (Vgl. Encyclopaedie, III, bldz. 264, 614). - Roeba roeba is reeds verklaard.

${ }^{5}$ In het contract van 1613 (1618), dat tot ons is gekomen, is van Amanoebang geen sprake. Er zal dus een ander contract met hem zijn gesloten. 
voor zijne mandorijns ${ }^{1}$ gegeven worden om onder haer uijttedeelen, voor hare mavoe doeves ende hoofft te binden dit navolgende:

7 dragams

10 hallve armosijnen ${ }^{2}$

10 canges van twee vadem

27 parrangs. ${ }^{3}$

Men zall niet gehouden wezen, aen den Koninck eenige louge batte te geven, voor ende aleer 't voorschreven besteck volcomentlijck volgeleverdt zall zijn, maer zijn zijrij pijnangh, roube roubes, t'ander $t^{\prime}{ }^{+}$voordt begin van de handelingen al naer cosstuijme.

Die geene die hier komt handelen, zall niet gehouden zijn in eenige schenkagie aen den Koninck offte andere, dan als hij vrijwilligh begeerdt, te geven.

Den Koninck zall niet vermogen, gelijck als hij ook bij desen beloofft, met eenige natie anders als d'Hollanders te negotieren ende zooveell mogelijck is alle vremden uijt zijn landen te weeren ende geen handelinge toe te laeten.

Ende jngevalle eenige moghte komen, dat hy zulcx in der yll aen de onse ter plaetse zij op de kust van Tijmor zijn, zall adverteren, op dat als dan by haer daerin vorder allsulcke ordre magh werden gestelt, om soodanige te aghterhalen als geraden gevonden zall worden.

Is mede aen den Koninck toegeseijt, bij alldien hij eenige parangs moght van doen hebben, om sijn landt mede te bouwen, all eer hy handelinge zall konnen verleenen, dat men hem 5: a: 600 zullen voorschieten, mits dat deselve in tijde van negotie aen zijn roube gekordt sullen werden.

Alldus gedaen jnt jaght de Sterre, leggende ter rheede voor Amanaban jn Tymor, ten dage ende jaere als boven.

1 Ook elders in den Maleischen Archipel wordt deze titel aan aanzienlijke inlandsche ambtenaren toegekend. Vgl. de bewijsplaatsen bij Hobson-Jobson, p. 420-22, die de afleiding van Skr. mantri (Maleisch manteri of mantri) aannemelijk moeten maken.

2 Een soort zijden stof.

3 Hakmessen, houwers.

4 En het andere? 


\section{BANDA.}

3 Mei 1616. 1

Na het contract van 10 Augustus 1609 waren de vijandelijkheden tusschen de Nederlanders en de Bandaneezen - zij het dan ook met korte tusschenpoozen van schijnvrede - blijven voortgaan. De monopoliestaatkunde der Compagnie was gehaat bij de Bandaneezen en de O. I. C. zette die door tot het bitter einde. De verwikkelingen werden verscherpt door de pogingen der Engelschen, om deel in den handel te krijgen, terwijl godsdiensthaat (Islam contra Christendom) mede zijn invloed deed gelden. In dezen strijd is de verovering van Poeloe Ai door Jan Dirkszoon Lam in April 1616 van belang geweest. Zij leidde tot een vredesverdrag, belichaamd in onderstaand contract. (Vgl. Tiele, Europeërs, VШ, bldz. 168-169; VIII, bldz. 120, v., 127, 147-149, 176-179; Van der Chijs, Banda-eilanden, bldz. 52-87).

Contract gemaeckt bij den $\mathrm{H}^{\text {re }}$ Jan Dirckzoon Lam, Raedt van Indie ende command ${ }^{r}$ over de vloote schepen, mitsgds de presente Raden van wegen d'Hooge Mogende Heeren Staten Gener', Zijn Ex tie ende d'He Bewinthebberen der Vereenighde Oostindische Compe ter eenre ende de orangcays offte principale ende andere inwoonderen van de eylanden van Bandanera, Pouloäy, Poulo Ron ende Rossingeyn ter andere zijde.

Eerstelijck belooven ende zweeren wij, boven geschreven oranghcays ende andere inwoonderen van Banda, op onsen bouck, metten bovengenoemde Hollanders ende hare onderdanen, t zij swart offte witte natie, van nu aff aen jn een eeuwigen ende vassten peijs te leven ende te handelen op dese naervolgende artykelen.

D. E. voorschreven principale en andere jnwoonderen jn de eylanden van Banda sullen desisteren van alle actie en pretensie, die zijluijden op de eylanden Nera ende Poulo Ay gehadt hebben ende nogh menen te hebben ende gedoogen, dat de selve bij de voorschreven Hollanders geregeerdt ende gepleubeerdt werden; alsoo de voorschreven eylanden bij de voorschreven Hollanders in een reghtvaerdige oorlooge metten sweerde geconquesteerdt zijn.

Sullen de voorschreven Bandaneesen geene van de voorschreven Hollandse overloopers in eenige van de voorschreven eylanden plaetse off residentie te geven met belofften, zoo wanneer bij de voorschreven Hollanders contrarie bevonden werdt ende eenige derselver overlopers in de voorschreven eylanden werden gesien offte vernomen,

1 Uit het Contractboek. 
dat zy deselve in de Hollanders handen sullen leveren, omme bij deselve daermede gedaen te werden, sulcx als zij luyden geraden sullen vinden.

Ingevalle het nu naer dese quame te gebeuren, dat ymant van de Hollanders aen der Bandaneesen zyde quame overteloopen, die haer lieden gelooff willde aennemen, soo sullen zyluyden gehouden wesen, deselve datelijck aen den gouvern ${ }^{r}$ van 't cassteell Nassouw op Neyra offte ymandt anders t'zynen t'wegen over te leveren, zonder deselve te besnijden offte Moors te maeken, gelijck de Hollanders ter andere zyde belooven te doen.

Alle specerijen, die in voorschreven eylanden komen te vallen, sullen aen niemandt als aen de gecommitteerde van de $\mathrm{H}^{\text {ren }}$ Staten, Zijn Exelentie ende de $\mathrm{H}^{\text {ren }}$ Bewinthebberen mogen verkoopen, verhandelen ofte verruijlen, offte gedoogen, dat se bij eenige van haer onderdanen verkoght, verhandelt offte verruylt worden: hier onder verstaet men begrepen te zyn Engellschen, Franssen, Javane, Maleijen, Macassaren, Boutonnesen ende andere Europische ende Zwarte natien, hoedanigh deselve souden mogen zijn. Ende bij alldien bevonden wordt, dat bij ymandt anders als de Hollanders jndirectelijck en door sinisstre middelen eenige speceryen moghten gecoght offte bekomen zijn, soo sullen de voorschreven Bandaneesen gehouden zijn, ons de restitutie von soodanige verkoghte specerien te helpen vervorderen, t'zij met gewelt offte andersints, sulcx als de gelegenh ${ }^{t}$ mede sal brengen.

De schepen, jachten, joncken off eenigh ander vaertuijgh, dat van eenighe der voorschreven natien voor eenige der voorschreven eylanden souden willen anckeren, sullen de voorschreven Bandaneesen geen ancker grondt leenen, maer gedoogen dat deselve met geweldt offte andersindts by de voorschreven Hollanders van daer gehaeldt worden, te waere zij alreede het ancker hadden laten vallen ende op t'landt gehaeldt waeren, uijtgesondert die van Bantam, Jacatra offte Japara, dewelcke nae dat se bij de Hollanders gevisiteerdt zijn ende van deselve paspoordt hebben, voor Lonter offte Selamme alleenlijck sullen mogen anckeren.

Oock en sullen de voorschreven Bandaneesen van de voorschreven eylanden niet vermogen, met eenigh vaertuijgh, hoedanigh hetselve soude mogen zijn, sonder voorweten van $d^{\prime} H^{\text {re Gouvern }}{ }^{r}$ offte ymandt van sijnent wegen van 't landt vertrecken, veell minder eenige specerijen vervoeren, maer sullen gedoogen, $t$ selve vaertuygh bij de Hollanders gevisiteerdt werde; ende jngevalle eenige Bandaneesen oftte ymandt van harentwegen sonder paspoordt by de 
voorschreven Hollanders in zee aghterhaelt wordt, dat deselve met alle hare ladinge aengehaeldt ende voor eenen vrybuijt verklaerdt sullen werden.

D' voorschreven jnwoonderen sullen mede gedoogen, der Hollanders schepen offte jaghten t'allen tijde haer waer op Comber sullen mogen halen ende den steen die aldaer is leggende tot fordt Nassouw mogen gebruycken zonder daervoor int minsste yets te betalen.

Besonderlijck oock, dat de Bandaneesen niet en sullen vermogen, op d'eylanden Nera, Pouloaij voorschreven te komen.met eenige wapenen als eenlijck een parangh ende cris, op verbeurte van de voorschreven wapenen, sulcx als die souden mogen syn, ende den persoon daer die selve bij bevonden souden mogen werden.

Ende sullen mede niet vermogen, de sagouw ende rietboonen op 't eylandt Poulou Ay eenighsints te beschadigen, veell min van 't landt vervoeren ende alleenlijck daervan soo veell gebruycken als tot het maecken van haere huysen soude mogen van doen hebben.

De voorschreven Bandaneesen van de voorschreven eylanden sullen gehouden wesen, yder Portugeese baer foilye aen de gecommitteerde van de voorschreven Hollanders te laeten volgen voor de waerdije van $100 \mathrm{R}^{\mathrm{n}}$ van $8^{\mathrm{e}}$ ende de nooten voor $10 \mathrm{R}^{\mathrm{n}}$ van aghten yder baer.

Alldus gedaen ende gecontracteerdt op 't eylandt .Neyra jnt fordt Nassouw in Banda desen $3^{\text {e }}$ Mey 1616 ende was onderteeckendt in Arabische letters bij den orangcays van Lontor, Elamme ', Pouloay, Poulo Ron, Rossingeyn, Labetacke, Ouwendeners ende Ortatten ende jn Nederduytse letteren beij de $\mathrm{H}^{\mathrm{re}}$ command $^{\mathrm{r}}$ Jan Dirckse Lam, Gysbertszoon van Vianen, Dirck Pieterszoon van de Sande, Adriaen van der Dussen, Phillips Sweerius, Willem Janszoon ende Willem Jacobszoon.

\section{DJAKATRA.}

8 0ctober 1616. ${ }^{2}$

De Nederlandsche factorij te Djakatra begon meer en meer van beteekenis te worden. Ook Jan Pieterszoon Coen, sedert deze in October 1613 de leiding had gekregen van de zaken der O. I. C. in Bantam en Djakatra, zag het belang van deze vestiging in. Vooral sedert 1616 begon het kantoor dáár in omvang toe te nemen. En tevens de zucht

1 Slaman of Celammon.

${ }^{2}$ Uit het Contractboek. 
der onzen, om daar een plaats in te nemen, die desnoods tegen aanvallen verdedigd zoude kunnen worden. Vandaar de moeite, die men doet - en blijkens onderstaand contract, met suces - om meer ruimte voor de factorij te verkrijgen. (Vgl. Van der Chijs, Jakatra, bldz. 19, 209). 1

Contract gemaeckt tusschen den koninck van Jacatra ter eenre en Jacob Breetvellt, ${ }^{2}$ opperkoopman van de logie aldaer, ter andere zijde.

Wegens sekere plaetse op de riviere, om een hoff alldaer bij ons te maeken, bij Sijne May ${ }^{\mathrm{t}}$ vergundt en geconsenteert: op conditien en voorwaerden dat de overigheden van de Holland ${ }^{\text {rs }}$ niet sullen vermogen, in voorschreven plaetse te laten komen veell volcx van bootgesellen en soldaten, nogh ook toelaten, daer arack gebraght werde om droncken te drinken, ${ }^{3}$ off ook eenige questie van ons tusschen de Javanen, die van de riviere op off ontrent den hoff vaeren en water halen, worde gemoveerdt, allsoo de Coninck verstaet, de reviere voor een yder bij zijne toelatinge vrij is. Maer eenige Javanen off andere zonder onse toelatinge binnen den pagger van den hoff secretelijck gecomen zijnde, vermogen ${ }^{4}$ die daer uijt te doen gaen off oock van dijverije beschuldigen. De Hollanders en sullen noyt vermogen, binnen den hoff eenige Javaense vrouwen te doen halen off komen om te boeleeren, allsoo 'tselve tegens hare costuyme is en voorschreven koninck sulcx niet begeerdt, opdat daerdoor geen quesstie off dissentie tusschen partijen worde gemoveerdt. Jngevalle contrarie dit accoordt worde gedaen, vermagh den Koninck voorschreven plaetse weder nae hem te nemen en besitten, als voor desen gedaen heefft.

Aldus gedaan in Jacatra ady $8^{\mathrm{e}} 8^{\text {ber }} 1616$.

\section{AMBON.}

16 November $1616 .^{5}$

In 1615 werd door den G.G. Reynst en den Raad van Indië besloten met het oog op de kosten, het garnizoentje te lichten, dat kort geleden was gelegd op Siauw, een der Sangi-eilanden. Men vreesde echter, dat

1 Wat De Jonge, Opkomst, IV, bldz. XLIII, nog omtrent dit contract mededeelt, heb ik nergens elders aangetroffen.

2 Van der Chijs, bldz. 209, heeft: Breekvelt.

3 Dit teekent!

${ }_{4}^{4}$ Nl. de Nederlanders.

5 Overgenomen uit Tiele, Bouwstoffen, I, 202, v. 
nu de Spanjaarden (met het oog op de gunstige ligging van het eiland tusschen de Philippijnen en de Molukken) met de bewoners daarvan weder betrekkingen zouden aanknoopen. Met het oog daarop en om de Banda-groep van meerdere bevolking te voorzien wilde men de bewoners van poeloe Siauw van dáár vervoeren. Dit vond plaats in October: Adriaan van der Dussen en Frederik Hamel hebben deze „odieuse lasten" volvoerd. De reis van Siauw naar Banda ging via Ambon: de gelichte inlanders kwamen daar in Februari 1616, ongeveer tegelijkertijd met een aantal bewoners van Solor (waar wij ons fort hadden verlaten), "al mede naer Banda gedestineert". Toen dit bekend werd, weigerden verschillende dorpen van Ambon, de gevorderde, en niet alle verschuldigde, heerendiensten voor de Compagnie te verrichten, „door dien sij vreese hadden, dat se mede mochten werden gevoert naer Banda". Bij de hierop gevolgde vijandelijkheden bleek, dat nog andere grieven bestonden, veelal gevolg van het onhandig en ruw bestuur van den gouverneur Adriaan Bloeq Martenszoon. Gelukkig kwam de humane, tactvolle Steven van der Haghen tussehen beide: op zijn last begonnen onderhandelingen en de geschillen werden beeindigd bij onderstaand "accoord". (Vgl. Tiele, Bouwstoffen, I, bldz. XVIII, v., 132-137, 196-203; Europeërs, VIII, bldz. 189-191).

Op huyden den $16^{\mathrm{n}}$ November $A^{\circ} 1616$ doort beroup van den heer Gouverneur Adriaen Block Martensz. dees onderges. personen vergadert zijnde is geresolueert als volght.

Alzoo door interessie van de Orangcays van Hyttoe, Mamalo ende Wackell, ' mițsgaders oock de Coningen, Oranghcays ende principaelen van onse eylanden, tegenwoordich alhier vergadert zijnde, het soo verre gebracht is, dat de rebellerende dorpen, gelegen int hooghe als Soya, Kilangh ende Ema ${ }^{2}$ met de cleyne dorpen daer onder ressorterende, hun genegen toonen om op de volgende artijculen wederomme als goede'onderdaenen bij den gouverneur ontvangen te werden, is goetgevonden hier mede geen meerder tijt te verslijten maer op de volgende conditien deese handelinge te besluyten.

Eerstelijck dat aen de zijde vanden gouverneur sullen blijven alsulcke slaven, als geduyrende de rebellye vercregen ofte genomen sijn, ende sal oock ongehouden sijn te vergoeden de schade die de bovengeschreven dorpen souden mogen bijden oorloch van den Gouverneurs zijde hebben geleeden.

Dat die van het dorp Amantello, ${ }^{3}$ welcke vant Casteel geloopen

1 Wakal aan de Noordkust van Hitoe.

2 Vergelijk voor de plaatsbepaling Tiele, Bouwstoffen, I, bldz. 196-202. Valentijn, II (Ambon), a, bldz. 118-119 en de kaart van "Amboina".

s Zie Valentijn, t. a. p., bldz. 118. 
ende op Soya hun geseth hebben, weder sullen comen woonen bij 't Casteel haer oude plaetse.

De voorsz. bovendorpen sullen wederomme treeden in het ordinaris wercken gelijckse deeden voor de rebellye.

Sullen mede moeten raseren ende affbreecken allen tgeene zij lieden tot sterckten ende thaerder defentie souden mogen opgeworpeu ende gemaeckt hebben, als mede openen ende reynigen alle wegen die gestopt ofte met voetangels beseth sijn.

Datse sullen betaelen voor een breucke ende om datse nu over de acht maenden geen quaert ${ }^{1}$ gehouden hebben, 720 patoolen ${ }^{2}$ ende noch 480 patoolen voor vier slaven bij hen lieden in de rebellye doot geslagen.

Ende belangende de 2 Hollanders doot geschoten inden tocht bij den Gouverneur gedaen op Soya, daer van is geseyt soo lichtelijck geen pardoen te willen geeven, maer datse daeromme versoeck sullen doen aen den heer Gouverneur generaal soo haest sijnne Ed. zal hier gecommen zijn, met toesegginghe daertoe onse hulpe te doen ende datse van Ed. moegen hier van een pardoen brief becommen. Aldus gedaen ende besloten int casteel Amboina datum vts.

Ende was onderteyckent:

\author{
Adriaense Block Martsz. \\ Steven Coteels. \\ Harman van Speult. \\ Jan Steur. \\ Aerts Gijsels. \\ Meijnert Pietersz., Secretaris.
}

\title{
LIV. BANDA.
}

\section{April 161\%. ${ }^{3}$}

Reeds spoedig na het verdrag van 3 Mei 1616 braken op de Banda-eilanden de vijandelijkheden weder uit. En zoolang de O. I. C. haar handelsstaatkunde, die alle welvaart en alle vrijheid der Bandaneezen buitensloot, zelfs hun bestaan in den letterlijken zin van het woord in gevaar bracht, volhield, kon dit niet anders. De autoriteiten der O. I. C. traden met alle macht, die zij in die streken konden ontwikkelen, op, vooral toen

1 Tiele, t. a. p., bld. 197, verklaart dit met: „Om beurten werken aan 't Kasteel". Vgl. Van Hoëvell, Ambonsch-Maleisch, bldz. 17, sub voce „kwartoe”.

2 Een zeker soort katoentjes: Hobson-Jobson, p. 520; Van Hoëvell, Ambonsch-Maleisch, bldz. 26.

3 Uit het Contractboek. 
de Engelschen juist in die dagen een stelling van eenige beteekenis op de Banda-eilanden gingen innemen. Een gedeelte der Bandaneezen (die van Groot Banda en Rosengain) benevens bewoners van Ai en Banda Neira, echter niet alle, nl. niet die van Roen, sloot in April 1617 weder vrede met den GG. Laurens Reael, die toen zelf bij die eilanden verscheen. (Vgl. Tiele, Europeërs, VIII, bldz. 192-198; Tiele, Bouvstoffen, I, bldz. XXIX-XXXI; De Jonge, Opkomst, IV, bldz. XXIX-XXXI; Van der Chijs, Banda-eilanden, bldz. 87-102 en 181, v.)

Accoordt gemaeckt bij Lourens Reael, gouvern ${ }^{\mathrm{r}}$ gener $^{\mathrm{l}}$ van wegen de Prins en de Staten van Hollandt, met de orancays van $t$ ' eijlandt Banda ${ }^{1}$ ende met elck dorp int besonder daer op gelegen, $t$ sampt die van $d^{\circ}$ t eylandt Rossingeyn ende die vant eylandt Neyra ende Pouloway, tegenwoordigh opt eylandt Banda en Rossingeijn woonaghtigh.

Eerstelijck belooven ende sweeren van beyde zyde den peijs eeuwelijek te onderhouden ende naer te komen alle de artykelen, begrepen int contract, voorleden jaer gemaeckt metten command ${ }^{r}$ Jan Dirckszoon Lam, uijtgenomen in soodanige gedeellten off artykelen als nu op nieuw is geaccordeerdt ende veranderdt worden, de welck wij sullen naerkomen in der vougen als hier naer zall worden beslooten.

Men sall van wederzyden niet meer gedaghtigh wesen eenige moeyte offte overlast voor desen, t'zij ten tijden van den oorloghe offte peys, malcanderen aengedaen, oock niet mogen vereijschen restitutie offte betalinge van 't geene voor deesen verlooren offte verniellt is, nogh ook relaxeringe van de gevangenen.

Ingevalle eenige Europische natie souden willen ankeren voor eenige plaetsen van de voorschreven eylanden Banda ende Rossingeijn ende sullen de inwoonderen sulcx niet toelaten; indient in hare maght niet en is sulcx te beletten, sullen terstont den gouvern ${ }^{\mathrm{r}}$ van 't fordt aendienen, maer voor allen sullen sij niet toelaeten, datter cenigh volck aen landt komen. Belangende de natie benedens wints gelegen offte eenige andere vremde coopluijden sall men sigh reguleeren naerdt geene voorleeden jaer gecontracteert is.

Soo lange den oorlooge tusschen die van Pouloron sall duyren, en sullen die van Banda ende Rossangeijn voornoemt naar Pouloron niet vermogen varen omme te handelen nooten, foeillie offte eenige andere waren; oock haer niet assisteeren met volck, ammonitie, vivres

1 Groot Banda. 
offte andersints, nogh oock gedoogen dat die van 't voorschreven ${ }^{1}$ eylanden Banda ende Rossingeijn komen.

Ende opdat die van Poulo Ron onder t dexell ende den naem van die Banda ende Rossangeyn ons geen overlast en doen, soo en sullen die van de voorschreven twee eylanden ende alle andere daerop woonaghtigh niet verder als Poulo Ay varen, dogh geen voet op 't eylandt setten als met schriftelijck verloff van den Gouvern ${ }^{\mathrm{r}}$. Jn welcken gevalle zij evenwell 't eylandt niet en sullen mogen aendoen dan reght voordt fordt ende die contrarie bevonden wordt te doen, sall voor vyandt aengerekendt worden.

Indien eenige van de voorschreven Bandaneesen met een jonke offte champan ${ }^{2}$ naer eenige andere plaetsen souden willen varen, sall niet sonder passepoordt van den Gouvern ${ }^{\mathrm{r}}$ mogen geschieden ende sall die gouvern ${ }^{r}$ vermogen soodanige joncken offte champans te visiteren.

Soo wanneer de Gouvern ${ }^{\mathrm{r}}$ op de voorschreven eylanden een man vijff offte zes sall willen stellen omme op alles toe te sien ende off het contract niet gevioleerdt en word, zullen de voorschreven Bandaneezen sulcx niet mogen weygeren.

Soo ymandt van de twee voorschreven eylanden komt op de eylanden Nera ende Poulo Ay, en sullen geen andere wapenen als een cris ende parangh mogen mede brengen ende bij alldien ymandt met andere op de voorschreven eylanden wordt bevonden, zall zijn op verbeurt van de wapenen ende persoon, daerby deselve bevonden worden.

Ingevalle den Gouvern ${ }^{\mathrm{r}}$ op Comber ymandt om water seijndt, zullen de voorschreven Bandaneesen sulcx moeten gedoogen zonder het selve te weijgeren.

Onder de Hollanders naem worden gerekent niet alleen die in Hollandt gebooren zijn, maer alle haerluijden volck ende onderzaten, t'zij datse zijn van Banda offte andere landen, vrije luijden offte slaven, gevangenen offte van selffs overgeloopen zonder onderscheydt.

De orangcays, leeden [ende] steeden van Banda ende Rossingeijn alsmede de uijtgewekene van Poulo Ay ende Nera, bij haer woonaghtigh, belooven niet alleen elck voor haer sellven dit contract te onderhouden maer ook te bevorderen, dat het bij [anderen] onderhouden worde, de contraventeurs te straffen ende den Gouvern ${ }^{\mathrm{r}}$ jnt straffen

1 Van der Chijs, Banda-eilanden, bldz. 181, heeft hier: „vant voors. eyland poulo-Ron op de voors. eylanden Banda ende Rossingeyn comen."

2 Sampan: inlandsch vaartuig.

7• Volgr. III. 
behulpigh te wesen naer gelegenth ${ }^{t}$ des tijts. Alldus gecontracteerdt en beslooten op 't eylandt Nera int fordt Nassouw den lesten April 1617. 1

\section{AMBON.}

16 Mei 1617. 2

De gouverneur van Ambon, Bloeq, bezocht in 1617 de Oeliasers en trad daar bemiddelend op tusschen de bewoners dier eilanden en die van sommige dorpen van Cerams Zuidkust. Het gevolg is onderstaand contract geweest. (Tiele, Bouwstoffen, I, bldz. 200, v.; Europeërs, VIII, bldz. 192).

Op huyden den XVI May a ${ }^{\circ} 1617$ sijn op de strande van Hattuwa ${ }^{3}$ vergaedert geweest de heer Adriaen Block Martensz, Gouuerneur over de landen en forten van Amboyna, met meest alle de overste vande landen ende steden onder tvoorsz. Gouvernement resorterende ten eenre, ende de hooffden ende principaelen van Cameryen, Chijcholaly, Loemekay, Lato, Holooy, Hatesyly, Aissouly, Macrica, Amahee ende Saoucon, ${ }^{+}$alle gelegen aende custe van Seram ter andere sijde, en is geacordeert ende beslooten tgeene hier nae volght en dat in presentie van de oeversten van Iha en Mau 5 die int selve accort mede sijn begrepen.

Eerstelijck sijn bij den voorsz. Gouuerneur, met hulpe vande boven gemelde vergaderinghe, ter neder geleyt alle alsulcke questien en geschil als deene stad iegens daendere vande voorsz. plaetsen, soo wel aende custe van Seram als op d' eylanden van Amboyna geleegen, hebben gehadt, met expresse conditie dat alle de parsoonen laest gerooft bij die van Oman, ${ }^{6}$ Hatuwa, eu Camerien op die van Amahee, weder sullen worden gelevert, gelijck oock die van Amahee wederomme sullen leveren alsulcke geuangen als zij van die van Oman

1 Tiele, Europeërs, vili, bldz. 197, spreekt van 4 Mei 1617.

2 Overgenomen uit Tiele, Bouwstoffen, I, bldz. 204-206.

s Hatoeaha op Haroekoe.

4 Kamarian, Tihoelale, Roemakai, Latoe, Hoewaloi, Makariki, Amahei, Sooehoekoe, allen op Cerams Zuidkust.

${ }^{5}$ Ihamaoe op Saparoea.

${ }^{6}$ Oma? 
bij haer noch hebben; dat oock mede die van Sorresorrij ${ }^{1}$ sullen weder geven een geuangen, die sij noch hebben van Cameryen, waermede alle voorgaende questien sullen doot ende te niet wezen en sullen partijen hier mede sijn en blijuen goede vrinden ende gebuiren.

Voorder is tusschen de voorsz. steden vande Custe ende den Gounerneur geaccordeert en beslooten, dat voortaen tusscheu de selve steden ende alle de steden en dorpen staande oudert gebiet vant casteel Amboina, sal sijn ende blijven eene vaste ende onverbreeckelijcke vreede te water ende te lande, sonder malcanderen in eenigher manieren meer te mogen beorlogen, bevechten, beschadigen ofte berouen tzij door haer selven ofte deur andere.

Die vande Custe van Seran welcke in dit contract begrepen zijn, en sullen niet meer vermeugen eenighe hulpe te doen aen de Alfoeris om de selue van landt te helpen, met prauwen ofte andere gelegentheyt, daer deur sij souden mogen comen aende landen en steden die onder 't Casteel staen, ende soo iemant hem hier inne te buyten gingh sal alsulcke straffe lijden als hem bij de Gounerneur sal werden opgeleyt.

Ende oft het gebeurde dat den Gouuerneur vant Casteel van eenighe vijanden, oft andere quaetaerdighe ende moetwilligge onderdaenen, yets ouer quam, en hij op sodanighe luyden haer landt wilde seynden eenighe Alfoeres, ${ }^{2}$ sullen de voorsz. steden vande Custe gehouden sijn, gelijck sij belooft hebben, den Gouverneur de handt te bieden ende hulpe te doen, dat eenighe Alfoeres tot zijnnen dienste mach becomen.

Die van Hatesily, Aissouly, Macrica, Amahee en Savoucou, verclaert hebbende datse mede zijn onderdaenen vant Casteel, gelijck se sulcx met verscheyden diensten, gedaen ten tijde vande Portugeesen, hebben bethoont, sijn bij den Gouuerneur als vassalen van den Coninck $^{3}$ van Hollandt erkent ende aengenomen onder sijne protectie ende bescherminghe, ende heeft belooft haer lieden oock te geven de vlagge vanden Coninck van Hollandt, midts dat zij lieden haer in alles sullen laeten vinden dienstwillich, gelijck die van Uliasser en andere onderdaenen von den voors. Coninck van Hollandt schuldich en gehouden zijn te doen.

1 Sirisori op Saparoea.

2 De gouverneur Blocq wilde de knoppensnellende Alfoeren in dienst der Compagnie gebruiken in eventueelen strijd met andere inlanders van deze kwartieren. (Tiele, Europëers, VIII, bldz. 191.)

s Sic! 
Aangaende de voorsz. andere steden van de Custe, al ist dat de zelue geen vassalen vant Casteel en zijn, sullen nochtants uyt crachte van dit contract, niet minder als alle de onderdanen vant casteel, bij den Gouverneur gehouden werden onder de bescherminghe van den Coninck van Hollandt, mits dat de zelve steden hen sullen laten vinden bereyt tot alsulcke diensten als de voorsz. vassalen gehouden zijn te doen, ende hun laeten gebruycken.

Item off het gebeurde dat tusschen eenighe steden van de eylanden ofte vande custe, die in dit contract zijn begrepen, eenighe questie ontstonde, het sij Oulisiva ofte Oulilima, sullen de geene die geoffenceert zijn, hunne clachten doen aenden geenen, die van wegen den Gouverneur vant Casteel sal resideren in Uliasser, den welcken tot hem sal roepen de hooffden en principaelen van de naeste steden, ende sullen tsamen hun beste doen om partijen te vereenigen, ende soo haere questie soo groot waer, dat de selve niet gevougelijck van hier en conde ter neder geleyt werden, sal als dan de selve gebracht werden voor den Gounerneur om deselve bij hem ende den geenen die hij daerouer roepen sal, affgedaen ende beslecht te werden.

Geene van alle steden in des. contracte begrepen en sullen vermogen noch om oude noch om nieuwe querellen de wapenen aen te neemen, ende malcanderen te bevechten, ende ofte yemandt hem verstoute sulckx te doen, sal den Gouverneur met de Oulisives ende Oulilimes gesamender handt op alsulcker moetwilligen stadt ofte dorp vallen, ende deselue verdestrueeren ende geheel uytroeyen.

Alle welcke articulen bij de voorgemelde vergaderinghe geacht ende beuonden zijn te weesen zeer dienstelijck ende oorbaerlijck als streckende tot eenicheyt ende rust vande landen, steden ende inwoonders vant voors. geweste, ende hebben derhaluen op de Ambonse wijse dit selue contract alsoo te onderhouden solemnelijck beswooren, gelijck oock den Gouverneur van zijne zijde belooft heeft tot onderhout desselfs hem getrouwelijcken te quijten.

Aldus gedaen ter plaetse ende dach voors. ter presentie van Sr. Jan Steyns ondercoopman vant schip d'Eendracht ende Gerret Westerman, ${ }^{1}$ sergeant, die als getuygen in dese handelinghe daerover ende bij sijn geweest, ende dit contract toirconde van dien neffens den Gouverneur hebben onderteeckent.

'Deze Westerman was door Blocq aangesteld om hem „inde eylanden" te vertegenwoordigen. (Tiele, Bouwstoffen, I, bldz. 201). 